Steve G. C. Gaspersz

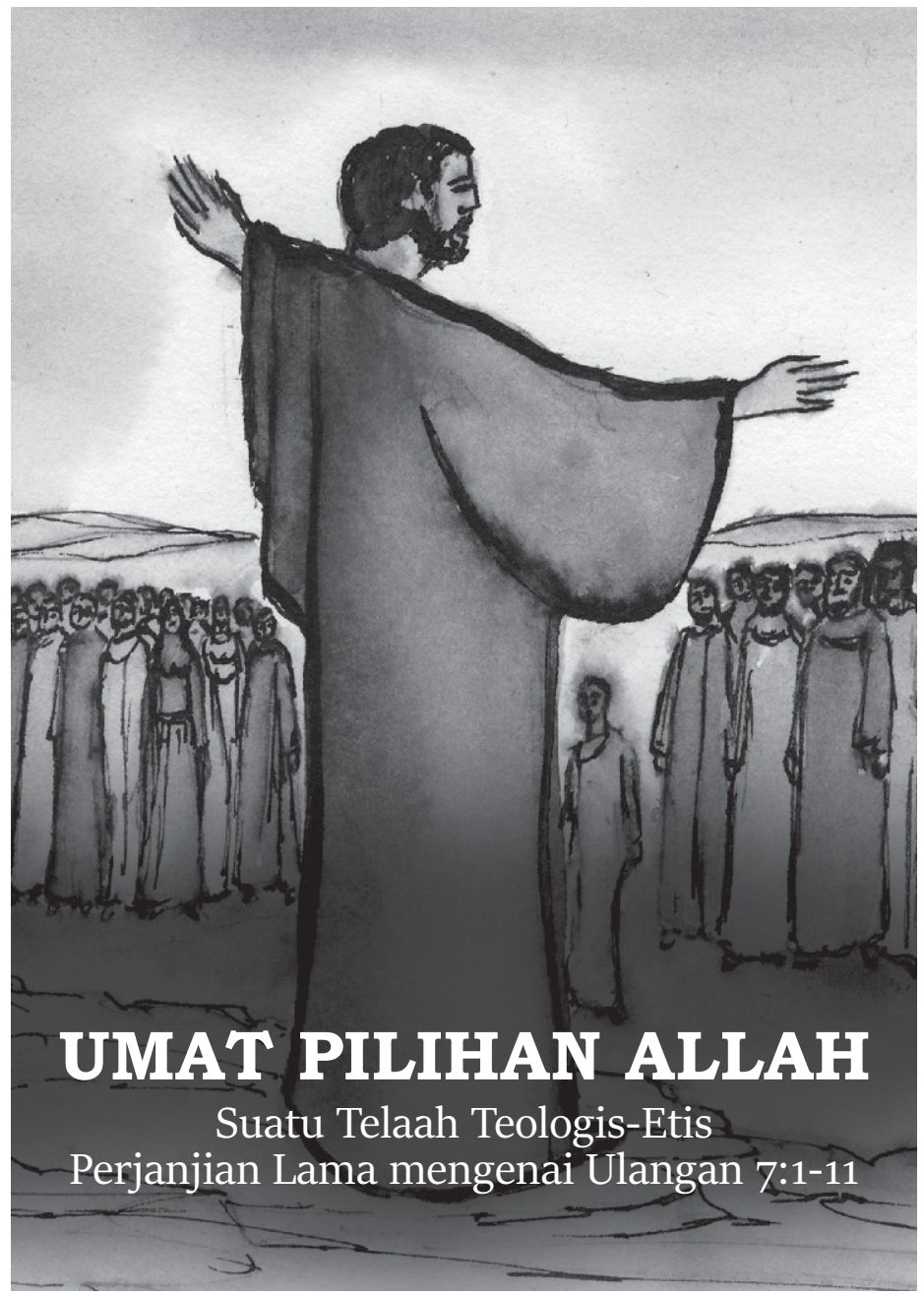

a anseniti 


\section{UMAT PILIHAN ALLAH}

Suatu Telaah Teologis-Etis Perjanjian Lama mengenai Ulangan 7:1-11

Oleh: Steve G. C. Gaspersz

190021

(C)Aseni 2019

\section{tosenseni}

Penerbit Aseni (Anggota IKAPI Pusat)

Jl. Mambruk, RT 025,

Kelurahan Kwamki, Mimika Baru, Papua, Indonesia

Telp. 08773849 2767, 082238278001

Website: www.penerbitaseni.com

Email: office@penerbitaseni.com

Desain sampul: Mischa Sekarpandya

Tata letak: Gabriel Pratamayudha

\section{ISBN 978-623-7185-12-3}

\section{Hak cipta dilindungi undang-undang.}

Dilarang keras menerjemahkan, memfotokopi atau memperbanyak sebagian atau seluruh isi buku ini dalam bentuk dan dengan cara apa pun tanpa izin tertulis dari penerbit. 


\section{Pengantar}

ahirnya sebuah karya selalu dimulai oleh titik picu tertentu, _yang kemudian secara konsisten dan bertahap menginspirasi lahirnya karya-karya berikut. Demikian pula dengan buku kecil ini. Inspirasi pertama gagasan-gagasan yang mengalir dalam buku ini bermula dari interaksi dalam proses studi pada Fakultas Teologi UKIM bertahun-tahun lampau, khususnya ketika mengikuti matakuliah "Agama dan Masyarakat" yang diasuh oleh guru saya, Dr. John Ruhulessin, M.Si. Melalui proses pembelajaran yang interaktif-kritis, kami digiring memasuki suatu arena dialektika ilmu-ilmu sosial dalam meneropong fenomena keberagamaan manusia. Pengenalan terhadap realitas sosial-budaya keberagamaan manusia melalui tugas-tugas bacaan kuliah dan diskusi-diskusi di dalam klas telah membentuk suatu cara pandang baru bagi saya, terutama dalam upaya memahami realitas pluralitas agama-agama dan konstruksi berteologi dalam agama-agama khususnya teologi Kristen.

Selain John Ruhulessin, minat awal studi saya pada waktu itu terarah pada studi biblika. Untuk hal itu, Dr. Arnold Nicholas Radjawane telah berperan besar membangkitkan minat saya pada studi biblika, terutama studi Perjanjian Lama (PL). Penguasaannya yang luar biasa dalam Bahasa Ibrani dan Hermeneutika PL telah mendorong saya untuk mendalami studi biblika PL. Sayangnya, harapan itu pupus ketika saya mengajukan proposal skripsi dengan 
topik seputar kajian biblika PL. Pasalnya, waktu itu tidak satu pun dosen biblika PL pada Fakultas Teologi UKIM: Dr. A. N. Radjawane sedang menjadi dosen tamu di Fiji; Ibu Margaretha RirimasseHendriks dan Bapak Jafet Damamain sedang menempuh studi doktoralnya. Keputusan rapat dosen meminta saya mengganti perspektif keilmuan (tidak lagi ke biblika). Maka kemudian saya mengarahkannya menjadi etika PL di bawah bimbingan Bapak E. P. Kaihena, M.Th.

Kegelisahan dialektis antara konseptualisasi berbagai pandangan teologis, interpretasi tekstual terhadap kitab keagamaan Kristen (Alkitab) dan realitas pluralisme sosial-budaya suatu masyarakat, telah mengantarkan saya memasuki diskusi-diskusi kepustakaan yang intens untuk mencari hubungan-hubungan logis-konseptual ketiga kutub tersebut. Konseptualisasi teologis terbentuk melalui pengalaman menggereja dalam suatu kenyataan bermasyarakat sebagai bagian integral dari entitas negara (Indonesia). Konseptualisasi teologis itu juga pada hakikatnya berakar dalam geliat memaknai teks-teks Alkitab yang hampir sebagian besar tidak dapat terpahami secara harfiah sebab merupakan produk ruang dan waktu yang membentang jarak epistemik nan jauh dan dalam, dan oleh karenanya membutuhkan penelusuran hermeneutik dengan berbagai perangkat analisis kebahasaan (Yunani dan Ibrani) dan konteks alkitabiah (sociological exegetic). Kedua kutub epistemik tersebut kemudian diperhadapkan dengan arena eksplorasi kenyataan sosial-budaya kontemporer yang perlu dimaknai secara korelatif antara "teks" dan "konteks" sehingga apa yang disebut sebagai refleksi teologis itu pun tidak hanya berkelana pada ruang-ruang abstrak tapi mampu menggumuli pula ranah-ranah empirik sebagai realitas yang dihidupi dan dimaknai terus-menerus.

Kendati dinarasikan sebagai refleksi akademik seorang mahasiswa pada akhir era 1990-an, yang jelas jauh berbeda dengan realitas transformasi sosial terutama pasca 1998-an di Indonesia, namun membaca kembali alur pemikirannya maka masih terasa impuls- 
impuls kegelisahan yang hingga kini tetap menjadi pergulatan Kristianitas dalam relasinya dengan eksistensi agama-agama dan realitas sosial-budaya Indonesia yang berkelindan dengan keragaman identitas yang menghidupkan keindonesiaan itu sendiri. Pada batasan tertentu, sebagai suatu karya yang diproduksi pada ruang dan waktu di masa lampau banyak bagian yang perlu ditinjau kembali dan dimutakhirkan. Namun, saya mencoba mempertahankan orisinalitasnya hingga sejauh batasbatas penalaran yang dapat dipertanggungjawabkan. Yang terlebih penting, sebagai penulisnya, saya memang menampilkan suatu jejak trajektoris peziarahan intelektual saya sebagai kritik terhadap bangunan ide yang pernah saya susun dan yang di atasnya saya mencoba secara konsisten mengembangkannya hingga kini. Dengan demikian, saya tidak berpretensi memolesnya sedemikian rupa hingga spiritualitas akademik yang pernah menggairahkan saya pada waktu lampau kemudian sirna begitu saja hanya atas nama pemutakhiran gagasan. Saya ingin mengawetkannya sebagai sebuah monumen akademik yang dengannya selalu membawa saya pada tapak-tapak waktu yang pernah saya tapaki dengan jerih-lelah.

Rasanya, saya juga perlu "berterima-kasih" kepada rayaprayap yang sempat menggerogoti belasan koleksi buku pribadi saya pada suatu waktu. Skripsi ini salah satunya. Mungkin jika tidak demikian, tak pernah terbersit niat yang serius untuk menjaganya sebagai sebuah karya jerih-lelah yang berharga dan mesti diawetkan dalam bentuk buku. Namun, ternyata mimpi untuk mewujudkannya menjadi buku kerap dibuyarkan oleh kesibukan bekerja dan rutinitas-rutinitas lainnya yang menjejali waktu-waktu menjalani kehidupan. Puluhan tahun naskah ini mengendap dan nyaris dihabisi oleh rayap. Ketika menemukannya kembali saat menata koleksi buku-buku pribadi, sontak mimpi yang dulu meredup menampakkan pendar kecilnya. Pendar cahaya itu pun makin besar ketika secara bertahap saya mulai menyalinnya kembali menjadi file pada laptop. Maklum, 
saya menggarap skripsi dulu masih dengan menggunakan mesin tik manual merek brother. Lagi-lagi, karena tumpukan pekerjaan yang kian tinggi dan padat, penyalinannya sempat terhenti namun pendar cahaya mimpinya tidak lagi meredup. Oleh karenanya saya berterima kasih kepada mahasiswa saya, Fresly Risakotta, yang membantu saya menyelesaikan pekerjaan penyalinan naskah skripsi tersebut sehingga dapat dilanjutkan ke tahap pencetakan dan penerbitannya.

Minat pada kajian agama dan masyarakat ini tumbuh pada masamasa ketika dialog antaragama menjadi isu yang mengarusutama pada era pertengahan 1990-an. Di lingkungan Kristen kerap digelar diskusi dan seminar seputar isu itu kendati mesti diakui masih lebih banyak berputar pada ranah-ranah perjumpaan yang sangat formal dan elitis. Sebelum tahun 1998, ada beberapa peristiwa ketegangan antarkelompok agama dan tindakantindakan yang mengarah pada intoleransi beragama di Indonesia. Namun, peristiwa-peristiwa tersebut mampu diredam oleh pendekatan keamanan negara Orde Baru - yang oleh pihak-pihak tertentu dinilai represif - sehingga tidak meledak menjadi konflik berskala besar. Konteks itu melatari minat saya untuk menelusuri hal-ihwal dialog antaragama di Indonesia dengan semua potensi peluang dan tantangannya baik secara internal maupun eksternal.

Salah satu yang mengusik dan membangkitkan minat dalam hal itu adalah narasi Kitab Ulangan 7:1-11. Pada bacaan sepintas terhadap teks itu saya merasakan pesan eksklusivisme keagamaan dan sikap peyoratif-triumfalistik terhadap liyan. Saya mencoba membayangkan saat itu bagaimana suasana batin yang dirasakan ketika membaca teks semacam ini di antara "keriuhan" wacana dialog antaragama yang sedang dibergema di mana-mana. Tidak hanya itu. Dalam kegairahan dialog antaragama pada masa itu teks-teks keagamaan semacam ini sering "disembunyikan" atas nama toleransi ketika sedang berada bersama-sama, namun dalam lingkungan internal keagamaan sendiri teks-teks semacam itu malah menjadi amunisi yang menghidupkan perspektif 
fundamentalisme dan fanatisme keagamaan yang membentuk kesadaran keagamaan yang bermuka-dua (munafik). Tidak mudah mengatasi situasi dilematis itu: pada satu sisi, mendaku kebenaran transendental yang berakar pada keyakinan akan sakralitas teks-teks keagamaan sebagai "Firman Tuhan"; pada sisi lain, berhadapan dengan eksistensi kelompok-kelompok keagamaan lain yang juga mendaku kebenarannya sendiri dan hidup bersama dengan seluruh pendakuan kebenaran tersebut. Lebih jauh, kajian sederhana mengenai teks Ulangan 7:1-11 tersebut tidak semata-mata dilihat sebagai suatu teks yang berdiri sendiri tetapi juga hendak dilihat implikasi etisnya dalam perspektif dan praksis hidup bersama dengan berbagai perbedaan (termasuk perbedaan agama-agama). Implikasi etis dari suatu pembacaan terhadap teks-teks keagamaan merupakan upaya untuk menjembatani konteks produksi teks-teks tersebut dengan konteks para pembaca masa kini yang mereproduksi teks-teks keagamaan tersebut dengan pemaknaan-pemaknaan mutakhir (terbaru) sesuai dengan realitas kekinian yang dihidupi. Dengan demikian, teks-teks keagamaan itu tetap hidup dan terus dihidupi karena diyakini mempunyai daya mengarahkan sikap dan perilaku keagamaan melalui pertimbangan-pertimbangan apa yang seharusnya dilakukan dalam situasi kehidupan yang spesifik.

Dalam relasi keberagamaan berbagai kelompok agama, implikasi etis keyakinan beragama merupakan faktor determinan menjaga keseimbangan sosial dimana setiap individu/kelompok merasa diterima oleh liyan sekaligus turut bertanggung jawab menerima liyan. Dengan perkataan lain, implikasi etis terutama dari interpretasi atau reproduksi makna teks-teks keagamaan hanya dapat didaku kebenarannya secara relasional dengan liyan relational faith. Iman yang terbangun secara relasional. Sebagai yang demikian, maka beriman adalah suatu proses pencarian dan peziarahan kehidupan yang berlangsung dinamis, dialektis dan fluktuatif. Beriman dan/atau beragama yang relasional itu pun menolak untuk dijerat oleh kejumudan tekstual dari berbagai 
pernyataan absolutisme dalam kitab-kitab keagamaan. Sebaliknya, terus-menerus berupaya untuk melampaui keterbatasan tekstual untuk menggapai tahapan-tahapan kontekstual sebagai hasil dari dialog teks-konteks yang kreatif-kritis. Pernyataan-pernyataan keimanan untuk memaknai identitas secara teologis, yang dalam buku ini disebut sebagai identifikasi "Umat Pilihan Allah", meski secara in-group dimaknai sebagai basis identitas teologis, namun pada ranah out-group identifikasi itu ditantang untuk terbuka dalam relasi dengan liyan. Oleh karena itu, proses dekonstruksi tekstual itu pun menjadi keniscayaan karena relasi dengan liyan adalah panggilan etika keberagamaan semesta.

Buku ini hanyalah refleksi kecil mengenai relational faith dengan seluruh ketegangan identitas yang menyertai ekspresi beriman atau beragama dari kelompok-kelompok agama yang hidup bersamasama dalam entitas negara yang majemuk masyarakatnya. Sebuah pantulan kegelisahan beriman, yang digumuli 6 tahun sebelum pecah konflik sosial yang menunggangi isu agama di Maluku tahun 1999-2005. Berbagai perspektif sosiologis agama dan refleksi-refleksi teologis pun diwacanakan sepanjang dan pasca tragedi kemanusiaan tersebut. Pada momentum itulah, buku ini hendak menjadi catatan kecil yang mengingatkan diri sendiri bahwa peziarahan beriman dalam konteks masyarakat majemuk di Indonesia, bahkan dalam konteks internasional, tidak akan pernah berhenti pada satu titik final kebenaran transendental yang absolut. Ia selalu bergerak membangun kanal-kanal komunikasi dan relasi yang kreatif-kritis serta menghidupkan berhadapan dengan kemungkinan-kemungkinan meruntuhkan martabat kemanusiaan semesta.

Secara konseptual dan metodologis, kajian sederhana dalam buku ini memiliki banyak keterbatasan informasi mutakhir. Studibiblika, etika dan teologi agama-agama telah mengalami perkembangan yang luar biasa. Tujuan utamanya adalah menempatkan salah satu "batu bata" kajian teks keagamaan, interpretasi teologis dan etika sosial dalam satu jaringan epistemik yang saling mengkritik dan 
saling menyumbang menanggapi realitas kehidupan yang dijalani oleh para pelaku beragama, yang dalam hal ini difokuskan pada Kristianitas dan orang Kristen. Apa yang dicita-citakan melalui publikasi buku kecil hanyalah agar ada rangsangan-rangsangan intelektual untuk melakukan studi lebih lanjut dan lebih mendalam oleh generasi pelaku beragama (Kristen) dan/atau pembelajar teologi selanjutnya. Itu saja. Dari situ jelas bahwa buku ini pada hakekatnya terbuka untuk dikritik melalui perluasan cakrawala berteologi yang lebih kritis dan mutakhir. Semoga.

Steve Gaspersz Ambon, November 2019 


\section{Daftar Isi}

Pengantar

Bab 1

Pluralisme Beragama:

Mencari Keseimbangan Pijakan Teologis $\quad 11$

1. Dasar Pijak 11

2. Telisik Pustaka 19

Catatan Akhir: $\quad 24$

Bab 2

Telisik Kitab Ulangan 7:1-11 27

1. Konteks Umum Kitab Ulangan 27

2. Konteks Khusus Ulangan 7:1-11 32

3. Teologi Kitab Ulangan 36

4. Tafsiran Ulangan 7:1-11 43

5. Paradigma Umat Pilihan Allah dalam Ulangan 7:1-11 63

Catatan Akhir: 67

Bab 3

Panggilan Teologis-Etis Umat Pilihan Allah 69

1. Pengantar 69

2. Umat Pilihan Allah dalam Pluralisme Beragama 71

3. Fundamentalisme: Suatu Identitas Alternatif? 79

4. Umat Pilihan Allah dan Transformasi Sosial 82

Catatan Akhir: $\quad 89$

Bab 4

$\begin{array}{ll}\text { Simpul } & 91\end{array}$

Kepustakaan $\quad 95$

$\begin{array}{ll}\text { Tentang Penulis } & 101\end{array}$ 


\section{Bab 1 \\ Pluralisme Beragama: \\ Mencari Keseimbangan Pijakan Teologis}

\section{Dasar Pijak}

ereja dalam artinya sebagai persekutuan orang percaya pada

7 hakekatnya melandaskan iman di atas keyakinan bahwa dirinya merupakan persekutuan orang-orang atau umat yang dipilih Allah. Gereja ada sebab Yesus memanggil mereka menjadi pengiring-Nya dan masuk dalam persekutuan selaku murid-murid bersama-sama dengan Dia. Jadi wujud gereja, pertama-tama, ialah persekutuan dengan Kristus; tetapi dalam persekutuan dengan Kristus tersebut gereja juga terlibat dalam hidup persekutuan dengan orang lain yang turut merasa terpanggil.

Di dalam wujudnya selaku persekutuan (dengan Kristus, sesama manusia dan lingkungan hidup), Gereja mengemban suatu tanggung jawab yang sangat esensial. Tanggung jawab yang pada dirinya tidak terlepas dari wujud gereja itu sendiri, yakni memberitakan Injil: "Karena itu pergilah, jadikanlah semua bangsa murid-Ku" (Mat. 28:19). Dengan lain perkataan, gereja dan pemberitaan Injil itu merupakan dua substansi yang pada hakekatnya satu (dwitunggal ) dan tidak terpisahkan. ${ }^{1}$

Dengan demikian, di dalam hakekat dan wujudnya gereja tidak lagi hidup bagi dirinya sendiri tetapi juga terpanggil untuk 
membagikan kesaksian hidup persekutuan dan kasihnya dengan Kristus kepada orang lain. Keterpanggilan ini tidaklah bergantung pada keinginan dan perasaan suka atau tidak suka tetapi sematamata didorong oleh anugerah Allah yang menggetarkan dan menggerakkan gereja menjadi alat shalom Allah bagi liyan. Sehingga mereka pun turut mengambil bagian merasakan kasih dan keselamatan dari Allah.

Melalui bingkai keterpanggilannya dan realitas sosio-historisnya dalam berteologi melintasi berbagai ruang dan waktu, Gereja makin menyadari bahwa ia mengada dan bertumbuh di tengah situasi kontekstual kemanusiaan dan sejarah dunia. Sekecil apapun peranannya, kehadiran Gereja secara etis-teologis tetap memberikan warna dan corak tersendiri di atas panggung sejarah dunia. Pun sebaliknya, konteks dan suasana sekitaran di mana Gereja hadir, bergerak dan berkarya turut memberikan nuansa-nuansa baru dalam dalam seluruh dimensi pemaknaan eksistensinya, serta implementasi gerak dan aksinya. Dengan demikian, Gereja yang hidup itu adalah gereja yang berakar di dalam dan kritis terhadap konteks. Dalam tolehan yang kritis terhadap konteks itu maka kita mencermati bahwa pluralisme masyarakat merupakan suatu realitas kemasyarakatan yang terus berproses menjadi berbagai fenomena dan fakta sosial dengan segala kekuatan, tantangan dan ancamannya.

Seorang teolog Indonesia, J. Garang, menanggapi kemajemukan masyarakat Indonesia sebagai kenyataan objektif dan kemajemukan sosial budayanya merupakan konsekuensi logis dari perjalanan panjang sejarah negara-bangsa ini, baik secara etnologis maupun antropologis, termasuk pada berbagai matra keberagamaan dan kepercayaan yang ada. ${ }^{2}$ Di dalam konteks inilah gereja-gereja di Indonesia hadir untuk menyatakan hakekat dan wujudnya selaku umat Allah, serta ditantang untuk tegar mandiri menghadapi hempasan ombak zaman yang keras menghantam tak terbendung. 
Berhadapan dengan konteks pluralisme masyarakat semacam Indonesia itu maka Gereja, yang secara eksklusif-teologis meyakini eksistensi dan misinya selaku umat Allah, juga ditantang oleh realitas krisis identitas. Suatu krisis yang bila tidak segera diantisipasi sebagai suatu dinamika dari proses pembentukan jatidiri malah justru nanti pada gilirannya makin membawa Gereja pada kemandegan dan impotensi. Padahal ikhtiar pemantapan jatidiri selaku umat Allah mesti ditempa terus-menerus dalam dinamika zaman dan konteksnya baik secara individual maupun kolektif.

Pada konteks itu, maka terdapat dua dimensi yang patut diamati dengan saksama: [1] Dimensi Teologis. Pada dimensi ini Gereja selaku umat Allah bernafas dalam suatu atmosfer teologis yang memberinya "hawa segar" kehidupan dan ketahanan untuk bertumbuh sepanjang sejarah. Dalam lingkup atmosfer konteks sosio-budayanya Gereja hidup dengan suatu tanggung jawab selaku umat Allah, komunitas kristiani yang terpilih dan terpanggil untuk memberitakan shalom dan kabar kesukaan (Injil) kepada setiap orang. Tanggung jawab ini bersifat non-negotiable atau tidak dapat ditawar-tawar. [2] Dimensi Etis. Sejarah menunjukkan bahwa dalam pergumulan mengemban tanggung jawab misioner tersebut ternyata Gereja tidak luput dari jatuhbangunnya, bahkan kerap terperangkap dalam pusaran arus idealisme-idealisme sekular yang dilatari oleh rasa superioritas dan kemapanan kekuasaan atas kehidupan rohani komunitasnya sendiri (jemaat) yang merembes dalam tendensi yang kuat untuk juga mendominasi dan menghegemoni kehidupan sosial, politik, budaya dan ekonomi komunitasnya (warga gereja).

Ihwal ini kemudian terpancar keluar dalam percikan-percikan semangat misioner yang berlebihan dan triumfalistik. Semangat misi yang mestinya melandasi komunitas kristiani guna membangun kehidupan menuju pembebasan karena anugerah dari Allah kini sebaliknya menyeret umat terasing dari konteksnya. Mengapa demikian? Tidak lain karena di dalam semangat misi 
yang berlebihan dan over-acting ini kerap mengabaikan banyak hal atau faktor, seperti kebudayaan, pola-pola berpikir tradisional yang masih kokoh dipegang dan nilai-nilai eksistensial yang menjadi pedoman dalam penentuan kehidupan etik-spiritual suatu masyarakat. Selanjutnya, malah cenderung untuk secara radikal menggantikannya dengan nilai-nilai yang [dianggap] "baru", serta lebih "rohani" dan "kristiani"

Dalam pijaran semangat misi yang menyala-nyala inilah konsepsi umat pilihan Allah kembali dimunculkan tetapi dalam coraknya yang lain, yaitu melalui konsepsi God's Chosen People atau "Umat Pilihan Allah" yang dimanifestasikan dalam bentuk gerakan purifikasi (pemurnian) nilai-nilai alkitabiah secara harfiah, seperti fundamentalisme atau sikap beragama yang fundamentalistik (menjurus pada fanatisme agama yang sempit).

Kendati pada prinsipnya tujuan semacam itu secara internal bisa dilihat sebagai sesuatu yang luhur dan sah-sah saja, namun dalam ekspresi sikap beragama hal itu lebih tampak sebagai luapan frustasi-frustasi akan gencarnya nilai-nilai kontemporer modernitas yang menggempur setiap sendi kehidupan manusia, termasuk komunitas-komunitas beragama. Reaksi terhadap modernitas dan sekularisme - yang turut ditopang oleh perkembangan teknologi informasi-komunikasi yang kian canggih - pada tataran internal keberagamaan Kristen mewujud dalam tendensi membangun "benteng pertahanan" dengan mengekspresikan kembali posisi dan identitas sebagai umat pilihan Allah dalam dimensi dan ekspresi beragama yang eksklusif, arogan dan introver.

Dalam konteks pluralisme agama, Harold Coward menyatakan terbentuknya polarisasi pemahaman dan sikap beragama - dalam hal ini Kristen - yang, pada satu sisi, mendorong orang-orang Kristen menilai kembali dengan serius pemahaman mereka mengenai kehendak Allah, ajaran alkitabiah mengenai Yesus, Trinitas, soteriologi (ajaran keselamatan) dan sebagainya. 
Sedangkan pada sisi lain, konteks modernitas dan sekulerisme itu juga mendorong komunitas Kristen untuk mengisolasi diri dalam suatu kerangka berteologi yang eksklusif dan triumfalistik, yaitu identifikasi diri secara teologis-ideologis sebagai umat Allah yang dipilih khusus - dengan pendasaran tekstual pada Kitab Ulangan 7:6 - yang pada gilirannya merupakan tanah subur yang melahirkan sikap beriman dan perilaku beragama yang jumud serta mendorong aktivitas-aktivitas "misioner" yang arogan dan massif tanpa mengindahkan realitas sosial-budaya dalam kehidupan bersama identitas-identitas liyan. ${ }^{3}$

Era akhir abad ke-20 dan awal abad ke-21 ditandai dengan berbagai perubahan dan fenomena sosial-politik kemasyarakatan, serta kemajuan teknologi yang luar biasa hebat dan pesat. Modernisasi, perkembangan rasionalisasi kehidupan manusia yang menakjubkan dan globalisasi informasi-komunikasi yang super-canggih telah menciutkan dunia dan alam semesta seolah satu desa kecil (global village). Globalisasi juga mendobrak batas-batas primordial yang selama ini menghalangi manusia untuk saling berkomunikasi melintasi sekat-sekat identitas dan tanpa ikatan apapun, serta membuka peluang bagi terciptanya interaksi dan interkoneksi nilai-nilai, ide-ide dan praktik-praktik kehidupan bermasyarakat yang makin kompleks.

Bersamaan dengan itu pula, sebagaimana pernah dinyatakan oleh John Naisbitt, bahwa gaya hidup global menjalani garis tipis antara pilihan yang lebih luas dan homogenisasi yang lebih besar, yang kian mengurangi pilihan-pilihan kehidupan umat manusia di bumi. ${ }^{4}$ Gaya hidup umat manusia cenderung berkembang makin homogen sebagai suatu trend, sementara di sebelah lain muncul suatu fenomena counter-trend yang kian menguat: serangan balik terhadap keseragaman, suatu hasrat untuk menegaskan keunikan kultur dan bahasa, penolakan terhadap hal-hal yang dianggap terkontaminasi pengaruh asing atau apa yang disebut Naisbitt dengan "Nasionalisme Kultural". ${ }^{5}$ Dengan lain perkataan, berhadapan dengan tendensi homogenisasi yang 
terus berkembang, Naisbitt menegaskan bahwa kita semua akan berusaha melestarikan identitas kita, apakah itu agama, kultur, kebangsaan, bahasa atau ras. ${ }^{6}$

Prediksi Naisbitt tersebut mengisyaratkan bahwa di tengah kompleksitas perkembangan fenomena kemasyarakatan, yang disertai pula dengan semangat hidup global dengan tendensi penonjolan rasionalitas yang sangat tajam, institusi-institusi keagamaan ditantang untuk mewaspadai setiap perubahan yang dicurigai sebagai penetrasi nilai-nilai dan ide-ide modernitas dan sekularisme yang bermuara pada pemakluman akan suatu sikap hidup beragama yang liberal dan sekuler. Suatu fenomena global yang dianggap mengancam eksistensi keberagamaan dan menggerus identitas agama-agama yang berpijak kuat pada fondasi-fondasi dogmatis keagamaan. Gencarnya arus-arus liberalisme, sekularisme, modernisasi dan globalisasi baik dari dalam maupun dari luar ini memaksa institusi-institusi keagamaan untuk berupaya ekstra keras membentengi dirinya agar nilai-nilai transendental yang diimaninya tidak tergerus arus.

Jadi, ada semacam ikhtiar pengokohan identitas di tengah prosesproses sosial-politik dan kebudayaan yang kompleks dan dinamis. Perjuangan mencari dan mengukuhkan identitas-identitas primordial (etnisitas dan keagamaan) ini pada gilirannya menggairahkan semangat fundamentalisme dalam berbagai ajaran dan praktik keberagamaan di dunia. Semangat yang sangat antusias menolak segala bentuk perubahan yang dicurigai akan mempengaruhi kemurnian nilai-nilai ajaran atau doktrin agamanya. Kendati penolakan semacam itu lebih berwujud instrumentalis dan simbolis karena hanya terjadi pada tataran praktis saja. Namun, secara prinsipil sebenarnya sulit untuk menghindari perubahan-perubahan yang terjadi secara subtil pada semua agama.

Akan tetapi, tidak jarang di sebelah lain, semangat ini membawa institusi-institusi agama, dalam hal ini Gereja, terperangkap 
dalam absolutisme yang cenderung bersikap peyoratif terhadap liyan, tetapi menolak untuk dirinya dinilai dan dikritik bahkan menjadi garang bila "kebenarannya" diusik. Gereja melihat dirinya sebagai corpus christianum yang berdiri sendiri dengan wilayah kekuasaannya yang tidak boleh diganggu-gugat oleh liyan. Malah harus sebaliknya, kekuasaan dan pengaruh Gerejalah yang harus diakui dan mutlak diterima. ${ }^{7}$ Sejalan dengan itu, dengan dilatari oleh rasa superioritasnya, Gereja menginterpretasi eksistensinya sendiri di tengah konteks dan kompleksitas pluralisme sosialagama sebagai "umat pilihan Allah" dalam perspektif yang sempit dan eksklusif.

Pemahaman akan eksistensi dan identitas umat pilihan Allah ini diangkat sebagai konsekuensi logis dari munculnya berbagai macam nilai dalam masyarakat terglobalisasi (globalized society). Kendati selanjutnya pemahaman tersebut diekspresikan melalui sikap-sikap dan gagasan-gagasan yang vulgar, seperti tudingantudingan "sesat" dan "kafir" bagi liyan yang berada di luar denominasinya atau out-group Kristianitas berbasis aksioma extra ecclessiam nulla salus, lantas dilihat sebagai ancaman. Secara eksternal, dengan demikian, tidak diperlukan pretensi apapun untuk berkompromi. Sedangkan secara internal, menurut James Barr, terdapat pemahaman bahwa Alkitab adalah segalanya dan oleh karena itu harus ditafsirkan sedemikian rupa agar terhindar dari pengakuan bahwa itu mengandung kesalahan dalam bentuk apapun atau ineransi Alkitab. Segala model metode penafsiran teks-teks Alkitab yang kritis pun ditolak mentah-mentah karena dianggap telah melecehkan "Firman Tuhan".

Seorang teolog Protestan Indonesia, Eka Darmaputera, menyatakan bahwa gejala tersebut tentu saja melahirkan suatu kecenderungan yang kuat untuk mengangkat "teks" mentahmentah dan memaksanya untuk menjawab tantangan dan pergumulan di dalam "konteks" yang berubah tanpa sikap kritis memahami kerygma yang terkandung di dalamnya sebagai langkah berefleksi atas situasi problematik kontemporer. ${ }^{9}$ Itu 
berarti, upaya menggali makna konsep "umat pilihan Allah" dalam konteks masyarakat luas dan komunitas Kristen dewasa ini memiliki signifikansi yang urgen, yaitu agar konsep identitas diri ini mampu menjadi landasan teologis yang solid dari eklesiologi Kristen yang inklusif. Gereja yang terbuka terhadap pembaruan dalam konteks masyarakat majemuk.

Pluralisme agama bukanlah fenomena dan/atau fakta sosial yang aneh di Indonesia. Masyarakat nusantara pra-Indonesia telah menghidupi realitas pluralisme religiositas lokal selama ratusan tahun hingga kedatangan dan interaksi dengan masyarakat Barat. Hingga kemudian dominasi agama-agama dari luar nusantara, terutama Islam dan Kristen, makin membesar dan menguat seperti yang terjadi dalam perdebatan para pendiri republik ini pada masa-masa awal pasca-kolonial pendiriannya dan penentuan identitas nasionalnya pada tahun 1945. Mengapa fakta sosial ini belakangan - terutama pasca Gerakan Reformasi 1998 - menjadi isu panas yang mengguncang kohesi sosial masyarakat Indonesia? Eka Darmaputera secara sederhana memberikan uraian singkat yang merunut bergejolaknya hubungan agama-agama di Indonesia demikian: ${ }^{10}$

"... khususnya sejak tahun 1966, masalah tersebut muncul dalam intensitas yang melebihi waktu-waktu yang lampau... pada masa prakemerdekaan, kelompok-kelompok agama itu relatif hidup terpisah-pisah. Pada awal kemerdekaan sampai jatuhnya Orde Lama, kelompok-kelompok agama itu seolah-olah dipersatukan di dalam satu "front" menghadapi "lawan" bersama, yaitu Belanda pada awalnya dan kemudian tekanantekanan PKI. Ketiadaan "lawan" bersama, kebangkitan kesadaran identitas (dan frustrasi-frustrasi) khususnya di kalangan Islam, dampak perkembangan dunia internasional dan melonjaknya mobilitas penduduk di dalam negeri, menurut hemat saya, adalah beberapa faktor penting yang membuat masalah antaragama semakin muncul ke permukaan. Dan tentu saja harus ditambahkan di sini, praktik-praktik penginjilan yang kurang peka atau tidak mempedulikan konteks situasi yang ada."

Dari sinilah kemudian tumbuh suatu kesadaran akan identitas diri, percaya diri dan harga diri dibarengi dengan kesadaran akan ketergantungan dirinya dengan liyan. Berdasarkan 
keprihatinan di atas maka studi ini hendak menelisik [1] Apakah makna konsepsi umat pilihan Allah di dalam kerangka teologi Deuteronomi (Kitab Ulangan) pasal 7:1-11?; [2] Bagaimanakah identitasnya dalam suatu konteks kehidupan sosial sebagai masyarakat Indonesia bersama-sama dengan identitas-identitas liyan?; dan [3] Apa tanggung jawab etis Kristianitas yang secara teologis mengidentifikasi identitasnya sebagai umat pilihan Allah dalam perjumpaan dengan berbagai identitas sosial, budaya, politik dan ekonomi?

\section{Telisik Pustaka}

Ulasan ini bertumpu pada dua acuan teoretik, yakni acuan pemahaman dan analisis mengenai konsepsi "umat pilihan Allah" dalam kerangka teologi Kitab Ulangan 7:1-11 dan acuan pencari visi mengenai ikhtiar pengembangan pemikiran etis-teologis mengenai identitas dan tanggung jawab eklesiologisnya dalam konteks pluralitas keagamaan serta pemaknaannya bagi Gereja sekarang.

Guna memahami masalah, pertama-tama akan diperhatikan di sini pendapat seorang sosiolog Jerman, Max Weber, mengenai Etika Protestan. Menurut Weber, etika Protestan memperlihatkan suatu orientasi beragama yang bersifat asketik dalam dunia (inner-worldly) yang jauh lebih lengkap daripada agama besar apapun lainnya, termasuk Katolisisme. ${ }^{11} \mathrm{Apa}$ yang sesungguhnya dibutuhkan oleh seorang Protestan pada mulanya adalah suatu tanda di mana mereka yakin bahwa mereka termasuk dalam "orang pilihan", yang dipilih Allah untuk menjadi selamat. ${ }^{12}$ Dengan pekerjaan sekuler yang dianggap sebagai kewajiban agama, adalah lumrah bahwa orang-orang Protestan pada masamasa awal itu harus melihat sukses dan kesejahteraan yang dihasilkan oleh pekerjaannya sebagai tanda bahwa mereka terpilih untuk keselamatan. Bagaimanapun juga, tampaknya hampir tidak mungkin bahwa Allah akan memberkati mereka yang tidak terpilih. Dalam penguraian teorinya secara lebih luas 
ternyatalah bahwa Weber sangat menekankan ide-ide tertentu dalam Protestanisme yang memperlihatkan suatu perubahan dari tradisionalisme ke suatu orientasi yang lebih rasional. ${ }^{13}$

Dari perspektif alkitabiah dapat dikatakan bahwa salah satu konsep teologis yang sangat potensial dalam merangsang dan mendorong sikap beragama yang eksklusif apabila salah diinterpretasi ialah konsep teologis tentang "umat Allah" (Ibrani: am Yahwe), yang dipilih khusus oleh Allah dari antara umat yang lain. Menurut Gerrit Singgih, kitab Ulangan dapat dikatakan mewakili pandangan Israel sebagai umat kesayangan Allah. Secara eksplisit dapat dilihat dalam Ulangan 7:1-11. ${ }^{14}$ Khusus mengenai ayat 6 , Clements berpendapat: ${ }^{15}$

"The uniquenes of Israel is fully disclosed in the brief phrase 'a people holy to the lord your God'. What make the citizens of Israel different form the citizens of any other country is the fact that they are in a sacred relationship to Yahweh as their national God."

Konteks Ulangan 7:1-11 adalah bagaimana seharusnya bersikap terhadap orang lain. Bangsa-bangsa lain yang sudah hidup di "tanah perjanjian" sebelum kedatangan Israel harus ditumpas dan tidak boleh dikasihani (7:2). Ada konstruksi ideologi politik yang dilandasi oleh teologi keterpilihan bahwa Israel adalah umat kudus yang dipilih Tuhan sedangkan bangsa-bangsa lain tidak. Israel harus menjaga status keterpilihannya yang steril dari pengaruh bangsa-bangsa lain. Hal itu diperlihatkan dengan bersikap intoleran terhadap liyan. Itulah jalan satu-satunya atau hukum agar tidak mengulangi kesalahan mengalami pembuangan (exile) untuk kedua kalinya. ${ }^{16}$ Hukum yang dimaksud adalah hukum keagamaan sehingga sikap intoleransi tersebut lebih ditujukan kepada praktik-praktik keagamaan bangsa-bangsa lain tersebut. "Deuteronomy was not preaching a hatred of Gentile nations but a hatred of false religious teaching and practices," demikian Clements. ${ }^{17}$ 
Langkah guna memahami teologi Ulangan 7:1-11 tentu tidak dapat dilepaskan dari kerangka teologis Kitab Ulangan secara utuh di dalam konteks pembentukannya. I. J. Cairns menyatakan bahwa pada satu taraf dalam proses perkembangannya Kitab Ulangan disusun dalam struktur sebagai naskah perjanjian. Struktur itu sangat dipengaruhi oleh rumusan perjanjian antarnegara yang lazim dipakai di dunia Asia Barat Daya Kuno, khususnya perjanjian antara Maharaja dengan raja-raja taklukannya. ${ }^{18}$ Selanjutnya, selama abad ke-8 s.M., kekuasaan Kerajaan Asyur memuncak, kemudian surut selama abad ke-7. Periode ini yang menentukan dalam penyusunan Kitab Ulangan.

Berhadapan dengan kejayaan kuasa Asyur dan kemudian kemorosotannya, bangsa-bangsa jajahannya terdorong untuk meninjau kembali konsep "perjanjian Maharaja" itu. Pada masa kejayaannya, Asyur mengenakan suatu perjanjian politik terhadap raja-raja taklukkannya. Sedangkan pada masa kemorosotannya, raja-raja taklukkan mendapat kesempatan untuk menyangkal perjanjian itu. Dalam suasana politik sedemikian para tokoh Mazhab Ulangan menggunakan struktur "perjanjian Maharaja" itu sebagai suatu rangkaian gagasan teologis, supaya pemberitaan mereka lebih mengena kepada Israel sebagai satu bangsa yang berada di tengah pergolakan politik saat itu. Aksentuasi teologi mereka ialah bahwa perjanjian yang menentukan nasib Israel, apapun situasi politik yang sedang terjadi, adalah perjanjian yang diberikan oleh Maharaja Israel yang sejati, yakni Yahweh. ${ }^{19}$

Akan tetapi, sebagai suatu naskah politik yang disusun dalam konstruksi teologi yang eksklusif ini mengandung semangat yang radikal. Naskah ini menonjolkan segala kekhasan Israel sebagai umat Tuhan dan secara fanatik melawan segala pengaruh [bangsa] asing, dan karenanya oleh banyak sarjana dianggap sebagai suatu naskah yang eksplosif dan berbahaya. Itu sebabnya untuk sementara waktu naskah itu harus disembunyikan agar tidak bocor ke pihak Asyur yang pada saat itu masih menjadi kekuatan yang menguasai Israel Selatan (Yehuda). 
Pada tahun 620-an, kekuasaan Asyur makin merosot sehingga Raja Yosia (640-6o9 s.M.) berhasil membebaskan diri dari Asyur. Segala unsur asing, baik politik maupun religius, disingkirkan dan segala unsur tradisional yang khas Israel dipromosikan oleh Yosia. Baginya, naskah itu merupakan suatu "hadiah" yang sangat berharga karena segala impian dan cita-cita reformasi Israel termuat di dalamnya. ${ }^{20}$

Singgih melanjutkan bahwa bukan hanya sikap intoleran yang dapat dijumpai dalam Kitab Ulangan, melainkan juga sikap eksklusif. Sebagai "bangsa yang kudus", Israel harus menjaga diri dari perkawinan campur dengan bangsa-bangsa lain dan membatasi relasi dengan macam-macam orang yang dianggap tidak layak. ${ }^{21}$ Tentang hal itu, Choang Seng Song, seorang teolog Asia dari Taiwan, menyatakan: ${ }^{22}$

"Prinsip Deuteronomis ini secara sistematis dipergunakan bukan hanya untuk mempertahankan kemurnian iman kepada Yahweh melainkan juga melanggengkan hubungan-hubungan kebencian dengan bangsa-bangsa di Kanaan."

Ulasan sejumlah pandangan dari para pemikir teologi di atas memperlihatkan betapa kokohnya paradigma "benteng pertahanan" yang dibangun dalam konsepsi "umat pilihan Allah" oleh Kitab Ulangan (Deuteronomi). Israel sebagai umat pilihan Allah bukan saja berarti umat itu dikhususkan untuk Tuhan sebagai objek perhatian-Nya dan sebagai sarana pelaksanaan kehendak-Nya sehingga mampu hidup dengan mencerminkan karakter ilahi. ${ }^{23}$ Ditegaskan pula oleh Alan Richardson:"Israel is elected not for privilege but to service, to further God's purpose for the nations." ${ }^{4}$

Perjanjian Baru (PB) juga mengangkat konsepsi ini menjadi dasar berdirinya suatu komunitas Kristen di Yerusalem yang menyebut diri mereka sebagai "Jemaat Allah" atau Ekklesia of God (bnd. 1Kor 15:9; Gal 1:13). Sebagaimana diungkap oleh Gerhard Lohfink: ${ }^{25}$ 
"Here ekklesia is understood as the true people of God, separated from all unholiness and impurity. If the earliest Christian community called it self the "ekklesia of God" against this background, it must have seen itself as the chosen people of God, the true Israel."

Eksklusivisme yang tercermin secara gamblang di dalam konsepsi inilah yang oleh sekelompok penganut aliran Kristen tertentu dijadikan landasan untuk membangun sikap yang menganggap diri sebagai orang Kristen atau Gereja sejati. Bagi mereka ini tidak ada lagi yang dapat dibandingkan dengan posisi teologis diri mereka sendiri. Kelompok-kelompok keagamaan dengan semangat semacam ini - disadari atau tidak - lebih dikenal sebagai kaum fundamentalis Kristen. Mereka menolak dengan tegas anasir-anasir asing yang mereka anggap tidak alkitabiah dalam proses pembacaan dan pemaknaan mereka sendiri terhadap teks-teks Alkitab. Bagi mereka, teks-teks Alkitab itu adalah dasar (fondasi) iman yang tidak bisa diutak-atik. Tafsiran dan sikap yang fundamentalistik terhadap Alkitab sebagai sumber dan fondasi satu-satunya iman Kristen itulah yang kemudian termanifestasi secara vulgar dalam bentuk tudingan "sesat" atau "kafir" terhadap kelompok-kelompok keagamaan liyan. ${ }^{26}$

Dalam sejarah misi Kristen, yang berjalan beriringan dengan kolonialisasi ekonomi dan politik bangsa-bangsa Barat di Asia dan Afrika, tafsir dan pandangan fundamentalistik ini menjadi teologi arus utama di wilayah-wilayah jajahan. Semangat keberagamaan yang eksklusif itu memposisikan iman Kristen sebagai yang superior karena diperkenalkan oleh patron-patron politik (penguasa/gereja) kolonial yang unggul vis-à-vis komunitaskomunitas lokal di berbagai wilayah jajahan mereka. Superioritas politik kolonial mempengaruhi pula karakter teologis Kristianitas yang diajarkan kepada para penganut Kristen lokal pada masamasa awal. Semua bentuk kebudayaan dan keberagamaan lokal dipandang inferior berhadapan dengan Kristianitas "Barat" dengan seluruh bagasi kebudayaan [Eropa] Barat. Dengan demikian, tidak terjadi komunikasi tetapi dominasi dan hegemoni, 


\section{baik pada tataran teologis maupun praksis sosial bersama dengan komunitas-komunitas liyan.}

\section{Catatan Akhir:}

1 H. Berkhof \& I. H. Enklaar, Sejarah Gereja (Jakarta: BPK Gunung Mulia, 1990), vii.

2 J. Garang, Pluralisme dalam Kebudayaan Nasional: Sorotan Agama, Masyarakat dan Negara (Jakarta: Buletin Akademi Leimena 1992), 22.

3 Harold Coward, Pluralisme: Tantangan bagi Agama-Agama (Yogyakarta: Kanisius, 1989), 31,35.

4 J. Naitbitt \& P. Aburdene, Megatrends 2000 (Yogyakarta: Binarupa Aksara 1990), 120.

5 Naisbitt \& Aburdene, Megatrends 2000, 170.

6 Naisbitt \& Aburdene, Megatrends 2000, 133.

7 Chr. de Jonge, Gereja Mencari Jawab (Jakarta: BPK Gunung Mulia, 1994), 12-13. Sejak Abad Pertengahan, Kristianitas telah mendominasi seluruh Eropa Barat. Gereja dan negara dibedakan sekaligus dihubungkan. Gereja dan negara dilihat sebagai "jiwa" dan "tubuh" masyarakat Kristen. Seluruh masyarakat merupakan tubuh Kristen, Corpus Christianum, yang dijiwai oleh agama Kristen, yang ditangani oleh gereja dan dari segi lahiriah diurus oleh negara yang menangani hal-hal jasmani, seperti politik. Namun selanjutnya timbul konflik karena masing-masing pihak berambisi untuk menguasai yang lain tanpa mau saling mengalah.

8 James Barr, Fundamentalisme (Jakarta: BPK Gunung Mulia, 1994), 43.

9 Eka Darmaputera, "Menuju Teologi Kontekstual di Indonesia" dalam Eka Darmaputera (ed.), Konteks Berteologi di Indonesia (Jakarta: BPK Gunung Mulia, 1991), 8-9.

10 Eka Darmaputera,"Pergumulan dan Peran Gereja dalam Masyarakat dan Negara Pancasila" dalam J. M. Pattisina dan W. Sairin (eds.), Gerakan Oikoumene: Tegar Mekar di Bumi Pancasila (Jakarta: BPK Gunung Mulia, 1993), 312-313.

11 D. P. Johnson, Teori Sosiologi Klasik dan Modern. Jilid 1 (Jakarta: Gramedia, 1989), 239.

12 Johnson, Teori Sosiologi Klasik dan Modern, 242.

13 Johnson, Teori Sosiologi Klasik dan Modern, 243.

14 E. G. Singgih, "Idea Umat Terpilih dalam PL: Positif atau Negatif?" dalam Th. Sumartana (ed.), Dialog: Kritik dan Identitas Agama (Yogyakarta: Seri Dian I/1 Interfidei, 1993), 38.

15 R. E. Clements, God's Chosen People (London: SCM Press, 1969), 32.

16 Singgih, "Idea Umat Terpilih dalam PL", 38.

17 Clements, God's Chosen People, 36.

18 I. J. Cairns, Tafsiran Kitab Ulangan 1-11 (Jakarta: BPK Gunung Mulia, 1994), 7.

19 Cairns, Tafsiran Kitab Ulangan 1-11, 9.

20 W. Van der Weiden, "Hidup Bermasyarakat dalam PL" dalam J. B. Banawiratma (ed.), Kemiskinan dan Pembebasan (Yogyakarta: Kanisius, 1987), 51-53. 
21 Singgih, "Idea Umat Terpilih dalam PL", 40.

22 Choan Seng Song, Allah Yang Turut Menderita (Jakarta: BPK Gunung Mulia, 1993), 67-68.

23 Cairns, Tafsiran Kitab Ulangan 1-11, 144.

24 Alan Richardson, An Introduction to the Theology of New Testament (London: SCM Press, 1969), 269.

25 Gerhard Lohfink, Jesus and Community (London: SPCK, 1985), 77.

26 Barr, Fundamentalisme, 4-5. 


\section{Bab 2 \\ Telisik Kitab Ulangan 7:1-11}

ada bagian ini akan diperiksa konteks umum penyusunan Kitab Ulangan dan interpretasi terhadap bagian Ulangan 7:1-11. Penulis sengaja tidak menggunakan berbagai perangkat metodik dan pendekatan analitis yang lazimnya harus digunakan dalam suatu ulasan eksegetis. Elaborasi bagian ini lebih menggunakan pendekatan dan analisis secara umum sebagai kerangka dari inti pemberitaan Ulangan 7:1-11 tersebut yang disusun pada konteksnya. Berdasarkan ulasan analitis itu kemudian akan ditentukan paradigma yang terkandung di dalamnya.

\section{Konteks Umum Kitab Ulangan}

Salah satu kendala terbesar dalam upaya menentukan dan mengamati situasi dan konteks penyusunan Kitab Ulangan adalah begitu variatifnya bahan-bahan yang terkandung pada dirinya. Secara luas, ini telah menimbulkan polemik yang berkepanjangan di kalangan para peneliti Perjanjian Lama (PL).

Dalam perdebatan mengenai masalah tersebut, pada tahap-tahap perkembangan penelitian selanjutnya, sejumlah ahli menerima dan mendukung teori bahwa Kitab Ulangan secara garis besar disusun dari Israel Utara. Albrecth Alt adalah salah seorang teolog PL yang kukuh memegang teori tersebut. Alt berpendapat bahwa 
bahan Ulangan disusun di lingkungan masyarakat Israel Utara dan untuk kepentingan mereka.Persoalan mengenai bagaimana bahan Ulangan bisa sampai ditemukan dalam Bait Allah Yerusalem pada masa pemerintahan Raja Yosia (Israel Selatan), masih menjadi misteri yang belum terpecahkan. Seperti Alt, John Bright setuju bahwa tradisi-tradisi yang menjiwai bahan Ulangan berasal dari Israel Utara dan menduga bahwa bahan-bahan ini kemudian dibawa ke Selatan (Yehuda) lalu diformulasikan ulang menjadi rumusan yang mendorong terjadinya reformasi. Salah seorang teolog PL lainnya, Ernest W. Nicholson, mengemukakan beberapa faktor penting yang mengarah kepada kesimpulan bahwa bahan Ulangan berasal dari lingkungan Israel Utara dan mempunyai keterkaitan yang erat dengan tradisi kenabian di sana. ${ }^{27}$

"they both stand upon the tradition of the old Israelite amphictyony - they concern for the observance of covenant law, their strong attachment to the principles of charismatic leadership and their critical attitude towards the monachy. The attitude of Deuteronomy towards the institution of kingship indeed has been taken by many as on of the strongest links between it and the traditions of northern Israel."

Sementara Adam C. Welch, dalam kerangka persoalan di atas, melihat adanya hubungan antara bahan Ulangan dan Hosea. Dia yakin bahwa Ulangan 15:14 dyb merupakan gambaran sikap terhadap konteks di Utara dan ada keterkaitan dengan sikap Hosea. $^{28}$ Welch juga mengamati adanya kesejajaran antara bahan Ulangan dengan Sumber E dalam Pentateukh. ${ }^{29}$ Dengan mencermati pandangan sejumlah teolog tersebut maka dapat disimpulkan asumsi keberakaran tradisi Ulangan di Israel Utara dapat diterima.

Paruhan pertama abad ke-8 s.M. merupakan masa kembalinya kemakmuran di Israel (Utara), khususnya di bawah pemerintahan Yerobeam II, raja ke-4 dari Dinasti Yehu. Kedua kerajaan Ibrani itu bebas dari gangguan negara luar; Damsyik terlalu lemah setelah dihajar oleh Asyur sehingga tidak mungkin memperbarui agresinya. Yerobeam kemudian makin memperluas batas-batas 
kerajaannya dan kemakmuran nasional bertambah besar-besaran. Ini membawa suatu kondisi kehidupan yang mapan dan makmur di kalangan masyarakat Israel Utara pada saat itu.

Tetapi rupanya peningkatan kemakmuran besar-besaran dalam skala nasional ini, pada sebelah lain, membawa dampak negatif yang cukup fatal terhadap sistem kehidupan sosial masyarakat. Munculnya dan diberlakukannya sistem-sistem sosial yang tidak adil di mana kemakmuran nasional tersebut dinikmati dan dikuasai hanya oleh segelintir orang saja, yaitu para pedagang kaya dan tuan-tuan tanah yang memperkaya diri atas jerih payah para petani; para lintah darah yang memangsa kaum petani kecil dengan pinjaman disertai bunga yang tinggi; para hakim yang menyelidiki perkara-perkara hukum dengan sogokan dan menjatuhkan keputusan dengan tidak adil. ${ }^{30}$ Bahkan ada juga orang-orang yang bertingkah layaknya seorang nabi yang menubuatkan hal-hal yang dikehendaki oleh para pendengarnya, bukan menubuatkan kebenaran (bnd. Ul. 18:20-22). ${ }^{31}$

Perbedaan yang sangat tajam antara dua kelompok di dalam struktur masyarakat Israel yang merdeka inilah yang mendorong timbulnya kecaman-kecaman yang keras dari para nabi, seperti Amos dan Hosea. Kecaman itu bukan saja karena ketidakadilan yang dilakukan oleh golongan kaya tetapi juga karena kemunafikan mereka. Mereka tetap beribadah dan mempersembahkan korban kepada Yahweh; seolah-olah apa yang mereka lakukan kepada kaum miskin dan tertindas bukanlah faktor yang mempengaruhi peribadahan mereka. Nabi-nabi terus menyatakan bahwa yang dituntut oleh Yahweh dari umat-Nya bukanlah persembahan ternak yang tambun melainkan kebenaran dan kesetiaan kepada perjanjian, yang apabila tidak diaplikasikan maka bangsa itu akan ditimpa malapetaka yang lebih besar dari sebelumnya.

Kira-kira tahun 745 s.M. Dinasti Yehu berakhir sebagaimana mulainya, yaitu dengan pembunuhan dan pemberontakan. Pada tahun itu, Tiglat Pileser III menjadi Raja Asyur dan memulai 
agresi militernya terhadap bangsa-bangsa lain. Pada kurun waktu kurang dari seperempat abad, ia mengakhiri eksistensi Kerajaan Israel dan merenggut kemerdekaan Kerajaan Yehuda. Menahem dari Israel (745-737 s.M.) membayar upeti kepada Tiglat Pileser III tetapi suatu politik anti Asyur telah direncanakan oleh Pekah (736-732 s.M.), yang berkoalisi dengan Damsyik untuk menghadapi Asyur (peristiwa di mana Yotam dan anaknya, Ahaz, hendak dilibatkan namun ditolaknya sehingga pecah perang yang dikenal dengan Perang Syiro-Efraim). ${ }^{32}$ Tiglat Pileser merebut Damsyik, menghapuskan kerajaan tersebut dan menjadikannya provinsi Asyur. Kalangan lapisan atas dari penduduk kedua daerah ini diasingkan dan digantikan dengan para imigran dari wilayahwilayah lain Kerajaan Asyur.

Sewaktu Hosea, raja terakhir Israel, tidak membayar upeti kepada Asyur malah mengadakan perjanjian dengan Mesir guna menghadapi Asyur, ia dipenjarakan. Asyur di bawah pemerintahan Raja Shalmaneser bergerak dan pada tahun 724 s.M. melakukan pengepungan terhadap kota Samaria selama dua tahun. Pada waktu itu, Shalmaneser wafat dan digantikan oleh Sargon II (722705 s.M.). Di bawah pemerintahan Sargon II inilah Israel Utara jatuh dan dijadikan pusat pemerintahan provinsi Asyur wilayah Samaria. Dengan melanjutkan kebijakan Tiglat Pileser dulu maka Sargon II memindahkan orang-orang taklukannya ke wilayahwilayah lain. Kebijakan tersebut diterapkan guna mengantisipasi kemungkinan munculnya pemberontakan yang terorganisasi oleh bangsa taklukan. ${ }^{33}$

Dengan runtuhnya Kerajaan Israel Utara maka dapat diduga bahwa ada kelompok orang Lewi dan pemelihara tradisi turut mengungsi ke Selatan saat itu, dengan kemungkinan mereka membawa serta bahan tradisi Ulangan itu. Tidak dapat dipastikan apakah naskah Ulangan 5-26 (atau 5-30) pada dasarnya sudah lengkap saat itu namun setidak-tidaknya dapat diduga bahwa proses penyusun bahan sudah cukup maju. 
Setelah dibawa ke Yerusalem, mereka melakukan penyelarasan agar bahan Ulangan itu dapat "diakarkan" di Yehuda. Sebagai golongan imam dan Lewi, mereka memiliki kemampuan untuk menyelaraskan dan menginterpretasi bahan Ulangan tersebut. Seperti tanggapan Von Rad: ${ }^{34}$

"The custodians of such a priestly and the cultic tradition can only have been Levites. Only priests, it is maintained, could have access to such a wide range of cultic material and, more important still, only priests could have had the authority to expound and re-interpret these old tradition and laws in the free manner in which the authors of Deuteronomy have treated them.

Sekelompok imam dan kaum Lewi tersebut mencoba untuk mengumpulkan bahan-bahan (Ulangan) dari masa lampau dan (sesuai dengan tuntutan zaman) menyadur serta melengkapi bahan tersebut sedemikian rupa sehingga juga berfungsi sebagai cita-cita kawan-kawan sebangsa. ${ }^{36}$

Kemungkinan besar bahan Ulangan berpengaruh dalam pembaruan agama yang dijalankan oleh Hizkia, Raja Yehuda, sekitar tahun 705 s.M. (bnd. 2Raja 18). Tetapi pada tahun 697 s.M. Raja Hizkia wafat dan digantikan oleh anaknya, Manasse. Selama masa pemerintahan Manasse (696-642 sM), ${ }^{37}$ dan anaknya, Amon (641-640 sM), mazhab Ulangan agaknya bekerja sembunyisembunyi. Karena pada saat itu Yehuda sementara berada di bawah kekuasaan Asyur dengan pemerintahan Raja Ashur-banApal. Masa ini merupakan yang terburuk bagi eksistensi dan praktik-praktik keagamaan Israel.

Selama masa pemerintahan Manasse, mazhab Ulangan bekerja menyusun bahan Ulangan dengan suatu pengharapan besar bahwa suatu saat kelak kekuasaan yang menindas dan melecehkan agama Yahweh itu akan hancur dan sekali lagi (sebagaimana dalam masa pemerintahan Hizkia) memperoleh kesempatan untuk reformasi. ${ }^{38}$ Mazhab Ulangan mendapatkan kesempatannya dengan diangkatnya Yosia menjadi raja pada tahun 639 s.M. Bahkan ada kemungkinan besar bahwa beberapa tokoh dari 
mazhab ini termasuk golongan "pemuka" (bnd. Zef 1:28) yang membimbing raja muda itu sebelum dia cakap bertindak sendiri.

Setelah mengambil tanggung jawab penuh atas pemerintahannya, Yosia mulai mengadakan upaya pemurnian ibadah di Yerusalem dengan jalan menghentikan berbagai jenis peribadahan asing, serta menegakkan kembali kultus Yahwisme. Gerakan reformasi itu kemungkinan dimulai sekitartahun 627 s.M. (bnd. 2Taw 34:3), karena dalam proses pembersihan dan pembenahan Bait Allah pada tahun 621 s.M. ditemukan sebuah naskah Tora (Kitab Hukum). Persoalan apakah naskah itu baru ditemukan setelah sekian lama terlupakan, atau memang dengan sengaja dikeluarkan oleh mazhab Ulangan ketika melihat kesempatan yang baik, tidaklah menjadi persoalan yang berpengaruh. Yang penting ialah penemuan naskah tersebut makin memberi dorongan yang kuat terhadap gerakan reformasi yang rupanya sementara berlangsung. ${ }^{39}$

Kisah tentang penemuan naskah tersebut dapat dilihat dalam 2Raja 22:11-13. Disebutkan di situ bahwa Raja Yosia beserta pembesar-pembesarnya cukup terkejut mendengar dan membaca isi naskah tersebut. Bagi Raja Yosia, naskah tersebut merupakan hadiah terbesar karena segala impian dan obsesinya termuat di dalamnya. Oleh karena naskah tersebut dulu secara fiktif disusun seolah-olah suatu laporan harfiah dari pidato terakhir Musa kepada umat Israel sebelum mereka menyeberangi Sungai Yordan untuk memasuki "Tanah Perjanjian" (Kanaan). Dengan demikian, makin menguat perspektif teologis bahwa Yosia dengan segala usahanya menerima pengesahan paling tinggi berkat isi naskah, yakni pengesahan oleh Musa sendiri, perantara Allah dengan Israel ketika menerima Perjanjian di Sinai (Horeb).

\section{Konteks Khusus Ulangan 7:1-11}

Setelah melihat konteks umum Kitab Ulangan, maka pada bagian ini akan dicermati konteks khusus Ulangan 7:1-11. Kitab Ulangan dapat dibagi secara garis besar sebagai berikut: ${ }^{40}$ 
1. Pidato Musa I: Pendahuluan untuk bagian anjuran (pasal 6-11). Pasal 1-3: Pidato yang menceritakan perjalanan Israel dari Sinai sampai tanah Moab. Pasal 4:1-40: Addendum (tambahan) kepada pidato: anjuran supaya Israel hidup setia kepada kehendak Tuhan yang dinyatakan di Sinai (Horeb). Pasal 4: 4144: Beberapa catatan

2. Teofani Sinai: Pendahuluan Pidato Musa II. Pasal 5: Dekalog diberi dalam rangka teofani menjadi inti penyataan kehendak Tuhan bagi umat pilihan-Nya.

3. Pidato Musa II: Pasal 6-11: Bahan anjuran (terdiri dari fragmen-fragmen khotbah): "Haruslah umat itu mengasihi Tuhan dengan segenap hati mereka, mengingat bahwa Tuhan telah demikian menaruh kasih-Nya atas mereka".

4. Kodeks Ulangan: Lanjutan Pidato Musa II (12-26:15)

5. Pengesahan Perjanjian:

a. Formulir Pengesahan Perjanjian. Penutup pidato Musa II (26:16-19)

b. Liturgi-liturgi pengesahan Perjanjian: addendum kepada pidato Musa II

i. Pasal 27: Liturgi pengesahan dikuatkan dengan sanksisanksi berupa berkat-berkat atas ketaatan dan kutuk yang menimpa karena pelanggaran

ii. Pasal 28: Rentetan berkat dan kutuk, yang pernah merupakan bagian liturgi lain, untuk pengesahan perjanjian

6. Pidato Musa III: Liturgi pengesahan perjanjian di Tanah Moab. Pasal 29:1-18: Anjuran.Pasal 29:19-28: Rentetan Kutuk. Pasal 29:29-30:20: Anjuran. Penutup pidato Musa III

7. Addenda

a. Pengganti Musa:

i. Pasal 31:1-8, 14-15, 23: Yosua ditunjuk dan ditetapkan sebagai pengganti Musa

ii. Pasal 31:9-13, 24-29: Naskah Torah diserahkan kepada kaum Lewi untuk ditempatkan di samping Tabut 
Perjanjian dan akan dibacakan secara periodik pada hari-hari raya Pondok Daun

b. Nyanyian Musa:

i. Pasal 31:16-22: Pendahuluan Nyanyian Musa

ii. Pasal 32:1-43: Nyanyian Musa

iii. Pasal 32:44-47: Penutup Nyanyian Musa

c. Berkat Musa: pasal 33:1-29

d. Kematian Musa:

i. Pasal 32:48-52: Pra-pemberitahuan tentang kematian Musa

ii. Pasal 34:1-12: Kematian Musa

Jika mencermati struktur Kitab Ulangan yang cukup rumit maka dapat disimpulkan bahwa rupanya kitab ini telah mengalami serangkaian proses perkembangan tahap demi tahap berturutturut. Rangkaian-rangkaian tersebut sudah melebur menjadi struktur gabungan yang kompleks.

Salah satu masalah yang cukup kontroversial di dalam perdebatan mengenai kesatuan Kitab Ulangan ialah masalah dua pendahuluan, yakni pasal 1-4 dan 5-11. Namun, hasil penelitian yang cemerlang telah dilakukan oleh Martin Noth. Menurut Noth, anjuran I, pasal 1-3 dalam Kitab Ulangan bukanlah pendahuluan dari kitab ini melainkan lebih merujuk kepada Sejarah Deuteronomistis Israel mulai dari Musa sampai ke pembangunan Bait Allah (dari Ulangan - 2Raja). Sedangkan pasal 5-11 disetujui, baik secara keseluruhan maupun sebagian, bentuknya memang asli (orisinal) pendahuluan dari kitab ini. ${ }^{41}$

Baik dalam bagian Kodeks Ulangan (12-26), hukum yang utama, yaitu "Kasihilah Tuhanmu dengan segenap hatimu", mendapat aksentuasi yang sangat kuat. Bahkan hukum kasih ini tidak diperintahkan begitu saja tetapi dijadikan pokok anjuran, renungan, dan khotbah. Menarik bila kita mulai menelusuri masalah ini dengan pertanyaan: Siapakah para pengkhotbah 
atau pengajar ini, yang berusaha mempengaruhi dan menasihati umatnya dengan nada yang begitu urgen?

Dalam upaya menjawab persoalan ini, Gerhard von Rad menghubungkannya dengan Kitab Nehemia 8:1-9: "Ezra membuka kitab itu di depan mata seluruh umat... juga Yesua, Bani, (dan lain-lain)... yang adalah orang Lewi, mengajarkan Taurat itu kepada orang-orang itu... bagian-bagian dari pada kitab itu, yakni Taurat Allah, dibacakan dengan jelas dengan diberi keteranganketerangan sehingga pembacaan dimengerti". ${ }^{42}$ Rupanya Ezra membacakan naskah Torah itu dalam bahasa Ibrani, sedangkan orang-orang Lewi menjelaskannya dalam bahasa Aram (bahasa rakyat saat itu) dengan memberikan interpretasi dan ulasan panjang. Von Rad mengakui bahwa jarak waktu antara zaman Ezra (awal abad ke-4 atau akhir abad ke-5 s.M.) dengan masa penyusunan bahan Ulangan itu (akhir abad ke-8 sampai awal abad ke-6 s.M.) cukup jauh. Namun demikian, ia tertarik kepada fenomena bahwa tugas "berkhotbah" yang pada kenyataannya dipegang oleh kaum Lewi dalam Nehemia 8 sudah lama termasuk kebiasaan golongan mereka, bahkan sejak masa bahan Ulangan sementara berkembang. Jadi, Von Rad menarik kesimpulan bahwa suara kaum Lewi itulah yang terdengar dalam anjuran-anjuran Kitab Ulangan.

Memang secara umum para ahli berpendapat bahwa baik Kodeks Ulangan (12-26) maupun bahan anjuran (5-11) diolah dalam upacara-upacara ibadat selama hari-hari raya yang berlangsung secara periodik di Israel Utara. Dalam pasal 31:10-13 termaktub ketentuan bahwa setiap tujuh tahun sekali bagian-bagian dari Torah ini harus dibacakan kepada umat yang sudah berkumpul di "tempat yang Tuhan pilih" itu. Dugaan yang mungkin ialah bahwa dalam pengertian semula maka "tempat yang Tuhan pilih" itu adalah Sikhem $(27: 4,12-13)$ yang pada fase pertama dalam sejarah Israel di Kanaan menjadi tempat ibadah utama di Israel Utara. Selanjutnya "tempat yang Tuhan pilih" itu diartikan sebagai Yerusalem. 
Di dalam kebiasaan seperti itulah Torah makin mencapai bentuknya yang lebih lengkap dan makin menyerupai Kodeks Ulangan yang dikenal sekarang. Sudah pasti bahwa pembacaan itu juga disertai khotbah-khotbah serta anjuran-anjuran supaya Israel sungguh-sungguh menghayati persekutuan dan perjanjian yang telah Tuhan buat. Fragmen-fragmen dari khotbah-khotbah yang disampaikan turun-temurun itu disusun dengan penuh perhatian dan perawatan oleh kaum Lewi dan akhirnya digarap serta disusun menjadi bahan Ulangan 5-11.

\section{Teologi Kitab Ulangan}

Setelah melihat konteks Kitab Ulangan, baik secara umum maupun khusus, dalam Ulangan 7:1-11 maka nuansa teologi Ulangan akan dapat dipahami dengan lebih jelas. Dari dalamnya akan dapat dimengerti bagaimana kandungan nilai-nilai teologis yang menjiwai Ulangan (Deuteronomi), serta menjadi landasan bagi sikap etisnya di tengah konteks.

Secara garis besar teologi Deuteronomi dapat diringkas dalam tigas rumusan: "satu Allah, satu umat, satu kultus". Dapat juga ditambahkan: "satu tanah, satu raja, satu nabi". ${ }^{43}$

\section{Umat Israel memang mengakui adanya pluralitas tempat peribadahan (Kel. 20:24)}

Bahkan beberapa di antaranya dijadikan atau dianggap sebagai pusat peziarahan. Akan tetapi, di tengah situasi sedemikian Deuteronomi menuntut kekhususan satu tempat ibadah (12:13 dyb). Atau, dapat dikatakan bahwa rumusan Deuteronomis yang khas memberikan pembenaran teologis bagi sentralisasi kultus, "tempat yang akan dipilih TUHAN" mengacu pada berbagai tempat yang telah Tuhan tetapkan berturut-turut. Kedua indikasi tempat, "di daerah salah satu sukumu" dan perbedaan cara-cara mempersembahkan korban bakaran maupun korban sembelihan menunjukkan suatu versi tua (kuno) dari hukum sentralisasi kultus (12:13-19), yakni mengenai hubungan iman Yahwistik dengan satu-satunya tempat ibadah secara eksklusif. Di dalam 
pengertian inilah reformasi Yosia harus dipahami. Identifikasi "tempat yang akan dipilih TUHAN" dengan Yerusalem secara jelas menunjukkan tahap yang lebih tua, namun tidak tampak secara langsung di dalam perkembangan kemudian.

Rumusan sentralisasi kultus, "tempat yang akan dipilih TUHAN" $(12: 14,18,26)$, ini juga disertai dengan motivasi, yaitu "untuk menegakkan nama-Nya di sana" (12:21) atau "untuk membuat nama-Nya diam di sana" (12:11). Dalam pengertian yang luas, Allah memilih salah satu tempat ibadah di mana di dalamnya Ia hadir. Namun dalam penelitian terhadap persoalan ini ada pendapat yang menyatakan bahwa Allah sendiri menetap di surga (Ul. 26:12;4:36) dan "hanya" nama-Nya yang diam di bumi. Perbedaan antara Allah dan kehadiran Allah di bumi ini berarti sesuai dengan pandangan yang lebih tua di mana Allah sendiri yang "diam" dalam tempat ibadah (bnd. 1 Raja 8:12; Yes.7:18).

Seruan atau perintah untuk memusatkan ibadah pada satu tempat membawa perubahan-perubahan yang radikal dalam kultus dan kehidupan keagamaan Israel, khususnya bagi mereka yang tinggal di wilayah pedesaan di luar Yerusalem. Akibatnya (yang prinsipil) adalah kelunakan dalam persyaratan untuk menggunakan hewanhewan sembelihan yang "profan" (dilarang) (12:15). Jadi, sebagai perbandingan dengan korban bakaran yang sepenuhnya diadakan di tempat kudus maka korban sembelihan yang dilakukan di tempat-tempat yang jauh dari pusat peribadahan (ayat 20 dan seterusnya) dapat atau boleh dimakan. Hanya "darah"-nya yang tidak boleh turut dimakan (12:16,23 dyb). Itu berarti peraturan baru dalam Deuteronomi merupakan gagasan kuno yang mendukung aksi sekularisasi besar-besaran di Israel.

Tuntutan sentralisasi kultus ini juga mempengaruhi peraturanperaturan persepuluhan, anak sulung dan buah sulung (12:22-27; 15:9-23; 26:1 dyb), penanggalan hari raya (16:1 dyb), juga yang berkaitan dengan para hakim dan imam (17:8-13; 18:1-8). Jadi dapat disimpulkan bahwa peraturan-peraturan yang berkaitan 
dengan sentralisasi ibadah ini menggambarkan tingkatan dalam materi hukum di kemudian hari. Namun demikian, Deuteronomi juga memberikan suatu interpretasi yang menghubungkan berbagai tradisi di bawah satu maksud.

\section{Kesatuan kultus dalam Deuteronomi merupakan konsepsi dari keesaan Allah}

Ini tercermin dalam pernyataan yang khas dalam shema: "Dengarlah, hai orang Israel: Tuhan itu Allah kita, Tuhan itu esa" (6:4). Pernyataan iman yang dibicarakan dalam Deuteronomi ini tidak menggambarkan sesuatu yang insidental atau situasi yang sementara, tetapi sesuatu yang universal dan sangat prinsipal. Dengan dasar pikiran seperti inilah maka Deuteronomi dapat bergerak ke berbagai arah serta memiliki beberapa tingkat pengertian. Dalam pengertian sebenarnya, Deuteronomi sukar untuk diinterpretasi sebagai seruan bagi gerakan monoteisme (Yahweh adalah satu-satunya Allah; lih. 4:19, 35; 32:39) karena pada satu sisi, Deuteronomi dalam hubungannya dengan bangsa-bangsa sekitar menolak segala kegiatan agama Kanaan, serta mengandung seruan untuk mengakui keesaan Yahweh yang mengatasi segala bentuk yang dipakai dalam kultus Baal. Sementara pada sisi lain, dalam kaitannya dengan kehidupan Israel sendiri, Deuteronomi harus dimengerti dalam konteks seruan untuk sentralisasi kultus sebagai suatu pengakuan akan keesaan Yahweh yang diperhadapkan dengan keberagaman tradisi-tradisi yang berbeda, serta tempat-tempat peribadahan Yahweh. Kedua interpretasi ini dapat dipertemukan sepanjang akibat-akibatnya tetap diperhatikan karena penekanan atas keesaan dalam bentuk agama Yahwistik dapat mendorong penempatannya terlepas dari manifestasi-manifestasi agama Baal.

Dengan demikian, Deuteronomi menempati posisi yang sangat penting dalam sejarah iman Yahwistik karena memberikan pernyataan yang baru pada perintah pertama. Dalam bentuk yang tua (Kel. 22:20; 34:14 dyb) perintah ini menetapkan relasi antara Allah dengan manusia tanpa membuat pernyataan langsung 
tentang diri Allah. Namun, dalam Ulangan 6:4 pengakuan tersebut mengalami pergeseran makna. Ini terjadi karena Deuteronomi mengambil bentuk keesaan Allah dari klaim bahwa Yahweh harus disembah secara khusus (eksklusif) dan menggantikannya dengan pernyataan "tentang diri Allah" (Kel 34:6 dyb). Namun dalam kekhasan PL maka beberapa pernyataan yang mengartikan nature (sifat dasar Allah) tidak ditinggalkan begitu saja. Sebaliknya, bersamaan dengan itu disertakan juga respons dari manusia: "Kasihilah Tuhan, Allahmu dengan segenap hatimu, dan dengan segenap jiwamu dan dengan segenap kekuatanmu" (6:5; bnd. 5:10; 7:9; 10:12; 11:1, 13, 22; 13:3 dyb; 19:9).

Dalam bagian lain, perintah pertama sekali lagi diberi suatu interpretasi yang baru. Rumusan-rumusan tua yang bernada negatif biasanya melarang umat untuk beribadah kepada allahallah asing tetapi tidak mengatakan sesuatu yang positif dan gamblang tentang "bagian terdalam" dari hubungan Israel dengan Yahweh. Deuteronomi, pada sisi yang lain, menerima eksklusivitas antropologis sebagai totalitas tingkah laku. Keesaan Allah harus dihadapi sepenuhnya, yang dengan terbuka menarik semua orang untuk berbalik kepada Allah.

Dalam nasehat-nasehat (anjuran), hubungan yang tidak terbatas dengan Allah digambarkan melalui istilah-istilah seperti "taat pada", "melayani", "mengikuti" Allah atau "tidak melupakan", "disadarkan akan dia" (6:12 dyb; 8:18 dyb; 10:20). Dari sini timbul pernyatan: Apakah konsep-konsep ini, dan dalam kenyataan seluruh perkembangan dari perintah pertama, mencerminkan atau memperlihatkan adanya pengaruh kenabian (lih. Hos $2: 13 ; 3: 1)$ ? Sebagaimana dapat diamati bahwa pengaruh kenabian kemungkinan tidak ditemukan dalam kitab-kitab PL lainnya seperti halnya dalam Deuteronomi dan tulisantulisan Deuteronomi selanjutnya. Di dalamnya tidak hanya ada peraturan-peraturan individu yang berkaitan dengan nabi-nabi tertentu yang muncul dari antara umat, yang menyerukan kepada seluruh umat untuk beribadah kepada allah-allah lain (13:1-18) 
atau mereka sendiri yang menyembah allah-allah asing tersebut (17:2-7; bnd. 12:30; 18:20). Ditambahkan juga bahwa pada mulanya pertimbangan-pertimbangan umum dari kepentingan hukum (7:4 dyb; 8:9; 11:16 dyb) adalah memberikan ketegasan akan arti penting dari perintah pertama. Keturunan Israel akan menjadi penyembah berhala dan "melupakan" sejarah masa lampau. Jadi di sini ada dua jenis pelanggaran yang dipakai oleh Deuteronomi. Pelanggaran-pelanggaran ini sebenarnya mencabut iman Yahwistik dari esensinya.

Oleh karena itu, sepuluh hukum (dekalog), yang menggabungkan acuan historis dan tuntutan untuk eksklusif/kekhususan (5:6 dyb), sudah seharusnya menempati posisi yang istimewa dibandingkan dengan peraturan-peraturan lainnya. Sebagaimana dalam kisah di Sinai (Horeb) (Kel. 20), demikian juga dalam Deuteronomi pada tahap perkembangan pemikiran yang kemudian - dekalog hadir sebelum ada segala "undang-undang dan aturan-aturan" dan diperkenalkan bukan sebagai perkataan yang diucapkan oleh Musa melainkan secara langsung sebagai Firman Allah (5:4, 22 dyb; bnd. 5:5). Akibatnya, seluruh hukum maupun peraturanperaturan selanjutnya hanya menjadi instruksi-instruksi untuk menerapkan dekalog. Sama seperti "perjanjian" diinterpretasi dalam hubungan dengan dekalog (4:12 dyb; 5:2; 9:9 dyb) sedangkan Tabut menjadi tempat untuk menyimpan dua loh batu yang berisi sepuluh perintah (10:1 dyb; bnd. 31:26).

Sementara hukum-hukum yang lebih tua ditujukan kepada individu-individu, Deuteronomi ditunjukan kepada umat Allah sebagai suatu keseluruhan ${ }^{44}$

Dalam beberapa kasus, kesatuan umat dapat disamakan dengan keesaan Allah: Yahweh berhadapan dengan "seluruh Israel" (5:1 dst). Dalam Deuteronomi juga tidak ada pembagian umat menjadi suku-suku atau menjadi Kerajaan Utara dan Kerajaan Selatan. 45

Pada satu sisi, Deuteronomi menanamkan kesan kepada para pendengar dan pembacanya bahwa Yahweh adalah "Allahmu" 
(baik dalam bentuk tunggal maupun jamak). Sedangkan pada sisi yang lain, Israel disebut sebagai "kepunyaan Allah" suatu "umat yang kudus" (7:6; 14:2; 26:18 dan seterusnya).

Dua sisi dari hubungan antara Allah dan umat-Nya diringkas dalam Ulangan 26:17 dyb dengan suatu "rumusan perjanjian" tetapi pada hakekatnya dapat disebut suatu "prinsip permulaan dan kekal" (Julius Wellhausen) dari sejarah Israel: "Yahweh, Allah Israel; Israel, umat (milik) Yahweh".

Deuteronomi sengaja mencoba untuk menghindari bahaya salah pengertian tentang posisi istimewa yang dimiliki Israel ini dengan menyatakan bahwa kekudusan Israel semata-mata adalah hubungan yang ditetapkan oleh Allah sendiri: "Bukan karena lebih banyak jumlahmu dari bangsa manapun juga, maka hati TUHAN terpikat olehmu dan memilih kamu - bukankah kamu ini yang paling kecil dari segala bangsa?” (7:6). Relasi antara Allah dengan umat-Nya ini merupakan inisiatif Allah sendiri, yaitu dengan "pemilihan" (bahar) yang didasarkan atas kasih Allah (4:37 dyb $)^{46}$ dan dijanjikan tanpa persyaratan apapun bersamaan dengan sumpah kepada leluhur Israel (ini juga merupakan bagian atau unsur yang khas dalam tulisan Deuteronomik dan Deuteronomistik). Israel, oleh karena itu, memiliki tanah bukan karena kemampuan dirinya atau karena ia pantas mendapatkannya melainkan hanya karena janji Allah (9:5; bnd. 8:17). Kekudusan dari tempat berlangsungnya kultus (12:14 dyb) atau kaum Lewi (21:5 dyb) juga bergantung pada "pemilihan" Allah. Pengertian ini terkandung di dalam apa yang disebut dengan "teologi pemilihan".

\section{Deuteronomi menggunakan kesatuan umat Allah sebagai dasar} bagi pernyataannya mengenai kehidupan sosial umat manusia Pemegang jabatan (kuasa) tertinggal berasal dari "antara saudara-saudaramu”, yakni nabi $(18: 15,18)$ dan raja (17:15), yang hak-haknya dengan tegas dibatasi agar supaya "jangan tinggi hati terhadap saudara-saudaranya" (17:20). Di sini tampak suatu 
pandangan bahwa walaupun terdapat berbagai peranan namun semuanya sama di hadapan Allah.

Kepada sesama "saudaramu yang miskin" (15:2 dyb, 7 dyb; juga Im. 25:35 dyb) umat Israel tidak boleh mengeraskan hati melainkan siapa yang memberikan utang, dinasehati untuk menghapuskannya agar orang miskin juga memperoleh bagian dalam anugerah Allah. Selain itu, bukan hanya pada "para janda dan yatim piatu" (Kel. 22:22-24; Yes. 1:17,23) perhatian harus diberikan tetapi juga kepada "orang asing" atau "warga kota yang membutuhkan perlindungan" (gerim), yang hidup jauh dari keluarga dan saudara, yang tidak memiliki tanah sendiri dan karenanya tidak mempunyai hak-hak yang pasti, seperti kaum Lewi. ${ }^{47}$

Suasana persaudaraan yang sama juga tampak dalam berbagai hukum yang diringkas sebagai "hukum pengasih sesama" (15:1$18 ; 2: 1-8 ; 23: 15-25 ; 24: 6,10-22 ; 25: 1-4)$. Di antaranya yang mengatur "hak" untuk bebas dari ikatan tugas militer yang bertujuan memberikan kesempatan kepada individu untuk menikmati miliknya yang baru, apakah itu berupa rumah, kebun anggur atau istri (20:5-7) agar dengannya ia bersukacita dalam pemberian Allah yang baik atasnya $(12: 7,12,18 ; 16: 11,14 ; 24: 5)$.

Menurut hukum perang (20:10 dyb, 19 dyb), sikap kasih persaudaraan juga harus ditunjukkan dalam perlakuan terhadap orang asing (10:18; 24:18; bnd. 23:20 dyb), serta bermurah hati kepada musuh-musuh. Hanya kepada orang Kanaan dilarang untuk menjalin hubungan persaudaraan karena kehadiran agama mereka sangat berbahaya bagi iman Israel (7:4 dyb, 25; 12:2 dyb, 30 dyb). 


\section{Kesatuan umat Allah tidak hanya terungkap dalam kehidupan}

Israel secara umum pada suatu waktu tertentu, tetapi juga dalam visi yang berkesinambungan dari generasi ke generasi sampai kepada yang hidup di "hari ini"

Ini merupakan penghadiran kembali masa lampau atau sejarah: "Tuhan telah membawa kamu" (4:20) - atau "kita" (6:20 dyb; 26:6 dyb) - keluar dari Mesir". Perkataan Musa ini, melampaui waktu berabad-abad berkenaan dengan kehidupan sekarang (5:1). Sebagaimana halnya para nabi dalam masa pembuangan yang dapat mempertentangkan yang "lama" dan yang "baru", apa yang telah terjadi dan apa yang sementara terjadi (Yes. 43:18 dyb). Jadi, Deuteronomi menempatkan masa lampau dan masa kini bersama-sama sebagai bagian yang tak terpisahkan (5:3). Deuteronomi memang tidak mempunyai pengharapan eskatologis dalam arti yang sebenarnya. Akan tetapi, Deuteronomi melihat jauh melampaui kekinian dan yang menjanjikan bahwa ketaatan akan membawa "umur panjang" (5:16; 6:2; 11:9, 21), "bebas" dari ancaman musuh (12:9, 15; 24:19), kesuburan alam serta berakhirnya segala kesakitan dan penderitaan (7:13 dyb). Persoalan apakah berkat itusudah diberi atau baru diberi sekarang merupakan persoalan yang sulit untuk dicari jawabannya. Jadi, pemenuhan sejati dari kehidupan manusia mungkin tetap tidak dapat diwujudnyatakan.

\section{Tafsiran Ulangan 7:1-11}

Bagian ini merupakan ulasan interpretatif terhadap Ulangan 7:1-11. Langkah eksegese yang dilakukan di sini diupayakan memunculkan berbagai nilai dan nuansa guna mencari semacam paradigma sebagai umat pilihan Allah.

Ayat (1)

"Apabila Tuhan, Allahmu, telah membawa engkau ke dalam negeri, ke mana engkau masuk untuk mendudukinya, dan menghalau banyak bangsa dari depanmu, yakni orag Het, orang Girgasi, orang Amori, orang 
Kanaan, orang Feris, orang Hewi dan orang Yebus, tujuh bangsa, yang lebih banyak dan lebih kuat dari padamu,"

Dalam ayat (1) di atas dapat dilihat dengan jelas terperinci tujuh bangsa (שבעה גוֹים) yang disebut sebagai penduduk asli Kanaan. Daftar ini memang tidak baku. Artinya, jumlah penduduk asli Kanaan tidak selalu tujuh suku bangsa. Ada yang mencatat sepuluh bangsa (Kej. 15:19-21), lima bangsa (Kej. 10:15-18), enam bangsa (Kel. 3:8, 17; Ul. 20:17), tujuh bangsa (Yos. 3:10). Kemungkinan pengarang menonjolkan angka "tujuh" di sini sebagai suatu jumlah yang bulat, dalam arti segenap kekuatan bangsa-bangsa pagan. Untuk lebih jelas akan dilihat secara terperinci di sini:

1. החתי (orang Het). Bangsa Het asli merupakan bangsa nonsemit yang menduduki wilayah Anatolia (Turki Tengah) sejak milenium III s.M. Selama milenium II, kerajaan mereka bertambah kuat sehingga pada masa jayanya kerajaan itu meliputi wilayah Mesopotamia dan Siria. Kerajaan Het asli itu diruntuhkan oleh Asyur sekitar tahun 1200 s.M. Pada abadabad kemudian istilah "Het/hetit" dipakai secara umum untuk menunjukkan suku bangsa yang dahulu takluk kepada kerajaan Het-asli itu termasuk beberapa kelompok penduduk asli SiriaKanaan. Dalam PL, orang Het merupakan bangsa besar yang membakukannya namanya bagi seluruh daerah Siria, "dari padang gurun dan gunung Libanon... sampai ke Sungai Efrat, seluruh tanah orang Het, sampai ke laut besar disebelah matahari terbenam..." (Yos. 1:4); kedua, golongan etnis yang hidup di Kanaan sejak zaman para leluhur hingga orang Israel menetap (Kej. 15:20; Ul. 7:1; Hak. 3:5) yang secara harfiah disebut "anak-anak Het" (Kej. 23:3 dst). Menurut moyangnya, Het adalah anak dari Kanaan (Kej. 10:15).

2. והגרוגשי (orang Girgasi). Bangsa Girgasi merupakan suku yang termasuk dalam daftar keturunan Kanaan (Kej. 10:16; 1Taw. 1:14) dan bagian dari penduduk tanah Kanaan yang paling bercampur-baur, seperti telah digambarkan sebelumnya dalam perjalanan Tuhan dengan Abraham (Kej. 15:21; bnd. Neh. 9:8). 
Dalam rangka penaklukan tanah Kanaan, mereka dikalahkan oleh orang Israel (Ul. 7:1; Yos. 3:10; 24:11). Lokasi suku Girgasi kurang jelas. Diduga nama itu berarti "umat perwalian Gesy" ("Gesy" adalah allah/dewa terang yang disembah di Sumeria pada milenium III s.M.). Ada pula ahli yang mengaitkan "Girgasi" dengan "Gerasa" (Mar. 5:1). Menyimak pada sastra Ugarit Kanaan Utara (abad ke-14/13 s.M.), orang Girgasi secara tidak langsung dapat diketahui dari dua nama sebutan: grgsy dan bn-grgsy, yaitu Girgas dan Ben-Girgas. Girgas yang disebut Alkitab dan Ugarit mungkin berbeda dari suatu bangsa di Asia Kecil yang dikenal sebagai Karkisa dalam sejarah orang Het dan "krksy" dalam catatan Mesir.

3. והארי (orang Amori). Bangsa Amori adalah penduduk Kanaan (Kej. 10:16) yang sering terdengar bersama orang Het, orang Feris dan lainnya sebagai lawan orang Israel (Kel. 33:2). Mereka terpencar di seluruh daerah berbukit di seberang Sungai Yordan. Abram bersekutu dengan orang Amori dari Hebron dan dengan bantuan mereka mengalahkan keempat raja yang menyerang dataran Laut Mati, termasuk kota orang Amori, yakni Hazezon-Tamar (Kej. 14:5-7). Nama itu juga dipakai sebagai istilah umum untuk seluruh penduduk Kanaan (Kej. 48:22; Yos. 24:15). Yehezkiel dengan jelas menunjukkan penduduk Palestina yang bercampur-baur (sebagian besar disebabkan penyusupan yang terus-menerus oleh para penghuni gurun pasir) dengan melukiskan Yerusalem sebagai keturunan orang Amori dan orang Heti (Yeh. 16:3, 45). Pada pertengahan milenium III s.M. ada Kerajaan Amuru di dataran Asia, sebelah barat Mesopotamia Tengah (dalam bahasa Akad, amuru berarti "barat", dan memang bangsa itu termasuk rumpun bangsa Semit Barat-laut). Pusat kerajaan orang Amori, yakni kota Mari, dihancurkan sekitar tahun 1700 s.M. oleh Hamurabi, Raja Babel. Sesudah penyerbuan Hamurabi itu, beberapa rombongan Amuru/Amori mengungsi ke Selatan dan mendirikan kerajaan-kerajaan kecil dibeberapa tempat, 
termasuk daerah pegunungan Yehuda (Ul. 1:19) dan TransYordania (Ul. 1:4; 2:24-3:11; Yos. 2:10).

4. והפנעני (orang Kanaan). Bangsa ini adalah bangsa yang berbicara bahasa Semit dan mendiami daerah di Fenisia. Pertalian keturunan mereka hingga kini belum dapat dipastikan. Kata "Kanaan" rupanya berasal dari bahasa Huri dan, selain dari menjadi nama suku, istilah "orang Kanaan" dapat mengandung arti yang lebih terbatas, yaitu "pedagang" (Yes. 23:11; Hos. 12:7; Zef. 1:11), karena dagang mewujudkan sifat paling khas dari pekerjaan orang Kanaan. Pemakaian kata "orang Kanaan" bagi "pedagang" ini adalah suatu pemakaian yang tua: sebuah tugu dari Firaun Amenofis II (1440 s.M.) mendaftarkan di antara para tawanan Siria - 550 maryannu (= prajurit kereta perang yang terdiri dari orang-orang bangsawan), 240 orang istri mereka, 640 Kn'nw, 232 orang anak para pangeran, 323 orang anak putri para pengeran. Dari berita ini Maisler benar jika ia menyimpulkan bahwa $640 \mathrm{Kn} n w$ (orang Kanaan) yang terdapat di antara kelompok yang begitu terhormat ialah "pedagang-pedagang kaya dari pusat-pusat pantai dan perdagangan dari Siria dan Palestina".

5. (orang Feris). Detail-detail tentang suku Feris sukar dipastikan. Beberapa indikasi: [1] umumnya hidup di tengahtengah penduduk tanah Kanaan (Kej. 15:20; Kel. 3:8; Ul. 7:1; 20:17; Yos. 3:10; 9:1; Hak. 3:5; 1Raja 9:20; 2Taw. 8:7; Ezr. 9:1; Neh. 9:8); [2] bersama orang Yebus dan yang lainnya, di daerah pegunungan (Yos. 11:3); [3] bersama orang Kanaan dekat Betel (Kej. 13:7), dekat Sikhem (Kej. 34:30) dan di daerah pegunungan Yudea (Hak. 1:4 dyb); [4] bersama orang Refaim (Yos. 17:15). Rupanya mereka penduduk pegunungan. Nama ini cocok dengan pengertian "Feris", "penduduk desa". Pengertian ini lebih diutamakan oleh sebagian penafsir (dari kata peraza yang berarti "desa") daripada nama dari suatu kelompok bangsa. Bahwa dalam Kejadian 10:15 dyb orang 
Feris tidak disebut di antara anak-anak Kanaan, mendukung kemungkinan ini.

6. והחוי (orang Hewi). Hewi adalah salah seorang putra Kanaan (Kej. 10:17; 1Taw. 1:15); sejumlah penduduk Siria dan Palestina pada zaman dahulu. Disebut demikian untuk membedakannya dari orang Kanaan, Yebus, Feris, Girgasi dan Amori (Kel. 3:8; 23:28; Ul. 7:1) dan dalam persekutuan dengan orang Arki yang diketahui bermukim di Libanon (Kej. 10:17). Mereka tetap tinggal di situ pada masa pemerintahan Daud dan yang mendaftarkan mereka sesudah Sidon dan Tirus (2Sam 24:7). Orang-orang Hewi dikaryakan sebagai pekerja bagi proyek pembangunan Salomo (1Raja 9:20; 2Taw 8:7). Yang lain berdiam di Sikhem, yang perintisnya digambarkan sebagai putra Hemor, seorang putra Hewi pada masa Yakub (Kej. 34:2) dan dekat Gibeon (Yos 9:7; 11:19).

7. והיבוּסי (orang Yebus). Kemungkinannya besar bahwa orang Yebus termasuk suku bangsa Amori. Mereka menduduki wilayah di sekitar Gunung Sion sehingga memberi nama pada kota Yebus. Pada zaman Daud,kota ini menjadi Yerusalem.

Setelah melihat secara terperinci keberadaan tujuh bangsa tersebut maka harus diakui bahwa mereka adalah bangsa-bangsa yang besar dan kuat dibandingkan dengan Israel. Namun bagi umat Israel, kekuatan dan kebesaran tujuh bangsa ini sama sekali tidak membuat mereka gentar karena "Tuhan menghalau mereka”. Bukan Israel, bukan manusia yang mengerjakannya. Tuhan sendiri "berperang untuk Israel" (Yos. 10:14; 23:3; Ul. 1:30), "menyerahkan mereka ke dalam tangan Israel" (Yos. 2:24; $6: 2 ; 8: 1 ; 10: 8)$. Tanah Kanaan tidak direbut karena keperkasaan Israel tetapi tangan Tuhan sendirilah yang mengerjakannya. Umat Israel harus menyadari hal ini dan tidak terbawa dalam kebanggaan atau kesombongan atas kekuatannya sendiri (bnd. Maz. 44:3-4). 
Ayat (2) dan (3)

"dan TUHAN, ALLAHmu, telah menyerahkan mereka kepadamu sehingga engkau memukul mereka kalah, maka haruslah kamu menumpas mereka sama sekali. Janganlah engkau mengadakan perjanjian dengan mereka dan janganlah engkau mengasihi mereka. janganlah juga engkau kawinmengawin dengan mereka: anak perempuan janganlah kau berikan kepada anak laki-laki mereka, ataupun anak perempuan mereka jangan kau ambil abgi anakmu laki-laki;"

Pada kedua ayat di atas secara jelas dapat dilihat dan dirasakan adanya suatu tuntutan atau perintah yang keras untuk tidak bersikap lunak terhadap bangsa-bangsa lain. Ada tuntutan bagi umat Israel untuk bersikap intoleran terhadap bangsabangsa tersebut. Israel akan mengalahkan mereka tetapi, sekali lagi, bukan karena keperkasaan yang mereka miliki melainkan karena TUHAN-lah yang telah "menyerahkan" mereka kepada Israel. Pada ayat (2) ini kata "menyerahkan" atau ינתנם secara harfiah tampaknya mengacu pada suatu tindakan atau kegiatan penaklukan wilayah tertentu melalui proses perang atau bentrokan bersenjata antara dua atau lebih pihak yang berselisih (Kel. 7:4). Pihak yang unggul apabila ia mampu mengacaukan pihak yang kalah atau "membuat musuh lari" (Kel. 23:27; Ul. 7:23). Sesuai dengan tradisi perang maka pihak yang mengalami kekalahan (pihak yang "diserahkan") harus rela menjadi hamba dari pihak yang lebih kuat (Kej. 27:37) dan berkewajiban membayar tebusan (upeti) atau denda (Kel. 21:22, 23, 30).

Akan tetapi yang harus dilakukan oleh Israel setelah itu ternyata tidak hanya sebatas mengalahkan mereka. Namun lebih keras, yaitu menumpas mereka sama sekali. Pengertian "menumpas sama sekali" pada ayat ini secara harfiah identik dengan "membunuh memakai mata pedang sehingga tidak ada yang tinggal hidup" (Yos. 11:11-14), yang tersisa hanyalah bangkaibangkai (2Taw. 20:23-24). Dalam tradisi perang, "menumpas" juga berarti memecah-belah dan membagi-bagi wilayah kerajaan yang ditaklukkan (Dan. 11:4). ”Menumpas" atau החרם תחרים juga 
berarti "mengharamkan": di sini artinya "disediakan sebagai korban bakaran kepada Yahweh". Rupanya istilah ini berasal dari perbendaharaan kata dalam tradisi Perang Suci (Holy War). Israel tidak boleh berhubungan atau bekerja sama dalam bentuk apapun dengan tujuh bangsa yang telah disebutkan itu.

Arti utama dari kata kerja "haram" baik dalam bahasa Ibrani maupun bahasa Semit yang lain ialah "melarang seseorang atau sesuatu sehingga tidak boleh didekati atau dipakai umum", "memisahkan seseorang atau sesuatu untuk dikhususkan menjadi milik ilahi". Maka sering terjadi bahwa dalam rangka menjalankan herem ini orang atau sesuatu yang dijadikan milik ilahi itu dimusnahkan dan dibakar sebagai korban (Im. 27:28). Itu terjadi terutama bila musuh yang dikalahkan dalam perang dianggap (beserta dengan kota dan harta miliknya) sebagai milik allah lain. ${ }^{48}$ Terjadi semacam perang kosmik (cosmic war). Dalam keadaan demikian dianggap patut kalau rampasan tersebut dipersembahkan kepada allah pihak pemenang (dalam hal ini Yahweh, Allah Israel) sebagai pengakuan keunggulanNya sekaligus tanda syukur atas penyertaan-Nya selama perang berlangsung. Menarik bahwa pengarang Deuteronomi tidak mengutamakan fungsi herem sebagai korban tetapi sebagai suatu tindakan tegas yang harus diambil supaya Israel jangan tergoda meniru adat paganisme orang Kanaan. Untuk memperoleh pengertian yang lebih tepat perlu dilihat apa latar belakang tindakan ini: 49

1. Mazhab Ulangan melihat masa pendudukan Kanaan sebagai masa darurat saat Israel terpaksa harus bertindak dengan memakai kekerasan. Raja-raja tujuh bangsa itu telah mulai berperang melawan Israel (Yos. 10:3-6) sehingga tidak ada pilihan lain bagi umat Israel: mengalah lalu punah dan menjadi budak kembali, atau menerima tantangan itu dan membela diri sekuat tenaga.

2. Perintah TUHAN untuk menumpas tujuh bangsa Kanaan itu dapat dimengerti dengan lebih baik apabila dapat menyelami 
besarnya bahaya rohani yang pernah dihadapi Israel, ratusan tahun sesudah mereka masuk ke negeri itu. Hidup berdampingan dengan damai di antara masyarakat Kanaan, berarti hidup berdamai dengan penyembahan berhala, mencampuradukkan TUHAN dengan Baal. Jadi, bukannya penumpasan bangsa-bangsa penduduk asli sebagai siasat atau strategi untuk merebut negeri mereka melainkan pembebasan umat-Nya dari bahaya "kanaanisasi" dan "baalisasi". Itulah yang dituju oleh perintah TUHAN.

3. Penumpasan orang-orang Kanaan harus selengkapnya, supaya sumber penggodaan itu disingkirkan "sama sekali". Namun ada kalanya perintah ini tidak dilakukan dengan sungguhsungguh. Ada sebagian besar dari dunia Kanaan itu dibiarkan tetap utuh. Akibatnya, Israel harus menghadapi tantangan berat pada masa-masa yang akan datang.

Salah satu faktor yang oleh Deuteronomi dilihat dapat mempercepat proses pembauran tersebut adalah perkawinan campuran di antara anak-anak Israel dengan anak-anak Kanaan. Karena itu dalam upaya mengantisipasi kecenderungan ini maka Deuteronomi menganggap penting untuk mengangkat persoalan "kawin-mengawin" (תתחתן) ini sebagai salah satu pokok dalam peringatannya kepada umat Israel. Bila peringatan ini diabaikan maka dampaknya bukan hanya dirasakan oleh generasi Israel yang hidup sekarang tetapi juga oleh generasi atau keturunannya di masa yang akan datang.

Ayat (4)

"Sebab mereka akan membuat anakmu laki-laki menyimpang dari padaKu, sehingga mereka beribadah kepada allah lain. Maka murka TUHAN akan bangkit terhadap kamu dan la akan memunahkan engkau dengan segera."

Inilah pokok keprihatinan Deuteronomi apabila sampai peringatannya dalam ayat (3) tidak ditaati. Pada frase kalimat yang pertama tampak dengan jelas akibatnya, yaitu "mereka akan 
membuat anakmu laki-laki menyimpang dari pada-Ku". Secara konkret, "menyimpang" (כי־י-יריר) berarti: tidak sungguh-sungguh mendengarkan perintah Tuhan dan tidak beribadah kepada Tuhan sebagai wujud dari akta mengasihi Tuhan (Ul. 11:13). Bukannya menyembah TUHAN, mereka malah sujud menyembah allah lain (אלהים אחרים) yang disembah dalam wujud matahari, bulan atau segenap tentara langit (benda-benda di langit), segala hal yang telah dilarang TUHAN (Ul. 17:3).

Penyimpangan ini kemudian akan membangkitkan "murka TUHAN" dalam bentuk kutuk, timbulnya kekacauan atau huruhara dan penghajaran (Ul. 28:20). Hal ini terjadi bukan karena TUHAN membenci umat-Nya melainkan justru "murka TUHAN" (אף-יהוה) adalah salah satu ekspresi dari kasih TUHAN kepada umat-Nya. Dikatakan demikian, karena begitu besar kasih-Nya kepada Israel sehingga Ia akan merasa dikhianati bila Israel "menyimpang" dari kasih dan janji-Nya. Ungkapan ini merupakan khas PL di mana Tuhan selalu digambarkan sebagai "suami" dan Israel sebagai "istri" untuk mengungkapkan betapa dekat dan intimnya hubungan antara Allah dan umat-Nya. Bahkan sebagian besar bagian dalam PL melihat karakter Allah sebagai Allah yang cemburu (Ul. 6:15).

Kemurkaan TUHAN ini membawa akibat yang fatal, yaitu umat akan dibuang atau ditawan oleh musuh. Dengan lain perkataan, Israel selalu akan menjadi pihak yang kalah dalam setiap peperangan (1Raja 8:6).

Ayat (5)

"tetapi beginilah kamu lakukan terhadap mereka:mezbah-mezbah mereka haruslah kamu robohkan, tugu-tugu berhala mereka kamu remukkan, tiang-tiang berhala mereka kamu hancurkan dan patung-patung mereka kamu bakar habis."

Sebagai wujud nyata dari peringatan TUHAN untuk tidak mencampuradukkan TUHAN dengan Baal maka umat diharuskan untuk memusnahkan segala sesuatu yang berkenaan dengan 
kultus Baal. Beberapa saran yang digunakan dalam kultus Baal antara lain:

1. Mezbah (מזכחתיהם).

Mezbah adalah meja dari batu yang tidak dipahat (alami), yang digunakan sebagai tempat menaruh dan membakar korban bakaran (Ul. 27:5-6). Tata cara peribadahan dengan membakar korban syukur di atas mezbah tidak asing bagi bangsa-bangsa Timur Dekat Kuno, termasuk Israel. Mengamati bukti-bukti agama leluhur Israel maka akan didapati suatu agama mezbah dan doa, bukan keberhalaan. Harus diakui, ada peristiwaperistiwa tertentu yang hanya berkaitan dengan Yakub yang tampaknya seperti penyembahan berhala. Memang diperlukan beberapa pertimbangan dari berbagai sudut pandang untuk bisa menentukan apakah mezbah yang dipakai untuk mempersembahkan korban bagi Yahweh, Allah Israel, sama kapasitas dan fungsinya, dibandingkan dengan mezbah yang dipakai untuk mepersembahkan korban bagi dewa/dewi yang disembah bangsa-bangsa sekitar Israel? Karena sampai saat ini banyak interpretasi terhadap hal ini saling bertumpang-tindih. Tetapi secara jelas dan konkret akan dilihat di sini bagaimana mezbah itu sebenarnya. Ada beberapa macam bentuk mezbah antara lain:

a. Batu gunung yang dapat dipakai sebagai mezbah, misalnya: batu gunung dekat Zora yang di atasnya Menoah mempersembahkan korban (Hak. 13:19).

b. Mezbah bertanduk, ditemukan di Megido. Mezbah korban bakaran di Israel mempunyai empat buah tanduk yang berfungsi untuk dibubuhi darah dari korban penghapusan dosa (Kel. 29:12; Im. 4:7, 25, 30, 34; 8:15; 9:9; 16:8) dan sebagai lambang pendamaian. Siapa yang tidak dengan sengaja melakukan pembunuhan, boleh memegang tanduktanduk mezbah itu (1Raja 1:50; 2:28). Menajiskan tanduktanduk mezbah itu berarti menajiskan seluruh mezbah (Am. 3:14; Yer. 17:1). 
2. Tugu-tugu berhala (וּמצ:בתםם).

Tugu-tugu dipakai di Palestina untuk beberapa maksud: sebagai tanda penghormatan untuk pahlawan, perbatasan tanah, peringatan peristiwa bersejarah dan sebagai sarana kultis. Rupanya yang dimaksud pada ayat ini adalah tugu-tugu berhala sebagai sarana kultis yang ditiru dari ibadah Kanaani. Pada prinsipnya, tugu-tugu tersebut berfungsi menentukan tempat keramat atau menghadirkan allah di tempat it. Di kuil Baal, tugu berhala Baal dan tiang berhala Assera berdiri di samping mezbah (2Raja 15:14). Tugu itu dianggap sebagai yang mewakili kehadiran dewa dalam kuil dan merupakan objek pemujaan yang agung. Ada juga tugu yang bercekung untuk menampung darah korban persembahan, dan ada kalanya, seperti kelihatan dari permukaannya yang kena gosok karena dicium oleh pemujanya (bnd. 1Raja 19:18). Atau, tugu tersebut mungkin melambangkan hasrat penyembahan laki-laki untuk hadir di tempat keramat sehingga melalui alat tersebut kehadiran allah "dirangsang".

3. Tiang-tiang berhala (ואשירהם).

"Assera" adalah nama dewi kesuburan dalam pantheon Kanaani. Nama "assera" juga dipakai untuk menyebutkan alat kultis yang menandai dewi tersebut. Tiang assera rupanya terbuat dari bahan kayu (Ul. 16:21) yang diketahui dari cara menghancurkannya, yaitu dengan membakar (Ul. 12:3; 2Raja 23:6). Mungkin sekali kayu itu berasal dari pohon yang dianggap keramat dan yang selalu berdaun hijau, lambang dari kehidupan dan kesuburan. Kalau tugu berhala merepresentasikan kehadiran dewa maka tiang berhala merepresentasikan kehadiran dewi. Adanya tugu dan tiang bersama-sama dalam kultus rupanya menjadi simbol kesuburan yang dapat membuka kesempatan bagi suatu "pelacuran bakti" dan praktik-praktik agama kesuburan yang lain. Semua praktik itu pada prinsipnya bertentangan dengan Yahwisme karena agama kesuburan merupakan usaha untuk 
menundukkan kuasa-kuasa ilahi, yang laten dalam alam, kepada kehendak manusia. Sedangkan Yahweh bukanlah kuasa alamiah melainkan pencipta alam (termasuk manusia), sehingga beribadah kepada Yahweh berarti menundukkan diri manusia kepada kehendak Yahweh. Perikop ini merangsang pemikiran tentang hubungan antara iman Yahwisme dan kebudayaan setempat. Sikap mazhab Ulangan terhadap kebudayaan Kanaani, pada satu pihak, ternyata negatif sekali. Hal ini dapat dimengerti dengan menyadari konteks kehidupan Israel pada saat itu yang di dalam kenyataan pada zaman rajaraja umat Israel pernah mengalami suatu krisis yang hebat, dimana identitasnya makin kabur dan terancam oleh pengaruh dunia orang Kanaan di kalangan mereka sendiri. ${ }^{50}$ Namun, di lain pihak, terdapat kecenderungan yang kuat di Israel untuk memanfaatkan atau mengadopsi bahkan "me-Yahweh-kan" kebudayaan Kanaani. Kecenderungan dan gejala seperti ini tampaknya merupakan hal yang sudah biasa di dalam interaksi bangsa-bangsa Timur Dekat Kuno.

4. Patung-patung berhala (היפיליהם).

Ada beberapa model patung yang biasa dipakai sebagai objek pemujaan, yaitu:

a. Batu berukir (Im. 26:1) yang dipahat oleh tukang pahat dengan menyerupai manusia laki-laki dan perempuan (Ul. 4:16-18).

b. Patung tuangan, yang dibuat dengan cara meleburkan logam ke dalam tuangan dan membentuknya dengan suatu alat (Kel. 32:4, 24). Disangsikan apakah patung tersebut, demikian juga patung anak lembu emas buatan Yerobeam, dimaksudkan untuk mencitrakan Yahweh ataukah dimaksudkan sebagai dasar di atas nama Dia ditahtakan. Patung tuangan ini biasanya didirikan secara tersembunyi (Ul. 27:15). 
Pada akhirnya, semua alat kultus yang disembah itu harus dihancurkan dan dimusnahkan. Barth menyimpulkan alasan pemusnahan alat-alat kultus tersebut: ${ }^{51}$

"Bukannya dewa Baal dengan pemuja-pemujanya. Bukan juga jumlah dan kuasa-kuasa orang Kanaan itulah yang membuat (nabi) itu cemas, tetapi meluasnya aliran sinkretisme yang mencampuradukkan TUHAN dengan Baal, hingga kesadaran diri dan tugas panggilan umat Israel semakin tawar jadinya."

Ayat (6)

"sebab engkaulah umat yang kudus bagi TUHAN, Allahmu; engkaulah yang dipilih oleh TUHAN, Allahmu, dari segala bangsa di atas muka bumi untuk menjadi umat kesayangan-Nya."

Setelah mengeluarkan pernyataan yang keras terhadap berbagai bentuk kultus Baal maka dalam ayat ini mazhab Ulangan memberikan suatu alasan yang menjadi dasar dari seluruh tindakan pemusnahan di atas.

Israel tidak boleh menjadi sama dengan bangsa-bangsa lain di sekitarnya karena Israel adalah umat yang kudus bagi TUHAN. Kata "kudus" (קרוש) berasal dari akar kata yang berarti "terpisah", "khusus". Allah sendiri disebut sebagai yang kudus karena di dalam hakikat-Nya, Dia terpisah dari segala mahluk atau ciptaan. Bila ungkapan ini dikenakan kepada Israel maka itu berarti umat Israel dipisahkan dan dikhususkan sebagai korban (bakaran) bagi TUHAN (Im. 2:3,10) yang bebas dari segala kenajisan (1Sam. 21:4,5); dengan demikian menjadi lambang kemuliaan bagi Tuhan (Kel. 28:2). Dalam konteks ini, yang lebih utama yaitu jika Israel diangkat menjadi umat yang kudus itu berarti Israel harus memisahkan dirinya dari penyembahan berhala (Ul. 7:16). Atau, dari sudut pandang yang lainitu berarti Israel harus menaati dengan sungguh-sungguh seluruh kehendak Allah yang mewujud di dalam hukum-hukum-Nya. Umat Israel adalah umat yang dipersiapkan hanya bagi Yahweh dan tidak boleh bersandar atau bergantung pada allah lain selain pada Yahweh sebagai satusatunya Allah bagi Israel. 
Alasan mendasar selanjutnya, yang memberikan kepada Israel suatu peranan dan posisi yang istimewa dibandingkan dengan bangsa-bangsa lain, ialah karena Israel adalah umat yang "dipilih" oleh TUHAN. Memang konsepsi bahwa Yahweh sejak mulanya telah menetapkan Israel sebagai milik-Nya khusus, merupakan salah satu tradisi Israel yang tertua: Abram dipanggil (Kej. 12:13); Musa ditugaskan (Kel. 3:10) dan seterusnya. Secara harfiah, "dipilih" mengandung pengertian: ditugaskan untuk senantiasa melayani TUHAN dan menyelenggarakan kebaktian demi namaNya (Ul. 18:5). Mungkin juga kata ini sangat erat kaitannya dengan arti "kudus".

Menarik bahwa istilah "pilih" (בּחר) baru muncul dalam tulisantulisan mazhab Ulangan walaupun konsep "pengkhususan" secara umum sudah ada sejak dulu. Oleh para pengarang Kitab Sejarah Deuteronomistis, istilah ini dipakai dalam tradisi pengangkatan raja atau pejabat istana (1Sam. 10:24; 16:8,12; 2Sam. 6:21; 1Raja 8:16; 11:34; 1Sam. 2:28). Bahan-bahan kuno ini dimanfaatkan oleh mazhab Ulangan untuk kembali mengingatkan umat Israel akan status mereka yang "khas", yaitu umat yang dipilih dan diangkat oleh Yahweh (Ul. 4:37; 7:6; 10:15; 14:2; 1Raja 3:8). Bila dicermati dalam kerangka konteks pemberitaannya maka dapatlah dipahami mengapa konsep ini kembali diangkat oleh para penulis mazhab Ulangan. Masa penyusunan Kitab Ulangan adalah masa-masa krisis.

Kerajaan Israel Utara dihancurkan oleh Asyur pada tahun 721 s.M. Sementara itu, Kerajaan Yehuda (Israel Selatan) juga dalam kondisi sosial-politik yang tidak menentu karena ancaman paganisme dan penyembahan berhala yang dipimpin oleh Raja Manasse (dalam pengaruh istrinya, Ratu Izebel). Jadi, para penulis Ulangan bergumul dan bergulat demi tetap eksisnya Israel sebagai umat Allah. Kerajaan di Utara akhirnya mengalami kehancuran, sekarang tinggal Yehuda yang harus dipertaruhkan. Untuk dapat mencapai maksud tersebut maka diperlukan suatu reformasi dan pembaruan hidup umat. Salah satunya, selain pemilihan Israel 
sebagai umat Allah, ialah ibadah Israel juga harus dipusatkan di satu tempat suci sebagai tempat yang sudah dipilih Allah (Ul. 12:2 dyb; 15-16).

Selanjutnya, dengan dikuduskannya dan dipilihnya Israel maka itu berarti Israel menjadi "umat kesayangan Tuhan". Pelabelan kata "kesayangan" (סגליה) kepada Israel ini berarti Israel merupakan "harta yang amat tinggi nilainya sehingga disayangi dan dijaga oleh Yahweh" (Kel. 19:5; Ul. 21:11; Mzm. 135:4). Kemungkinan besar istilah ini memang berasal dari mazhab Ulangan. Deuteronomi mengenakan istilah ini pada Israel dikarenakan pada konteks penyusunannya, Israel diperhadapkan dengan berbagai macam berhala serta pemujaan terhadapnya. Yahweh tidak ingin harta kesayangannya yang sangat bernilai "diambil" atau "direbut" oleh allah lain. Karena itu Deuteronomi mengingatkan seluruh umat bahwa mereka adalah harta kesayangan milik Allah yang kudus dan tinggi nilainya. Dengan demikian, hidup merekapun harus menunjukkan suatu kualitas kesucian yang tinggi nilainya dibandingkan "harta kesayangan" dari allah lain yang tidak jelas kuasanya.

Ayat (7)

"Bukan karena lebih banyak jumlahmu dari segala bangsa manapun juga, maka hati TUHAN terpikat olehmu dan memilih kamu - bukankah kamu ini yang paling kecil dari segala bangsa?"

Ada pernyataan yang menarik dalam ayat (7) ini, yang sepertinya memberi sentakan kepada Israel untuk berhati-hati agar tidak menyombongkan diri dengan statusnya sebagai umat yang dipilih dan dikuduskan bagi Yahweh. Bukan karena keperkasaan Israel maka hati TUHAN "terpikat".

Pengertian "terpikat" (חשק) yang dipakai dalam ayat ini rupanya kata yang umum dipakai di kalangan masyarakat Ibrani dan sekitarnya. Dalam konteks-konteks lain (mungkin ini yang menjadi Sitz Im Leben-nya), istilah "terpikat" ini menggambarkan rasa cinta (tertarik) dari seorang lelaki kepada seorang perempuan 
karena kecantikkannya (Ul. 21:11), bahkan ingin memiliki atau menjadikannya istri (Kej. 34:8). Dalam konteks penulisan Ulangan, dapat dikatakan bahwa di tengah desakan dan ancaman paganisme serta penyembahan kepada allah-allah asing, penulis mazhab Ulangan ingin mengingatkan umat Israel bahwa mereka harus tetap memelihara dan menjaga "kecantikannya" dengan jalan setia kepada perjanjian yang telah ditetapkan, serta menjaga kemurnian motivasi dalam beribadah kepada Yahweh. Dengan demikian, Yahweh akan tetap "terpikat" dan tidak berpaling dari Israel.

Mengapa Israel tidak boleh berbangga diri dengan kemenangankemenangan yang mereka capai dalam setiap peperangan? Deuteronomi memberikan jawaban yang sederhana namun logis, yaitu karena Israel yang "paling kecil dari segala bangsa" (המעט). Istilah ini mungkin pengertiannya dapat dibalik. Penulis mazhab Ulangan melihat bahwa Israel sebagai yang "paling kecil dari segala bangsa" bukan dari jumlah manusia, anggota umat Israel, melainkan justru karena membandingkannya dengan keberadaan bangsa-bangsa lain. Israel sebagai satu bangsa mungkin bukanlah yang "paling kecil", tetapi bila dibandingkan dengan bangsabangsa lain, Israel dapat dikatakan lebih kecil ("kecil" disini rupanya mengacu pada pengertian "kecil" secara kuantitas; atau mungkin "kecil" berdasarkan ukuran tubuh; bnd. 4:38; 7:1; 9:1; 11:23; lihatjuga 1Raja 3:8).

Ayat (8)

"Tetapi karena TUHAN mengasihi dan memegang sumpah-Nya yang telah diikrarkan-Nya kepada nenek moyangmu maka TUHAN telah membawa kamu keluar dengan tangan yang kuat dan menebus engkau dari rumah perbudakan, dari tangan Firaun, raja Mesir."

Kalau memang Israel dipilih dan dikuduskan sebagai umat kesayangan Tuhan bukan karena keperkasaannya atau karena Israel pantas mendapatkannya, alasan apakah yang mendasari tindakan Yahweh dalam melakukannya? Atas pertanyaan ini, sekali 
lagi, dengan sederhana Deuteronomi memberikan jawabannya, yaitu semata-mata karena Tuhan mengasihi Israel. Hanya itu dan tidak ada alasan lainnya.

Kata "mengasihi" (מאהבת) berasal dari akar kata ('אהב ב־ה) yang merupakan istilah umum yang dipakai di kalangan masyarakat Ibrani dan digunakan pada setiap macam dan jenis jalinan kasih. Akar kata atau kata ini dapat dikenakan pada istilah-istilah dalam arti sekular dan dapat juga dikenakan dalam bidang keagamaan. Dalam pengertian sekular dapat berarti: kegemaran terhadap suatu makanan (Kej. 27:4; Hos. 3:1), kebijaksanaan (Ams. 4:6) dan pengetahuan (Ams. 12:1) dan lain-lain. Lebih khusus berkenaan dengan pribadi manusia, akar kata ini digunakan untuk menyatakan kasih antarsesama manusia (Mzm. 60:4, 5), kasih akan seseorang (1Sam. 20:17), kasih kepada sesama seperti kepada diri sendiri (Im. 19:34), kasih kepada anak (Kej. 22:2), kasih seorang lelaki kepada perempuan (Kidung Agung), kasih seorang budak kepada tuannya (Ul. 15:16). ${ }^{52}$ Jadi dapat disimpulkan bahwa (1) bila akar kata ini dikenakan pada jalinan kasih antarpribadi maka itu menunjukkan suatu sikap dari seseorang yang "lebih" (superior) kepada yang "kurang" (inferior), dan (2) bilamana dikenakan pada sikap dari seseorang yang "kurang" (inferior) kepada yang "lebih" (superior) itu merupakan kerendahan hati, yang penuh pengabdian.

Sedangkan dalam bidang kehidupan keagamaan, seperti yang terdapat pada Ulangan 4:37, dapat dicatat bahwa kasih Tuhan kepada nenek moyang berkembang menjadi kesetiaan kepada keturunan mereka. Namun, di sini justru malah sebaliknya: kasih Tuhan kepada umat-Nya berakar dalam kesetiaan-Nya kepada nenek moyang mereka (Ul. 7:13; 10:15). Ada beberapa hal yang dapat dikenali sebagai karakteristik dari kasih Tuhan:

ditandai dengan keintiman, dikaitkan dengan "pemilihan", spontan tak beralasan, rela (tak bersyarat), berakar dalam kesetiaan, tak dapat dipisahkan dari kebenaran-kesuciaan, menuntut kesetiaan yang utuh, 
karena benar dan suci maka kasih Tuhan juga mengandung akta penghukuman dan koreksi. ${ }^{53}$

Dalam konteks penulisan Ulangan dimana Israel diperhadapkan dengan ancaman paganisme dan sinkretisme agama, pernyataan "TUHAN mengasihi kamu" ini sebenarnya dipakai oleh penulis untuk tetap mengingatkan umat bahwa Allah Israel adalah Allah yang unik, yang lain dari pada yang lain. Keunikannya terletak pada keinginan dan kemampuan-Nya untuk mengasihi Israel tanpa syarat dan tanpa alasan, tanpa memandang kedudukan dan keberadaan Israel. Inilah yang tidak dapat dilakukan oleh allah-allah lain yang disembah dalam kesia-siaan oleh bangsabangsa pagan. Karena itu melalui pernyataan ini, penulis ingin menyampaikan nasihat bahwa tidak ada untungnya berpaling dari Yahweh dan menyembah allah seperti itu.

Salah satu wujud nyata dari kasih Tuhan kepada Israel yang telah dirasakan sendiri oleh umat ini, yaitu tindakan Allah yang "menebus" Israel dari "rumah perbudakan". Kata kerja "menebus" (ויפדיד) ini mempunyai arti yang luas, sehingga dapat dipakai bukan hanya untuk urusan penebusan seorang budak saja, tetapi juga untuk penebusan harta-milik dari kekuasaan yang berhak menahannya (Kel. 13:13), bahkan juga untuk "penebusan" atau penyelamatan seseorang dari bahaya dan kesesakan (2Sam. 4:9; Mzm. 78:42; 119:134 dan seterusnya). Di dalam hal penebusan seorang budak, tampaknya kata kerja ini mula-mula hanya digunakan apabila penebusan itu dilakukan dengan sukarela, jadi bukan karena kewajiban berdasarkan hubungan kekeluargaan dengan si budak itu. Akan tetapi perbedaan antara "penebusan wajib" dan "penebusan sukarela" itu tidaklah lagi dirasakan apabilan Tuhan dikatakan "menebus" umat-Nya dari tangan orang Mesir. Pemakaian istilah "menebus" di sini menekankan bahwa:

1. Israel menjadi bebas (hanya) karena tindakan Yahweh; 
2. Pembebasan tersebut bukanlah suatu akta murahan melainkan ada "harga" yang sudah dibayar oleh TUHAN selaku Allah Israel;

3. Dengan ditebusnya Israel maka itu berarti Israel adalah milik sah dari TUHAN.

Ayat (9)

"Sebab itu haruslah kau ketahui, TUHAN, Allahmu, Dialah Allah, Allah yang setia, yang memegang perjanjian dan kasih setia-Nya terhadap orang yang kasih kepada-Nya dan berpegang pada perintah-Nya, sampai kepada beribu-ribu keturunan,"

Dalam ayat ini secara eksplisit ada seruan yang mengingatkan umat akan segala sesuatu yang telah Tuhan lakukan untuk mereka di sepanjang sejarahnya. Walaupun umat seringkali murtad dari kesetiaannya kepada Tuhan, namun Tuhan tetap setia. Kata sifat "setia" (הנפמו) di sini secara harfiah berarti "teguh" (1Sam. 25:28), "tidak bergoyah" hingga dapat "diharapkan" dan "diandalkan" (Bil. 12:7). Bila pernyataan ini diperhadapkan dengan konteks penulisannya maka rupanya penulis mazhab Ulangan memakai dan memanfaatkannya dalam rangka menghibur serta memberi kekuatan kepada segenap umat Israel, bahwa di tengah situasi kehidupan sosial, politik, ekonomi dan keagamaan yang tidak menentu akibat kuatnya cengkeraman dan penindasan Asyur, umat diharapkan tetap memegang teguh perjanjian mereka dengan Tuhan. Karena pada hakikatnya Tuhan juga setia dan teguh kepada perjanjian yang telah dibuat-Nya mulai dari nenek moyang Israel sampai keturunan-keturunannya. Di atas dasar kesetiaan Tuhan inilah umat harus berdiri dan bergantung serta mengandalkan Dia. Selain itu, Tuhan tidak hanya setia memegang perjanjian-Nya dengan umat Israel tetapi Ia juga melakukan "kasih setia" terhadap umat-Nya, Israel.

Asal-usul etimologis kata ini tidak begitu jelas. Biasanya dimengerti sebagai "belas kasihan" (Ayb. 6:14); "kemurahan" (Kej. 19:19; Kel. 15:13; Ul. 5:10); "kebaikan" (Yos. 2:12, 14; Hak. 
8:35; 1Sam. 15:6; 20:8; 1Raja 2:7). "Kasih setia", yang biasanya diterjemahkan dengan "kemurahan" ini menimbulkan kesan yang seakan-akan berlainan atau malah bertentangan dengan "keadilan". Allah melakukan "kasih setia" (והחסר), sebenarnya berarti Allah bertindak tetap setia sesuai dengan hukuman perjanjian yang ditetapkan-Nya sendiri. "Kasih setia" Allah bukanlah pengecualian dari keadilan-Nya melainkan sebaliknya adalah pelaksanaan yang wajar dari keadilan-Nya itu. Melakukan "kasih setia" atau "kasih" dan "setia" adalah inti keadilan-Nya, dan bukan suatu kemurahan istimewa di luar keadilan itu.

Ayat (10)

"tetapi terhadap diri setiap orang dari mereka yang membenci Dia, la melakukan pembalasan dengan membinasakan orang itu. la tidak bertangguh terhadap orang yang membenci Dia. la langsung mengadakan pembalasan terhadap orang itu."

Di dalam ayat (10) ini tampak sisi lain dari kasih setia Allah. Kasih setia yang mewujudkan dirinya dalam bentuk keadilan. Kalau dalam ayat (9) dikatakan bahwa Allah akan setia apabila umat Israel juga setia kepada Allah dan, sekarang dalam ayat (10), dikatakan bahwa Tuhan akan melakukan "pembalasan" kepada mereka yang membenci Dia. Di sini seolah-olah kelihatan prinsip

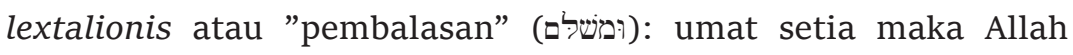
setia, umat tidak setia maka Allah juga tidak setia. "Pembalasan" yang dilakukan Allah bukanlah karena Allah tidak setia melainkan justru karena "kesetiaan" Allah. Di dalam kesetiaan Allah inilah, Ia menghukum umat yang tidak setia. Di sinilah "kesetiaan" dan "keadilan" Allah hadir bersamaan tanpa saling bertentangan.

Ayat (11)

"Jadi berpeganglah pada perintah, yakni ketetapan dan peraturan yang kusampaikan kepadamu pada hari ini untuk dilakukan."

Perikop ini ditutup dengan suatu anjuran untuk berpegang pada "ketetapan" dan "peraturan" yang telah Allah sendiri sampaikan. "Peraturan" (המשפטטים) dengan kata dasar מששפט dapat diartikan 
sebagai "cara yang benar bagi seseorang untuk membawakan diri" dan "cara yang benar untuk memperlakukan orang lain". Perangai atau tingkah laku ini dapat dipaksakan secara hukum. Proses menyatakan hak perseorangan ialah keadilan dan jika seseorang melakukan kejahatan maka haruslah dia mendapat hukuman. Hak-hak Allah terwujud dalam undang-undang yang diberikan-Nya kepada manusia. Misypat berarti juga keputusan yang tepat, yang diberikan mengenai masalah-masalah yang sukar, (khususnya Urim dan Tumim). Secara luas dapat dilihat artinya: hak (Kel. 23:6; Ul. 10:18; Yes. 49:4); keadilan (Kej. 18:19; Ul. 6:19; 2Sam. 8:15; Ayb. 8:3; Yes. 1:17); penghukuman (Mzm. 105:5; Yer. 51:9; Hos 5:1); peraturan (Kel. 21:1; Ul. 4:1; Yeh. 5:6); hukum (Mzm. 19:11; 103:6; 119:7 dll); keputusan (Kel. 28:15; Bil. 27:21; Ul. 17:8-0; 1Raja 3:28).

Bila kata ini dicermati di dalam kerangka konteks yang membingkainya maka dapat dimengerti bahwa di tengah berlangsungnya berbagai sistem kehidupan sosial dan masyarakat yang selalu cenderung kepada praktik-praktik ketidakadilan sosial dan penindasan terhadap rakyat yang lemah, penulis mazhab Ulangan sejak awalnya menegur dan mengingatkan seluruh umat agar kembali melihat nilai-nilai yang terkandung di dalam segenap hukum dan peraturan yang telah Tuhan berikan.

\section{Paradigma Umat Pilihan Allah dalam Ulangan 7:1-11}

Harus diakui bahwa perikop Ulangan 7:1-11 benar-benar menampilkan suatu sosok umat yang sangat partikularistik, yang lain dari pada yang lain. Umat yang berjuang dalam membenahi kehidupannya di tengah-tengah pergolakan sosial-politik dan keagamaan yang tiada pernah berhenti. Dalam pergelutan mencari sosok jati dirinya, Israel diperhadapkan dengan berbagai fenomena dan persoalan yang terus-menerus menantang kepada suatu sikap pengambilan keputusan etis yang tepat.

Pada satu sisi, Israel harus memegang teguh perjanjian yang telah dilakukannya dengan Yahweh, Allah Israel. Perjanjian Israel 
dengan Yahweh bukanlah suatu perjanjian sekadar perjanjian dari kedua belah pihak demi kepentingan diri masing-masing. Bagi Israel, perjanjian itu pada hakikatnya identik dengan Israel itu sendiri. Sikap itu jelas terlihat dalam seluruh pergumulan sejarah Israel. Perjalanan panjang sejarah Israel terus-menerus dan selalu menjadi semacam alarm yang mengingatkan Israel akan perjanjiannya dengan Yahweh ketika Israel mulai menyimpang dan tidak setia. Dengan alasan itulah maka sebagian besar penulis dan penyusun kitab-kitab dalam PL selalu memanfaatkan kewibawaan perjanjian Yahweh-Israel untuk terus mengingatkan Israel sebagai satu umat yang dipilih oleh Allah, apabila ternyata cara hidupnya lebih cenderung kepada penyelewengan terhadap hukum-hukum Allah.

Akan tetapi, pada sisi lain, kehidupan Israel sebagai suatu bangsa juga adadi dalam proses perkembangan dan perubahan yang dinamik. Israel berinteraksi dengan berbagai bangsa ketika memasuki fase kehidupan bermasyarakat dan bernegara dengan sistem yang lebih kompleks dan terorganisir. Agar sistem (pemerintahan, perdagangan, sosial masyarakat, militer, keagamaan) tersebut dapat lebih efektif terlaksana maka satusatunya jalan adalah Israel harus beradaptasi dengan kebudayaan bangsa-bangsa sekitar, berasimilasi dengan berbagai suku bangsa yang berbeda latar belakang ketika harus melakukan negosiasi-negosiasi perdagangan guna membangun kehidupan perekonomian; mengadopsi sistem pertahanan dan keamanan yang biasa diterapkan di antara bangsa-bangsa sekitar guna merancang strategi militer yang solid. Dengan demikian, juga membuka peluang bagi masuknya nilai-nilai maupun tata cara peribadahan agama-agama asing, yang membawa Israel pada suatu gejala sinkretisme antara agama Yahweh dengan agamaagama asing tersebut. Lebih jauh lagi, nilai-nilai agama asing tersebut ada kalanya lebih mendominasi kehidupan keagamaan Israel dan menggeser posisi, serta kewibawaan agama Yahweh. 
Jadi, Israel benar-benar diperhadapkan dengan dua pilihan yang sulit. Karena itu wajarlah bila kemudian timbul berbagai reaksi. Reaksi-reaksi tersebut biasa munculnya sebagai langkah antisipasi menjaga kewibawaan agama Yahweh tetapi dalam semangat nasionalisme membangun negara. Israel melihat bahwa semangat pemurnian agama Yahweh itu harus dilihat sebagai yang menjiwai nasionalismenya. Dengan lain perkataan, suatu gerakan nasionalisme yang muncul itu sebenarnya hanya "bayangan" dari wujud yang sesungguhnya, yaitu semangat pemurnian dan penegakan kembali agama Yahweh. Gerakan nasionalisme hanyalah asap dari bara yang menyala dalam tumpukan jerami.

Perikop Ulangan 7:1-11 dalam pergumulan dengan konteks menempatkan konsep "perang" sebagai konsep sentral dalam gerakan pemurnian agama Yahweh. Bangsa-bangsa (disebut tujuh bangsa) tersebut harus benar-benar ditumpas habis karena bila mereka dibiarkan maka kelak akan menjadi ancaman yang akan mempengaruhi seluruh generasi keturunan Israel untuk berpaling dari Yahweh. Mazhab Ulangan rupanya mengangkat dan memunculkan kembali konsep "perang" dari tradisi Perang Yahweh, yang oleh para penulis Ulangan diberi bentuk yang lebih modern dan disebut Perang Suci (Holy War).

Tetapi konsep "perang" yang tampak secara eksplisit dalam kerangka Ulangan 7:1-11 ini bukanlah semangat purifikasi yang eksklusif dan membabi-buta. Justru ini merupakan esensi dari hubungan perjanjian antara Allah dengan Israel. Seperti yang dikemukakan oleh Roland de Vaux: 54

"It is incompatible with the idea of Yahwism as the particular religion and the peculiar possession of the chosen people. But, precisely because of this essential relation between the people and its God, all the institution of Israel were invested with a sacred character, war just as much as kingship or legislation."

Jadi, semangat "perang" dalam Ulangan 7:1-11 yang diterapkan Israel sebagai umat pilihan Allah ini sekali-kali jangan dilihat sebagai semangat keagamaan an sich. Justru nuansa etis dalam 
perikop ini harus dilihat sebagai perpaduan yang harmonis dari dua pilihan yang dihadapi Israel seperti tersebut di atas. Ini merupakan suatu ide yang mendasari pengambilan keputusan etis yang tepat. Keduanya tidak boleh dilihat secara fragmentaris, yang berdiri sendiri. Artinya, semangat purifikasi agama Yahweh dipahami terpisah dari semangat nasionalisme maupun sebaliknya. Karena kedua semangat ini sudah melebur dan terintegrasi secara utuh dalam seluruh konsepsi kehidupan Israel selaku umat pilihan Allah.

Israel berperang bukan hanya demi agamanya tetapi juga demi eksistensinya, di tengah-tengah perjumpaannya dengan berbagai kebudayaan dan agama bangsa-bangsa sekitar. De Vaux menegaskannya:"This does not mean that every war was a religious war, aconcept which does not appear until very late, under the Maccabees: Israel did not fight for its faith, but for its existence". 55

Jadi "perang" dalam kerangka perikop di atas bisa juga diartikan sebagai perjuangan demi penegakan eksistensi sebagai umat pilihan Allah. Gagasan ini memang sangat kentara dalam seluruh Kitab Ulangan. Sebagaimana dikemukakan oleh Clements: "the existence of Israel as a Holy people is a Basic presupposition of everything that Deuteronomi has to say, and has undoubtedly influenced the form of the book as an address to the nation." 56

Itu berarti, Ulangan 7:1-11 menonjolkan suatu paradigma umat pilihan Allah yang inklusif. Umat pilihan Allah yang berjuang dengan semangat keagamaan yang tinggi bukan semata-mata demi diterimanya agama tersebut melainkan demi eksisnya kehadiran mereka yang unik dan khas dibandingkan dengan bangsa bangsa lain.

Melihat konsep umat pilihan Allah dalam suatu kerangka yang paradigmatis memang merupakan suatu kategori yang sangat penting dan bermanfaat bagi pemahaman dan penerapan etis seluruh PL, secara khusus Ulangan 7:1-11. Dengan melihat 
kehidupan sosial, lembaga-lembaga dan hukum-hukum Israel secara demikian maka dapatlah terhindar dari dua "bahaya".

Pada satu pihak, itu berarti tidak meniru masyarakat Israel secara harfiah. Karena memang pada dasarnya hukum sosial masyarakat kuno tidak dapat diterapkan begitu saja dalam dunia modern. Akan tetapi, pada pihak lain, sistem sosial Israel tidak dapat diabaikan dengan menganggapnya relevan hanya bagi Israel yang historis selaku umat pilihan Allah dan sama sekali tidak dapat dikenakan pada kehidupan umat selaku gereja dan manusia pada umumnya. ${ }^{57}$ Selalu saja akan ditemukan nuansa-nuansa teologis yang sarat maknanya bagi kehidupan bergereja kini dan yang akan datang, dalam masyarakat dan konteksnya masing masing.

\section{Catatan Akhir:}

27 Ernest W. Nicholson, Deuteronomy and Tradition (Philadelphia: Basil Blackwell, 1967), 58.

28 John Bright, A History of Israel (London: SCM Press, 1960), 299.

29 Nicholson, Deuteronomy and Tradition, 69.

30 Nicholson, Deuteronomy and Tradition, 59-60.

31 Nicholson, Deuteronomy and Tradition, 59-60.

32 Lih. David F. Hinson, Sejarah Israel (Jakarta: BPK Gunung Mulia, 1991), 164.

33 Nicholson, Deuteronomy and Tradition, 68.

34 F.F. Bruce, Israel and the Nations: the history of Israel from the Exodus to the Fall of the Second Temple (New York: Intervarsity Press, 1998), 62-63.

35 Bruce, Israel and the Nations, 62-63.

36 Nicholson, Deuteronomy and Tradition, 84; Lih. Gerhardvon Rad, Deuteronomy: A Commentary (Westminster: John Knox Press, 1966), 24.

37 Van der Weiden, "Hidup Bermasyarakat dalam PL", 51.

38 Bruce, Israel and the Nations, 70-73.

39 Nicholson, Deuteronomy and Tradition, 102.

40 Roland De Vaux, Ancient Israel: Its Life and Institution (Grand Rapids: W. B. Eerdmans, 1997), 338.

41 Cairns, Tafsiran Kitab Ulangan 1-11, 3-4; Lihat juga struktur Kitab Ulangan yang disusun oleh Nicholson, Deuteronomy and Tradition, 18-19.

42 Nicholson, Deuteronomy and Tradition, 19-20. 
Cairns, Tafsiran Kitab Ulangan 1-11, 13-14. Juga uraian dalam Gerhardvon Rad, Old Testament Theology. Vol. 1 (Louisville: Westminster John Knox,2001), 223.

44 Lih. Werner H. Schmidt, Introduction to the Old Testament (London: SCM Press, 1984), 129-135.

45 Hukum yang lebih tua memakai kata ganti "engkau" dalam bentuk tunggal, sedangkan Deuteronomi memakai bentuk jamak. Schmidt mempertanyakan: Apakah hal ini merupakan indikasi adanya pengaruh nabi-nabi yang jarang menunjukkan pemberitaannya kepada individu melainkan kepada umat sebagai keseluruhan (Hos. 2:2dII)?

46 Apakah fakta ini menggambarkan tidak hanya situasi penulisan (Israel pada zaman Musa) tetapi juga situasi historis pada masa Yosia yang melihat kesatuan Utara dan Selatan, atau pengharapan kenabian (Hos. 1:10—2:1; Yeh. 37:15 dyb)?

47 "This idea of election, the very term for which, as we have already said, is acreation of Deuteronomy's, is more than once expressed very radically - Israel is no imposing people, but rather the least of the people; the one and only reason for the election is the love of Yahweh" (Deut. 7:7-9). Gerhardvon Rad, Old Testament Theology. Vol. I, 223.

48 Mereka ini termasuk dalam golongan orang miskin (lih. UI. 44:29; 16:11,14; 26:12 dyb). Dipertanyakan juga apakah mereka (kelompok) ini termasuk para pengungsi yang masuk ke Selatan setelah kejatuhan Utara?

49 Gerhardvon Rad, Deuteronomy: A Commentary (Westminster: John Knox Press, 1966), 67-68.

50 Christoph Barth, Theologia Perjanjian Lama 2 (Jakarta: BPK Gunung Mulia 1991), 22-23.

51 Barth, Theologia Perjanjian Lama 2, 21.

52 Barth, Theologia Perjanjian Lama 2, 21.

53 Norman H. Snaith, Distinctive Ideas of the Old Testament (Philadelphia: Westminster Press, 1946), 168.

54 Cairns, Tafsiran Kitab Ulangan 1-11, 146.

55 De Vaux, Ancient Israel: Its Life and Institution, 258.

56 R. E. Clements, God's Chosen People (London: SCM Press, 1969),34.

57 Christopher Wright, Hidup Sebagai Umat Allah: Etika PL (Jakarta: BPK Gunung Mulia, 1993), 43-44. 


\section{Bab 3 \\ Panggilan Teologis-Etis Umat Pilihan Allah}

\section{Pengantar}

ebelum melangkah lebih lanjut sebagai upaya mencari dan

menemukan esensi nilai-nilai etis dalam relevansinya dengan kehidupan umat Kristen (Gereja) pada masa kini maka diperlukan suatu kesadaran yang jernih bahwa ketika seseorang membaca teks PL, baik dengan memanfaatkan perangkat interpretasi ilmiah maupun dengan pemahaman sebagai seorang biasa, sesungguhnya ia sedang dibawa menjelajahi "rimba belantara" dialektika teks dan konteks yang kompleks. Setiap pembaca teks PL akan berhadapan dengan kepelbagaian dan kekayaan bahan yang sarat dengan gagasan-gagasan teologis. Kenyataan yang sama juga akan dihadapi dalam proses merekonstruksi sistem etika Israel Kuno karena terlalu variatifnya bahan-bahan dalam PL sehingga memberi kesan bahwa masyarakat Israel Kuno amatlah kaya dalam kepelbagaian sikap dan praktiknya.

Menurut John Barton, kekayaan dan kepelbagaian tersebut harus dicermati dalam dua faktor: ${ }^{58}$

1. WAKTU. Ada sejumlah bidang keprihatinan moral yang hampir pasti harus diperhitungkan dengan perubahan dan perkembangan dari abad ke abad dalam sejarah Israel yang panjang. Tampaknya ada banyak kebiasaan, yang relatif tidak 
penting atau bahkan lenyap pada periode sebelum pembuangan ke Babel pada abad ke-6 s.M., yang berubah menduduki tempat utama dari minat etika pada masa pasca-pembuangan. Sebagian norma perilaku etika muncul dan lenyap dalam cara begitu rupa sehingga orang tidak dapat dengan mudah berbicara tentang perkembangan, apalagi kemajuan, tetapi hanya tentang variasi.

2. KELOMPOK SOSIAL. Relatif sedikit yang dapat dikatakan dengan tegas mengenai sosiologi Israel Kuno. Meskipun dibicarakan secara umum tentang "suku", "keluarga" dan "klan", serta tentang stratifikasi sosial dalam pengertian "penguasa", "administratur", "ahli Taurat", tentang "imam", "nabi" dan "orang-orang bijaksana", hanya ada tolok ukur yang kasar untuk membedakan dan menggambarkan berbagai kelompok ini. Kendati masuk akal bila menyebut mereka semua sebagai "Yahudi" karena semuanya mengungkapkan ketaatan dasar kepada Torah, fokus perhatian moral mereka amatlah bermacam-macam.

Sangat disadari bahwa studi ini tidak berkompeten untuk membahas etika PL secara mendalam dan menyeluruh. Apa yang telah dikemukakan oleh Barton di atas setidak-tidaknya menjadi sinyalemen bahwa sekali PL dibaca dengan kritis, sulit menganggapnya sebagai dukungan yang bersuara tunggal bagi suatu jenis etika Kristen atau Yahudi tertentu atau yang lainnya. Mau tidak mau harus ada pengakuan bahwa PL tidak dapat dipaksa untuk membenarkan keseluruhan sistem hukum gereja pada masa yang lebih kemudian, atau menunjukkan jalan yang paling jelas dalam soal-soal yang diperdebatkan sekarang ini. ${ }^{59}$ Dengan lain perkataan, seseorang akan terbawa dalam arus-arus pemikiran dilematis dan kontradiktif bila dengan sewenangwenang memanfaatkan teks-teks PL sebagai teks-teks bukti yang memberi pengesahan atas perilaku etis dan/atau tidak etis dalam konteks kehidupan di masa kini. 
Cara terbaik untuk menghampiri sistem etika PL sebagai Torah adalah mengingat bahwa maksud PL yang terutama bukanlah memberi informasi mengenai moralitas melainkan untuk memberikan bahan-bahan yang, apabila direnungkan dan diresap ke dalam pikiran, akan memberikan kesan tentang pola atau bentuk cara kehidupan yang dijalankan di hadapan Allah. Jadi untuk bentuk akhir PL, perilaku moral praktis berkaitan erat dengan apa yang kita sebut "spiritualitas": masalah gaya hidup, bukan aturan-aturan khusus dalam urusan-urusan moral. ${ }^{60}$

Dengan demikian, studi ini pada dasarnya hendak mendialogkan secara dialektis-kritis bacaan terhadap suatu teks yang terbentuk dalam suatu konteks spasio-temporal yang khas dengan realitas kontekstual dari para pembaca teks tersebut yang menghidupi suatu konteks spasio-temporal yang berbeda dan juga khas. Dialog yang dialektis-kritis tersebut bertujuan untuk memahami konstruksi teks yang kemudian mendapat legitimasi teologis sebagai "teks-teks suci" (sacred texts) yang mendasari dimensi religiositas suatu agama (dalam hal ini Kristen). Bagaimanakah teks-teks keagamaan yang eksklusif semacam ini dibaca oleh orang-orang yang hidup dalam realitas sosial yang dihidupi oleh pluralitas sosial-budaya-agama? Itulah pertanyaan dasar dalam dialog teks-konteks dalam studi ini.

\section{Umat Pilihan Allah dalam Pluralisme Beragama}

Sebagai ikhtiar merefleksikan perikop yang telah dieksegese maka perlu diajukan di sini pertanyaan: "Dapatkah dan bagaimanakah bahan biblika ini menjadi masukan untuk orang-orang Kristen dan Gereja berteologi di Indonesia pada masa kini?”

Analisis eksegetik yang secara umum telah dilakukan terhadap teks Ulangan 7:1-11 memperlihatkan suatu nuansa perspektif teologis bahwa konsep umat Allah itu memang unik. Teks tersebut membentangkan suatu perspektif tentang suatu komunitas (umat) yang hadir dan menempati posisi sentral dalam sejarah bangsabangsa di Timur Tengah Kuno. Umat yang menemukan identitas 
mereka dalam hubungan dengan Yahweh, sang Allah yang telah menegakkan perjanjian dengan memiliki mereka sebagai "umat kesayangan". Sejauh umat Israel tetap konsisten dengan status keterpilihan mereka, dengan cara mempraktikkan kasih, keadilan dan perdamaian, sejauh itu pula mereka bersama-sama dengan bangsa-bangsa dan masyarakat sekitarnya turut merasakan dan menikmati kasih, keadilan dan perdamaian sebagai manifestasi berkat Allah yang konkret.

Dari situ tampak bahwa tindakan-tindakan Allah silih berganti antara universalisme dan partikularisme. Partikularisme selalu bertujuan untuk universalisme. ${ }^{61}$ Universalisme adalah refleksi dari berbagai dimensi partikular.

Namun pada kenyataan sepanjang perjalanan sejarahnya, hubungan antara Israel dan bangsa-bangsa sekitarnya selalu dinamis dan kerap diperhadapkan dengan intrik-intrik politik serta krisis-krisis sosial berkepanjangan yang menggoyahkan sendi-sendi kehidupan Israel sebagai "umat yang dipilih Allah". Dari kenyataan dan kondisi sedemikian itulah konsep umat terpilih kembali dimunculkan sebagai konsep sentral iman Israel namun dengan penonjolan yang tegas akan dimensinya sebagai umat pilihan Allah yang eksklusif, yang menyatakan keunikannya bukan karena relasinya secara esensial dengan bangsa lain melainkan karena keterpisahannya dengan bangsa lain. Pandangan bahwa Israel berbeda dengan bangsa-bangsa lain memang merupakan suatu fenomena yang wajar. Fenomena dan sentimen identitas seperti inipun dialami oleh bangsa-bangsa lain ketika mereka berhadapan dengan Israel. Sesuatu yang wajar karena setiap bangsa pasti memiliki konsep-konsep kebangsaannya dan konstruksi identitasnya sendiri yang berakar pada keragaman budaya, bahasa, agama, kondisi wilayah geografis dan sebagainya, yang mengandung ciri-ciri khas yang membedakan mereka dengan bangsa-bangsa lain. Akan tetapi, bila pada akhirnya konsep-konsep kebangsaan dan identitas yang partikularistik ini berkembang menjadi arogansi nasional yang termanifestasi 
melalui tindakan-tindakan vulgar, seperti penghacuran suatu wilayah dan penindasan rakyat setempat, tentu konsep-konsep kekhususan identitas ini tidak dapat dianggap sebagai fenomena yang wajar lagi.

Tradisi dan teologi pemilihan Israel sebagai umat Allah dalam kerangka fenomena tersebut inilah yang kemudian menjadi warisan-warisan nilai yang merasuki Gereja dan/atau Kristianitas dalam pergumulannya ketika berjumpa dengan nilai-nilai, normanorma dan institusi-institusi non-gerejawi atau non-Kristen dalam masyarakat yang plural. Perjumpaan dengan berbagai nilai yang berbeda-beda atau yang oleh pihak Gereja disebut sebagai yang "profan", tercatat dalam sejarah, pernah menyeret Gereja dalam krisis dan konflik yang berkepanjangan. Dalam kondisi demikian, Gereja membuat "jarak" dan membangun "tembok pemisah" dengan dunia (masyarakat) dan permasalahannya. Gereja mengalienasi diri dari konteks sosialnya dan menganggap dirinya sebagai societas perfecta, masyarakat tersendiri yang sempurna dan kerena itu makin menutup diri untuk menggumuli persoalan-persoalan yang digeluti oleh masyarakat umum. ${ }^{62}$

Sebagai hasil dari pemaknaan teks-teks kitab keagamaan seperti Kitab Ulangan, Gereja-gereja di Indonesia pun turut dalam konstruksi pemahaman teologis tentang eksistensi dan identitas sebagai "umat pilihan Allah", yang pada derajat tertentu cenderung negatif dan eksklusif. Konstruksi pemahaman teologis semacam ini merupakan sesuatu yang wajar apabila dicermati dalam bingkai sejarah proses masuknya Kristianitas di Indonesia. Secara sosio-historis, Gereja-gereja yang terbentuk di Indonesia berakar dari tradisi dan teologi Kristianitas yang dibawa oleh badan-badan misi Pekabaran Injil dan zending Gereja/Kristianitas Barat yang serta-merta terbawa bersamanya semangat menjajah dan menindas melalui kolonialisasi politik-ekonomi. Inilah warisan beban sejarah yang harus dipikul oleh Gereja-gereja di Indonesia dalam memasuki era masyarakat post-kolonial dalam negara-bangsa ini. ${ }^{63}$ 
Selanjutnya dalam konteks pembangunan masyarakat yang plural, perspektif yang sempit dan eksklusif dari konsepsi Gereja sebagai Umat Pilihan Allah mesti ditinjau kembali secara kritis dan diberi pemaknaan interpretatif yang mutakhir. Apalagi ketika diperhadapkan dengan kenyataan masyarakat yang pluralistik seperti Indonesia. Pluralisme dalam masyarakat ini tidak bisa dianggap remeh karena di dalamnya mengandung benih-benih potensial konflik sosial, segregasi budaya dan fragmentasi politik identitas (etnisitas dan agama), baik pada tataran vertikal (masyarakat sipil vs negara) maupun tataran horizontal terutama yang dipicu oleh interpretasi-interpretasi politik keagamaan. ${ }^{64}$ Pluralisme di Indonesia tidak saja diwarnai dengan kepelbagaian suku, ras, agama dan kepercayaan, budaya dan golongan sebagai kemajemukan horizontal tetapi juga oleh tingkat sosial dan kemampuan ekonomi, tingkat pendidikan dan stratifikasi sosial lainnya sebagai kemajemukan vertikal. ${ }^{65}$

Membaca Kitab Ulangan, khususnya pasal 7:1-11, dalam konteks demikian sekilas mengesankan adanya legitimasi dan pengakuan teologis bahwa Gereja atau orang Kristen di Indonesia mempunyai posisi dan peranan yang istimewa, serta lebih superior dibandingkan dengan kelompok-kelompok keagamaan lainnya. Secara internal, interpretasi seperti itu sah-sah saja, malah sangat penting untuk menguji kualitas keimanan yang partikular. Namun tetap harus disadari bahwa kecenderungan untuk memanfaatkan teks-teks Alkitab sebagai teks-teks bukti yang memberikan informasi terperinci bagaimana Gereja atau orang Kristen harus hidup pada masa kini, hanya akan membawa Gereja atau Kristianitas pada posisi yang terpojok dan kehilangan vitalitas serta kreativitasnya untuk memahami kehadiran dan karya Tuhan Allah yang hidup dan menyejarah.

Jadi, dalam bingkai interpretatif terhadap Ulangan 7:111, relevansi kontekstualnya dengan kehidupan Gereja dan menggereja dalam konteks masyarakat yang majemuk agama di Indonesia bukan pada aksentuasi akan keunikan umat pilihan 
Allah "bahwa Allah telah memilih Israel" (ayat 6) melainkan pada "karena Tuhan mengasihi" dan "karena Allah setia" (ayat 8,9). Jika interpretasi mengenai konsepsi umat pilihan Allah bertolak dari realitas kasih dan kesetiaan Tuhan maka itu berarti harus ada upaya pendobrakan "tembok-tembok" teologis dan doktrinal yang selama ini menghalangi Gereja membangun relasinya secara sosiologis dan teologis dengan liyan dari realitas yang berbeda.

Realitas kasih dan kesetiaan Tuhan yang mendasari pemilihan Israel itu sama besar dan bobotnya dengan realitas kasih dan kesetiaan Allah kepada bangsa-bangsa lain. Inilah realitas kasih dan kesetiaan Allah yang universal, tak terbatas dan tak terselami.

Pendekatan terhadap realitas kasih dan kesetiaan Tuhan ini sangatlah jauh dari kecenderungan untuk memproduksi bobot makna teologis pemilihan Tuhan atas Israel secara khusus kepada suatu makna teologis yang "murahan", tidak berkarakter kuat. Sebaliknya, justru dengannya Gereja dan Kristianitas dibawa pada suatu perspektif teologis yang lebih gamblang melihat karya Tuhan yang bebas bergerak menyelamatkan manusia dan alam semesta dalam sejarah. Suatu karya dan tindakan penyelamatan yang tidak mampu untuk dibingkai dengan ilmu-ilmu teologi secara sistematis dan dijabarkan dalam suatu kerangka teologis yang linear atau teologi garis lurus. Seperti yang dinyatakan oleh Choan-Seng Song: ${ }^{66}$

"... teologi yang menangkap kegiatan penyelamatan Allah dalam suatu cara yang amat tertib... Urut-urutan keselamatan yang logis ini tidak memungkinkan selaan: ciptaan, kejatuhan, pemilihan Israel, Yesus Kristus, gereja sebagai Israel yang baru dan akhirnya penggenapan terakhir, yang satu mengikuti yang lain. Garis sejarah keselamatan tidak dapat dibelokkan atau diputuskan. Saya benar-benar ragu bahwa suatu garis lurus dapat mengungkapkan kerumitan luar biasa dari kegiatan penyelamatan Allah di dalam dunia. Sebuah garis lurus menghasilkan penyederhanaan... la menjabarkan segala sesuatu yang disentuhnya, bahkan juga Allah dan apa yang Allah lakukan... Kenyataannya mengubah Allah menjadi Allah garis lurus berarti mengkarikaturkan Allah... Sebuah garis lurus menghakimi, menghukum, menghapuskan, tetapi kasih 
mengampuni, mengeloni, memeluk dan mencakup. Allah bukanlah suatu garis lurus, melainkan kasih."

Bahwa setiap agama atau aliran kepercayaan memiliki doktrindoktrin atau nilai-nilai kebenaran ilahi yang dijunjung tinggi keabsahannya, yang mengatur tata kehidupan dan etika umatnya agar dapat mencapai kesempurnaan dan kebahagiaan di "dunia seberang", ${ }^{67}$ itu tidak dapat dipungkiri. Bahkan doktrin-doktrin ini menjadi dasar tegaknya eksistensi dan identitas umat ditengah meruaknya pelbagai nilai dalam masyarakat. Diperhadapkan dengan tantangan pluralisme agama, Gereja dituntut untuk membuka diri melihat realitas kasih dan kesetiaan Allah melalui agama-agama lain. Ini merupakan suatu lompatan melampaui stigma sinkretisme yang selalu menghantui proses-proses berteologi dalam kebudayaan manusia. Suatu sikap berteologi yang dilandasi kerelaan untuk membuka diri terhadap yang baru, menginternalisasinya dalam diri, dan melakukan transformasi secara kritis. Jadi, titik krusialnya bukan apakah Gereja atau orang Kristen mempunyai suatu identitas yang kuat, melainkan sifat identitas itu. Yang penting adalah apakah Gereja atau Kristianitas mampu berkomunikasi dengan liyan, rela belajar dari liyan, dan mengembangkan keterampilan untuk mendengar. Singkatnya, apakah identitasnya bersifat terbuka atau sebaliknya tertutup? Komunikasi akan terjadi jika sudah ada identitas yang kokoh sehingga tidak ada unsur rasa takut membuka diri terhadap dan belajar dari liyan (passing over). ${ }^{68}$

Gereja membangun identitas teologisnya sebagai umat pilihan Allah yang terbuka dan komunikatif. Secara sosiologisantropologis, identitas semacam itu bukanlah sesuatu yang statis melainkan senantiasa bergerak dan berkembang, justru karena mempunyai struktur yang terbuka. Di sinilah kekhususan suatu identitas yang terbuka, yaitu kenyataan bahwa ia bergerak, selalu dalam proses menjadi, selalu mengevaluasi dan mentransformasi dirinya. Di dalam keseluruhan tindakan ini maka Gereja selaku 
umat Allah tetap pada identitas teologis dan konsisten dengan panggilan Missio Dei.

Pada sebelah lain, identitas kristiani adalah identitas yang tidak dapat dipaksakan kepada liyan, sama seperti kasih karunia Allah yang merupakan landasan kehidupan Kristen juga tidak dapat dipaksakan atau dikendalikan. Identitas ini adalah identitas yang diberikan. Gereja dan orang Kristen hidup dengan pemberian ini tetapi tidak bisa memilikinya. Apa yang Gereja atau orang Kristen terima dari Allah tidak dapat menjadi miliknya sendiri, namun tetap adalah pemberian-Nya. Oleh karenanya Gereja tidak memiliki dirinya melainkan merupakan "umat kepunyaan" dan "umat kesayangan" Allah (1Pet. 2:9; Ul. 7:6). Inti identitas tetap merupakan misteri bagi Gereja itu sendiri. Oleh karena itu, pertanyaan "siapakah aku/kita ini" merupakan pertanyaan yang tidak akan pernah terjawab. Allah yang membenarkan eksistensi Gereja dan orang Kristen di dalam Kristus, bukan Gereja yang membenarkan eksistensinya sendiri. Kesadaran ini akan menghindari Gereja dan Kristianitas dari tendensi untuk menampilkan identitas Kristennya secara keras dan agresif sebagai sesuatu yang harus terlihat.

Padahal identitas Kristen justru tampak dan terasa ketika ada kerelaan untuk berkorban, suatu masa seolah-olah identitas itu tenggelam dan tak terlihat. Bukan jalan pembenaran diri atau jalan kekuatan yang harus ditempuh melainkan jalan kenosis, pengosongan diri (Fil. 2:6-11). Justru di situ terletak identitas yang khas Kristen. Identitas yang terletak di dalam korban, bukan kerelaan untuk mengorbankan orang lain demi pengukuhan identitas sendiri melainkan dalam kerelaan untuk mengorbankan diri sendiri demi mengangkat harkat kemanusiaan liyan (sesama manusia dan alam semesta).

Identitas kristiani dari suatu komunitas atau individu merupakan pantulan dari identitas Kristus. Dengan demikian, Kristus dapat disebut sebagai paradigma realitas keterbukaan Allah. 
Kemutlakan dan finalitas keselamatan berlangsung ketika pantulan Kristus menyata dalam tindakan yang menghidupkan kebersamaan sebagai anugerah dari misteri Allah itu. Dengannya, yang dimaksud finalitas keselamatan itu merupakan iman-yangterhubung-dengan-liyan atau relational faith. Suatu pilihan beriman yang tidak egois dan triumfalistik tapi merangkul dan menghidupi sesama dan alam semesta. ${ }^{69}$

Tujuh bangsa yang harus ditumpas (ayat 1-2) dengan seluruh perangkat peribadahan mereka tidak hanya dapat ditafsirkan secara sempit sebagai kewajiban dari umat "terpilih" terhadap umat yang "tidak terpilih". Aksentuasi maknanya terletak pada "pemusnahan" berbagai bentuk anasir yang mengacaukan, merusak, memutuskan hubungan kasih dan kesetiaan Allah kepada manusia, manusia kepada manusia dan manusia kepada Allah, ${ }^{70}$ yang dalam hal ini dilihat pada dimensi realitas kemanusiaan, seperti kemiskinan, ketidakadilan sosial, kesewenang-wenangan kekuasaan yang menimbulkan konflik antarmanusia dan keserakahan yang berimplikasi pada kerusakan lingkungan hidup, serta berbagai kepincangan dan ketidakseimbangan yang terjadi kenyataan kehidupan Gereja dan masyarakat.

Pada pernyataan ini terkandung makna keterbukaan dan kejujuran serta kerendahan hati untuk mengakui bahwa realitas kasih dan kesetiaan Allah itu tidak hanya milik Gereja dan Kristianitas, tetapi milik semua manusia tanpa terkecuali. Sebagaimana yang telah Kristus sendiri nyatakan dalam seluruh hidup dan karya-Nya hingga pada peristiwa kenosis penyaliban tubuh kemanusiaanNya. Realitas kasih dan kesetiaan serta pengosongan diri (kenosis) Allah melalui Kristus itulah yang mestinya menyentak kesadaran setiap Gereja dan Kristianitas untuk tidak hanya sibuk dengan kepentingan internalnya sendiri sembari melepaskan panggilan dan tangung jawab misionernya yang utama, yaitu bersama-sama membangun suatu tatanan kehidupan beriman yang beretika, terbuka, saling belajar dan saling menghidupkan dalam konteks kemajemukan sosial-budaya masyarakat luas. 


\section{Fundamentalisme: Suatu Identitas Alternatif?}

Kecenderungan kuat yang muncul dari dalam agama-agama terutama Kristianitas - sebagai reaksi terhadap arus perubahan, sekularisme, liberalisme dan modernisme yang merambah seluruh bidang kehidupan adalah fundamentalisme. Fundamentalisme merupakan suatu paham teologis yang bermaksud memperkuat pertahanan iman (Kristen) menghadapi gempuran liberalisasi dan modernisasi yang mempertanyakan secara kritis aksiomaaksioma keimanan suatu agama dan berupaya melakukan proses demitologisasi narasi-narasi keagamaan yang dianggap sakral. Pada praktiknya, fundamentalisme tidak hanya berhenti sebagai paham teologis tapi mewujud sebagai gerakan keagamaan yang eksklusif yang cenderung tertutup dengan dalih melakukan purifikasi doktrinal dari segala bentuk perubahan.

Sebagai suatu gerakan teologis, fundamentalisme menyusup dalam struktur berpikir dan sistem kepercayaan pada setiap agama dan denominasi Kristianitas. Secara intelektual,ia merupakan sekte. Doktrin-doktrinnya, literatur, penafsiran teks-teks keagamaan (Alkitab), cara berkomunikasi, struktur berpikir dan model relasinya dengan jelas menandakannya sebagai sebuah organisme sosial yang dapat diidentifikasikan. ${ }^{71}$ Gerakan ini tampil dengan semangat membebaskan gaya hidup beragama yang makin dirasuki gejala-gejala duniawi di kalangan umat beragama; yang pada akhirnya mengikat Gereja atau orang Kristen pada berbagai perubahan yang dianggap mengancam iman dan kecenderungan pada institusionalisasi keberagamaan.

Fundamentalisme disini dimengerti sebagai gerakan pemurnian, ${ }^{72}$ yang berupaya menarik segala sesuatu kepada kehidupan beragama yang lebih sederhana seperti "masa lampau", ketika segalanya masih jelas dan murni (tekanannya pada kemurnian Alkitab dari segala bentuk kritik). ${ }^{73}$ Oleh karena itu, kaum fundamentalis berpendapat bahwa suatu posisi yang jumud dan tidak kenal kompromi cocok dengan kepentingan-kepentingan 
mereka yang terus-menerus menekankan bahwa penerimaan posisi fundamentalis adalah satu-satunya cara untuk melestarikan hal-hal yang hakiki dari iman Kristen. ${ }^{74}$

Namun, dari sudut pandang lain, kenyataan pluralisme dalam masyarakat dan perubahan-perubahan (pembangunan) menantang Gereja selaku umat Allah untuk turut merespons konteks perubahan itu dan menentukan sikap atas segala konsekuensi yang ditimbulkan oleh perubahan/pembangunan atas realitas kemanusiaan semesta. Suatu sikap yang jelas bertolak dari kesadaran dan komitmen bahwa masalah pembangunan atau perubahan sosial dan kemanusiaan bukan cuma masalah milik mereka di luar Gereja tetapi juga masalahnya karena Gereja merupakan bagian dari pembangunan atau perubahan sosial itu sendiri. Sikap ini menuntut keberanian dan ketulusan untuk menilai ulang secara kritis tradisi-tradisi teologi Kristen (dengan seluruh kandungan nilai di dalamnya) yang selama ini menjadi pilar-pilar penyangga eklesiologi Kristen dan menopang teologi dan etika menggereja dalam konteks.

Dari segi-segi tertentu, fundamentalisme tampaknya menjanjikan suatu harapan dan sikap yang pasti dalam mengantisipasi perubahan sehingga Gereja tidak mengalami disorientasi misi eklesiologisnya dan menjadi kabur identitasnya di tengah pluralitas bersama liyan. Namun, pada segi-segi yang lain, fundamentalisme ternyata menjadi sumber pelbagai ketegangan dan konflik dalam banyak aspek menggereja, seperti ajaran Gereja, hubunganhubungan organik dalam Gereja dan kepemimpinan Gereja. ${ }^{75}$

Gereja sebagai suatu entitas rohani tidak boleh terlibat dalam pengambilan keputusan-keputusan sosial-politik, demikian anggapan kaum fundamentalis. Keterlibatan sosial-politis dipandang sebagai masalah pribadi. Kaum fundamentalis pada umumnya bekerja sebagai suatu kesatuan dan tidak terbiasa bekerja dalam konteks komunitas atau masyarakat di mana berbagai suara yang berbeda didengar. Usaha-usaha yang 
bermaksud baik dari para pemimpin gereja untuk berbicara bagi gereja dalam persoalan-persoalan kemasyarakatan sering dicemooh oleh kaum fundamentalis dan menegaskan dalam diri mereka sendiri suatu komitmen bahwa sebagai suatu kelompok mereka tidak ingin menghasilkan keputusan-keputusan, rekomendasi atau rencana-rencana sebagai kontribusi visi bagi masyarakat. Dalam praktiknya, kelompok fundamentalisme menjaga identitasnya sebagai suatu kelompok yang terpisah dari komitmen-komitmen sosial-politik. Pada derajat tertentu ini merupakan manifestasi mentalitas konservatif, yang memberi daya angker pada gerakan fundamentalisme sekaligus mendorong para penganutnya menggerus kemanusiaan mereka sebagai ciptaan yang terbuka dan tersedia untuk masa depan. ${ }^{76}$

Padahal, dalam kenyataan menggereja di Indonesia, masalahmasalah sosial, politik dan kemasyarakatan seperti kemiskinan, ketidakadilan sosial, kerusakan lingkungan, demokrasi dan sebagainya, bukanlah masalah dan tanggung jawab individu semata melainkan masalah dan tanggung jawab sosial Gereja dalam kebersamaan dengan liyan. Orang miskin perlu ditolong dan diangkat dari kubangan kemiskinannya. Akan tetapi, siapa yang harus bertanggung jawab menolong mereka? Orang miskin dan yang dimiskinkan bukan hanya dari satu atau dua golongan tertentu saja melainkan mencakup sebagian besar orang tanpa memandang identitas primordial etnis dan agama mereka. Itu contoh saja bahwa tanggung jawab menggereja dalam masyarakat merupakan tanggung jawab sosial kemanusiaan. Tanggung jawab ini berakar pada missio Dei untuk berpihak pada kepedulian hakiki dan panggilan untuk menjunjung harkat kemanusiaan sebagai citra Allah, bukan sekadar tanggung jawab semu karena tuntutan-tuntutan normatif keagamaan belaka.

Hakikat missio Dei menjadi landasan eklesiologis menggereja dalam konteks masyarakat majemuk Indonesia terasa resonansinya dalam pernyataan Yesus (Mat. 25:40). Yesus tidak berkata: "Siapa yang melakukan ini kepada-Ku..., ia melakukannya kepada 
sesama. "Tetapi Yesus berkata: "Siapa yang melakukan ini... kepada sesama-Ku... ia melakukannya kepada-Ku." Pernyataan ini menegaskan bahwa kepedulian dan keprihatinan Yesus adalah kepedulian dan keprihatinan manusiawi, yang menempatkan harkat manusia secara hakiki di atas segala kepentingan sempit orang-orang tertentu atau kelompok agama tertentu. Kepedulian dan keprihatinan yang murni semata-mata karena mereka adalah sesama manusia.

Konteks pluralisme agama di Indonesia memang mendesak Gereja untuk mencari suatu identitas yang pas dan jelas sosoknya. Apalagi dalam gerak laju pembangunan dan tranformasi sosial yang cepat dalam kehidupan bermasyarakat dan berjemaat. Fundamentalisme rupanya bukan suatu identitas alternatif yang pas dalam konteks membangun Kristianitas yang mengindonesia. Paham dan sikap beragama yang fundamentalistik hanya makin mengobarkan semangat fanatisme yang memecah-belah hubungan antarkomunitas beragama. Fundamentalisme makin mengubur realitas kasih dan kesetiaan Allah kepada seluruh umat manusia, mereduksi eksistensi kemanusiaan dan esensi relasirelasi manusiawi orang-orang beriman, serta hubungan manusia dengan Allah di Indonesia. Inilah baal dan assera abad ini yang sebenarnya tidak berkenan di hadapan Allah.

\section{Umat Pilihan Allah dan Transformasi Sosial}

Sejak bersepakat menjadi satu entitas republik bernama Indonesia pada 17 Agustus 1945, masyarakat Indonesia menjalani proses pembangunan dengan seluruh dinamikanya hingga saat ini (1945-2019). Prinsip pembangunan secara ideal bertumpu pada cita-cita terwujudnya suatu tatanan masyarakat yang makmur dan berkeadilan sebagai pengejawantahan semangat kebangsaan Pancasila. Proses-proses pembangunan, baik secara material maupun spiritual, membawa sejumlah konsekuensi logis transformasi mendasar dan pergeseran paradigma dalam 
menerjemahkan nilai-nilai etika, norma-norma sosial-budaya dan tata kehidupan berbudaya masyarakat.

Transformasi dan pergeseran nilai-nilai etis itu pada dirinya mengandung nilai positif, yang membawa masyarakat kepada suatu tingkat pemahaman yang lebih utuh akan kehidupan yang lebih manusiawi. Tetapi juga nilai negatif, yang menyeret masyarakat dalam keterasingan dengan tradisi budayanya sebagai ekspresi hidupnya. Transformasi dan pergeseran nilai-nilai etika tersebut ada kalanya membawa pada hubungan-hubungan kemanusiaan yang polemik dan dilematis sebab dimaknai beragama oleh komunitas-komunitas beragama di Indonesia.

Polemik dan dilema ini tercipta karena pembangunan menuju suatu tatanan kehidupan masyarakat modern pada tataran praktis sebenarnya membutuhkan kesiapan yang menyeluruh dari masyarakat itu sendiri untuk menghadapi arus deras modernisasi yang tak terbendung. Kesiapan itu tidak hanya pada segi-segi seperti penguasaan ilmu dan teknologi praktis dalam membantu tugas sehari-hari (komputerisasi dan jaringan telekomunikasi internet, media sosial), berdirinya industri-industri raksasa termasuk industri digital - yang berdampak pada pengerahan seluruh sumber daya (alam dan manusia) guna meningkatkan kesejahteraan ekonomi dan lain sebagainya. Namun dituntut juga kesiapan mental dari masyarakat pelaku pembangunan untuk hidup sebagai manusia-manusia dengan rasionalitas modernnya tersendiri.

Budi Susilo mencatat sebelas karakteristik mentalitas manusia modern:77

1. Memiliki sikap pribadi yang terbuka

2. Memiliki dan mengembangkan sikap untuk selalu siap berubah

3. Menghargai perbedaan pendapat dalam banyak isu

4. Menghargai waktu secara tepat

5. Memperkaya diri dengan informasi

6. Memiliki kemampuan untuk merencanakan/managerial skills 
7. Menghargai keberadaan orang lain sebagaimana adanya

8. Memiliki dan mengembangkan sikap percaya pada diri sendiri

9. Menilai keterampilan teknis sebagai hal yang penting

10.Menghargai pentingnya pendidikan sebagai wahana pengembangan ilmu pengetahuan dan teknologi (IPTEK)

11. Menghargai prinsip-prinsip demokrasi

Hidup dengan pola dan mentalitas manusia modern itu juga berarti kritis menilai tradisi-tradisi yang selama ini dipegang teguh sebagai dasar pola dan mentalitas manusia tradisional. Tradisitradisi atau etos kerja/hidup mana yang harus ditinggalkan dan mana yang masih dapat dipertahankan. Penilaian kritis terhadap tradisi-tradisi ini penting sekaligus sangat rawan (sensitif) bila tidak ditanggapi dengan sikap dan mentalitas manusia modern.

Keadaan ini pada gilirannya akan membawa masyarakat (Indonesia) menuju transisi dari pola masyarakat tradisional kepada pola masyarakat modern. Proses transformasi ini tentu tidak berjalan mulus tanpa rintangan. Sebaliknya, justru menghadapi gelombang pasang-surut konflik antargolongan yang merembes ke setiap segi kehidupan bermasyarakat. Pada umumnya, menyikapi transformasi sosial dan modernisasi ada dua golongan yang kerap berkonflik.

Golongan pertama, generasi tua, lebih cenderung untuk mempertahankan nilai-nilai tradisional yang, menurut mereka, telah berfungsi sejak masa lampau menjaga keseimbangan hubungan manusia dengan alam dan interaksi sosial dengan liyan dalam masyarakat. Sementara golongan kedua, generasi muda yang progresif, melihat sudah saatnya nilai-nilai tradisional digantikan dengan nilai-nilai yang, dalam anggapan mereka, lebih maju dan modern. Kendati secara faktual pengenaan istilah "maju dan modern" ternyata tidak lebih mengacu pada penampilan luarnya saja dan sering rancu dengan konsep "westernisasi". Sementara mentalitas yang dibawanya masih tetap mentalitas manusia tradisional seperti: ${ }^{78}$ 
1. Pandangan terhadap waktu yang selalu berorientasi ke masa lalu

2. Pandangan terhadap sesama yang berprestasi secara negati

3. Mentalitas suka menerabas (tidak memiliki suatu dasar struggle for life yang manusiawi)

4. Tidak percaya pada diri sendiri

5. Mentalitas yang berorientasi vertikal (paternalistik)

Proses transformasi ini juga merebak dalam kehidupan beragama, secara khusus dalam kehidupan Gereja yang mendaku diri sebagai umat Allah. Dengan pretensi apapun, Gereja tidak dapat mengelak dari tanggung jawab untuk terlibat dalam gerak pembangunan dan transformasi sosial-budaya karena Gereja tidak berdiri di luar arena sebagai penonton tetapi merupakansalah satu pelaku utama dalam proses-proses transformatif. Dengan demikian, yang dituntut bukan sekadar berpartisipasi dalam pembangunan masyarakat umum tetapi lebih jauh mempunyai komitmen yang jelas berlandaskan panggilan, karya dan misinya selaku umat Allah untuk mengendalikan dan mengantisipasi arah pembangunan, serta kritis menilai segala bentuk dan cara yang digunakan untuk mencapai tujuan pembangunan Gereja, masyarakat dan negara ini.

Secara internal, Gereja juga sedang dan terus mengalami transformasi eklesiologis. Dari pengakuan diri sebagai manusia berdosa, Gereja mengalami transformasi karena kasih dan kesetiaan Allah, dan dipandu menuju realitas eksistensial yang berbeda karena karya keselamatan Kristus yang dengannya Gereja belajar menghargai kehidupan bersama Allah, sesama manusia dan alam semesta. Sebagaimana "Mesir" melambangkan perhambaan dari dosa dan "Kanaan" sebagai lambang dari harapan yang terpenuhi. Seperti yang dinyatakan oleh Dainton: ${ }^{79}$

"pengalaman di padang gurun yang berada antara kedua kutub ini, dapat digunakan sebagai lambang pengalaman kita dalam dunia yang sekarang ini, yang kita tempuh sebagai peziarah dan pengembara. Seperti telah dikatakan, konsep sebagai umat yang bergerak ini, itulah ciri yang 
sesungguhnya dari gereja Kristen: ia tidak statis, melainkan selalu menuju ke suatu tempat."

Kajian terhadap Ulangan 7:1-11 memperlihatkan bahwa perikop tersebut sebenarnya menyiratkan adanya suatu proses transformasi sosial, budaya dan agama. Penghancuran mezbahmezbah dan patung-patung, tugu-tugu dan tiang-tiang berhala secara implisit bukanlah lambang dari sikap intoleransi agama Israel terhadap kepercayaan bangsa-bangsa lain, melainkan harus diinterpretasi sebagai suatu sikap kritis dan berani menilai tradisi.

Pengunaan tata cara beribadah dalam agama Israel Kuno bukanlah seratus persen murni produk iman Israel kepada Yahweh melainkan sejarah panjang upaya pengadopsian tata cara beribadah yang umum dipakai oleh bangsa-bangsa lain. Demikian pula dengan konsep tentang "Tuhan" yang banyak berkiblat pada konsep tentang "illah" yang berlaku umum di dunia Timur Tengah Kuno. Larangan kawin-mengawin dengan pemuda atau gadis di luar Israel (endogami) juga bukan indikasi bahwa ada semacam sikap antipati terhadap masyarakat dan kebudayaan lain.

Sejumlah penelitian arkeologi menunjukkan bahwa kehidupan sosial, politik, ekonomi dan budaya masyarakat Israel Kuno tidaklah seratus persen menampilkan karakteristik bangsa yang benar-benar "murni dan khas". Hasil-hasil penelitian tersebut dengan menemukan berbagai bukti kuat bahwa masyarakat Israel telah lama hidup berdampingan dengan bangsa-bangsa lain yang berbeda agama atau kepercayaan, sistem sosial, politik dan budaya. Bahkan menunjukkan gejala-gejala sosial-budaya yang wajar,seperti proses asimilasi dan interpenetrasi antar berbagai unsur agama dan kebudayaan dengan berbagai masyarakat sekitarnya. ${ }^{80}$ Dengan demikian, kendati ada kecenderungan untuk mempertahankan kemurnian identitas komunal keagamaan tetapi masyarakat Israel tidak bisa menutup diri dari lingkungan sosialbudaya di sekitarnya. Malah, dalam konteks sosial yang heterogen 
atau majemuk itu, selalu ada stimulasi untuk membuka diri agar mengalami transformasi melalui kasih dan kesetiaan Tuhan secara total.

Tuhan ingin membawa Israel kepada suatu tatanan umat yang transformatif, dalam pengertian bahwa pemahaman iman tentang Allah yang bertindak secara nyata dalam sejarah Israel sejak nenek moyang mereka (Abraham-Ishak-Yakub) sampai pada generasi yang sekarang (Kanaan) harus menjadi bagian integral dari keyakinan dan pola kehidupan Israel. Israel harus bangkit untuk "membongkar" seluruh pola kehidupan dan tradisi-tradisi beragama dan berbudaya yang masih "tradisional", yang melihat Allah hanya sebagai allah yang kaku, diam, mati, dan tidak berkuasa apa-apa (seperti mezbah, tugu dan patung), kepada suatu pola kehidupan beriman dan berbudaya yang transformatif di mana Allah dipandang dan disembah sebagai Allah yang hidup dan menyejarah. Allah yang selalu bertindak, bergerak ke segala arah atas dasar kasih dan kesetiaan-Nya kepada manusia dan alam semesta. Tindakan Allah ini tidak dapat diatur, dikendalikan atau dibatasi oleh manusia dengan sistem-sistem peribadahan, doktrin-doktrin keagamaan dan ritus-ritus yang semu dan kerap terselubung kemunafikan.

Pada titik itu, pertanyaan yang digumuli sekarang ialah: Apa implikasi dari kerygma Ulangan 7:1-11 ini bagi Gereja sebagai umat pilihan Allah abad ini? Gumulan terhadap isu ini mesti bertolak dari sikap kritis dan lugas menyuarakan kebenaran yang memanusiakan manusia dalam konteks transformasi eklesiologis yang konstan. Gereja mesti memahami bahwa identitasnya yang sejati tidak akan terbentuk dalam status quo dan kemapanan, tetapi dalam proses penempaan diri yang kritis-dinamis. Doktrin, literatur, penafsiran Alkitab, cara berpikir, cara berkomunikasi dan jejaring persahabatannya dengan liyan, liturgi dan misiologi serta keterlibatannya di tengah masyarakat, merupakan bagianbagian sensitif yang harus terus-menerus dikaji dan diuji. Sehingga Gereja bukan hanya menjadi ecclesia via torum (Gereja 
yang berjalan) tetapi lebih jauh menampilkan identitasnya sebagai "peziarah transformatif" (transformative pilgrimage) yang selalu dalam peziarahan mencari kebenaran dengan semangat transformatif: membuka diri, belajar dari liyan, internalisasi nilai, konstruksi etika eklesiologis, mengujinya kembali dalam sejarah dan kebudayaan yang kontekstual. Demikian seterusnya hingga membentuk suatu lingkaran hermeneutika eklesiologis kontekstual.

Demikian penempaan diri seperti ini akan membawa Gereja dan Kristianitasmenuju suatu tanggung jawab etis supra-institusional. Artinya, Gereja tidak lagi hanya bertanggung jawab atas kebutuhan dan kehidupan komunitas Kristen secara eksklusif kelembagaan saja. Komitmen Gereja tidak lagi melulu komitmen komunitas Kristen tetapi menjadi komitmen kemanusiaan. Komitmen etisteologis ini melampaui sekat-sekat pemisah identitas primordial etnisitas dan keagamaan. Tanggung jawab etis supra-institusional ini tidak akan dapat dimengerti dalam kerangka kelembagaan bila kepedulian atas persoalan kemanusiaan belum menjadi agenda utama dalam diskursus berbagai komunitas lintas-iman.

Sejauh ini kepedulian akan isu-isu kemanusiaan yang selalu didengung-dengungkan masih sebatas bila memang ada ikatan kepentingan internal agama tertentu di dalamnya. ${ }^{81}$ Sumartana menanggapi sebagai berikut: ${ }^{82}$

"Kesulitan untuk menegaskan jawaban terhadap pertanyaan fundamental tersebut di atas juga terkait dengan situasi khusus dari gereja-gereja di Indonesia yang belum sepenuhnya bisa membebaskan diri dari pengaruh kuat dari masa lampaunya. Cara pandang dari kalangan misi di masa lampau telah memberikan beban yang terlalu berat sehingga tidak bisa melakukan gerak yang responsif terhadap tantangan serta desakan masalah baru dari arah masyarakat yang ada sekarang ini."

Apa yang penting untuk dikemukakan dalam konteks transformasi sosial dan pluralitas sosial-budaya masyarakat yang makin terkoneksi secara global saat ini adalah dialog kemanusiaan. Perkembangan teknologi komunikasi-informasi 
digital dengan beragam aplikasinya makin mengalienasi manusia dalam individualitas yang kompleks. Kendati tampaknya saling terhubung satu sama lain namun teknologi digital berhasil memilah dan menyekat dimensi-dimensi kemanusiaan dalam ruang-ruang virtual yang kian selfish. Dialog menghadapkan Gereja pada conditio sine qua non "mendengar-dan-bicara", kemampuan untuk menerima pesan, memahami makna pesan, dan menyampaikan kembali pesan secara baru dan kontekstual sebagai paradigma misi Ecclesia Christi. Suatu misi tanpa kesombongan dan tanpa klaim yang berlebihan - kenosis karena Gereja adalah hamba kebenaran, bukan kebenaran itu sendiri. Dialog bukanlah instrumen dari misi melainkan esensi misi. Dialog dan misi berjalan bersama ketika keduanya benarbenar merupakan langkah untuk committed dan mengabdi kepada kebenaran kasih setia Allah bagi manusia, lingkungan hidup dan alam semesta.

\section{Catatan Akhir:}

58 J. Barton, "Berbagai Pendekatan Etika dalam PL" dalam J. Rogerson (ed.), Studi PL Bagi Pemula (Jakarta: BPK Gunung Mulia, 1993), 125,127.

59 Barton, "Berbagai Pendekatan Etika dalam PL", 137.

60 Barton, "Berbagai Pendekatan Etika dalam PL", 139.

61 Arie de Kuiper, "Teologi 'Sisa' dalam PL dan Relevansinya bagi Jemaat Masa Kini" dalam F. Suleeman \& loanes Rakhmat (eds.), Masihkah Benih Tersimpan? (Jakarta: BPK Gunung Mulia, 1990), 137.

62 J. B. Banawiratma dan J. Muller, Berteologi Sosial Lintas IImu (Yogyakarta: Kanisius, 1993), 93.

63 T. B. Simatupang, Iman Kristen dan Pancasila (Jakarta: BPK Gunung Mulia, 1995), 18.

64 Politik identitas berbasis etnisitas dan keagamaan makin menguat sejak kekuatan negara versi Orde Baru mengendor pasca gerakan Reformasi 1998. Pada satu sisi, terbuka ruang demokratisasi pada semua tatanan kehidupan masyarakat yang memberikan kesempatan bagi munculnya kebebasan berekspresi. Pada sisi lain, proses demokratisasi tersebut berimplikasi pada diterjangnya etika sosial kehidupan bersama dalam realitas masyarakat majemuk seperti Indonesia. Sehingga yang muncul adalah suatu tendensi sosial-politik untuk memaksakan kepentingan "kelompok mayoritas" terhadap "kelompok minoritas". 
J. Garang, "Pluralisme dalam Kebudayaan Nasional: Sorotan Agama, Masyarakat dan Negara" (Jakarta: Buletin Akademi Leimena, 1992), 23.

Choan-Seng Song, Allah Yang Turut Menderita (Jakarta: BPK Gunung Mulia, 1993), 33-36.

67 Elizabeth K. Nottingham, Agama dan Masyarakat: Suatu Pengantar Sosiologi Agama (Jakarta: Penerbit Rajawali, 1985), 33.

68 Theo Witkamp, "Menuju Suatu Identitas Yang Terbuka". Jurnal Teologi GEMA Duta Wacana No. 47 Tahun 1994, 6.

69 Joachim Huang, "Adakah Keselamatan Di Luar Kristus?". JPZ Vol. 8 No. 1 Tahun 1993 (Yayasan Pengembangan Pelayanan Kristen Pelita Zaman), 27.

70 M. Brownlee, Pengambilan Keputusan Etis dan Faktor-faktor Di Dalamnya (Jakarta: BPK Gunung Mulia, 1993), 244; bnd. Z. Ngelow, "Hamba Kehidupan: Spiritualitas Kepedulian Sosial Kristen" dalam Eka Darmaputera (ed.), Spiritualitas Baru: Agama dan Aspirasi Rakyat (Yogyakarta: Seri DIAN II/1, 1994), 134.

71 James Barr, Fundamentalisme (Jakarta: BPK Gunung Mulia, 1994), 402.

72 Eka Darmaputera, "Spritualitas Baru dan Kepedulian terhadap Sesama: Suatu Perspektif Kristen" dalam Eka Darmaputera (ed.), Spritualitas Baru: Agama dan Aspirasi Rakyat (Yogyakarta: DIAN II/1, 1994), 57-58.

73 J. Naitbitt \& P. Aburdene, Megatrends 2000 (Yogyakarta: Binarupa Aksara 1990), 261.

74 Barr, Fundamentalisme, hal 129-130.

75 Ioanes Rakhmat, "Di Tengah Arus Fundamentalisme dalam Gereja" dalam Seotarman etal (ed.), Fundamentalisme, Agama-agama dan Teknologi (Jakarta: BPK Gunung Mulia, 1992), 28.

76 Rakhmat, "Di Tengah Arus Fundamentalisme dalam Gereja", 30.

77 Budi Susilo, "Mentalitas dalam Pembangunan Masyarakat Modern" dalam J. Mardimin (ed.), Jangan Tangisi Tradisi: Transformasi Budaya Menuju Masyarakat Indonesia Modern (Yogyakarta: Kanisius, 1994), 63-64.

78 Susilo, "Mentalitas dalam Pembangunan Masyarakat Modern", 65.

79 M. B. Dainton, Gereja Milik Siapa: Konteks Umat Allah Masa Kini di Indonesia (Jakarta: YKBK/OMF, 1994), 120.

80 Anton Wessels, "Biblical Presupposition For and Against Syncretism" dalam Jerald Gort etal (ed.), Dialogue and Syncretism (Grand Rapids: WB Eerdmans, 1989), 5455.

81 Th. Sumartana, "Eksperimentasi Demokratisasi Dari Agama-Agama" dalam M. Imam Aziz et.al (ed), "Agama, Demokrasi dan Keadilan" (Gramedia Jakarta 1993), hal 60

82 Th. Sumartana, "Misi Kristiani: Kristenisasi Atau Humanisasi?" (Litbang PGI-Suara Pembaruan, Jakarta, 24 Mei 1994), hal 1 


\section{Bab 4 Simpul}

Denyelidikan dan interpretasi terhadap Kitab Ulangan 7:111 membuka kemungkinan-kemungkinan baru dalam membaca dan memaknai teks-teks keagamaan yang secara harfiah menampilkan suatu semangat keagamaan yang eksklusif dan triumfalistik. Pembacaan secara dangkal terhadap teksteks semacam itu dapat menjadi amunisi ideologis yang memperkeras sikap beriman yang sempit dan jumud. Kajian terhadap teks Ulangan 7:1-11 ini merupakan upaya kecil untuk menghadirkan perspektif alternatif memahami teks ersebut sekaligus merumuskan etika sosial kristiani yang terinspirasi dari interpretasi kontekstual atasnya. Dialektika teks-konteks secara konstan akan selalu menantang kecenderungan memberhalakan teks-teks keagamaan dengan asumsi-asumsi universalisme, yaitu bahwa teks-teks keagamaan semacam itu hanya dibaca apa adanya dan dipaksakan untuk diterapkan dalam semua konteks kehidupan manusia.

Asumsi-asumsi universalisme dalam beragama merupakan salah satu isu problematik dalam relasi antar agama. Setiap agama memiliki pendakuan kebenaran teologis atau imaniah masingmasing sebagai karakteristik keberagamaan, terutama pada agama-agama misioner. Pendakuan kebenaran teologis tersebut 
didasarkan pada penguatan doktrin-doktrin yang menjadi pilar bagi pengawetan dan kontinuasi setiap institusi agama. Dalam konteks masyarakat majemuk, pendakuan kebenaran teologis setiap agama berada dalam dialektika, bahkan konfrontasi, satu terhadap yang lain. Secara positif, itu bisa mengarah pada dialog antar iman untuk saling memperkaya tradisi beriman setiap agama. Namun, secara negatif, pendakuan kebenaran teologis setiap agama dalam konteks masyarakat majemuk juga berpotensi memicu ketegangan, polemik doktrinal dan konflik antar pemeluk agama. Oleh karena itu, salah satu faktor penting dalam pengelolaan kehidupan bersama antar umat beragama adalah melalui peninjauan kembali secara interpretatif teks-teks keagamaan yang bernuansa eksklusif, intoleran dan triumfalistik. Peninjauan ini adalah upaya mendekonstruksi teks-teks keagamaan agar tetap dapat dibaca secara bermakna bagi orangorang beragama yang hidup dalam ruang dan waktu yang berbeda dengan konteks ketika teks-teks tersebut diproduksi awalnya.

Penelusuran terhadap konsep "Umat Pilihan Allah" sebagaimana termuat dalam narasi teks Ulangan 7:1-11 ini kemudian mengerucut pada beberapa simpul hipotetik yang pada gilirannya terbuka untuk dikritisi kembali oleh para peneliti lain, sebagai berikut:

a. Konsepsi "Umat Pilihan Allah" yang dimunculkan oleh penulis Deuterenomi merupakan suatu ketegasan sikap yang diambil untuk menetapkan dan memantapkan jati diri dan identitas umat Israel di tengah pergolakan situasi sosial dan politik pada masanya. Krisis identitas yang dialami oleh umat Israel ini disebabkan oleh beratnya tekanan penderitaan akibat penindasan yang dilakukan oleh bangsa-bangsa lain yang lebih kuat, yang dalam konteks Deuteronomi diwakili oleh Kerajaan Asyur.

b. Goncangan sistem dan struktur kehidupan di bidang sosial dan politik ini juga mempunyai ekses yang cukup besar bagi kehidupan keagamaan dan iman Israel. Umat 
Israel mengalami krisis identitas iman dan terperangkap dalam jaringan sinkretisme yang menyebabkan lunturnya kesetiaan kepada Yahweh karena tercampur-baur dengan kesetiaan serta penyembahan kepada Baal. Oleh karena itu, Deuteronomi mengangkat kembali konsep "Umat Pilihan Allah" sebagai suatu dorongan bagi perjuangan Israel memantapkan identitas dan eksistensi mereka selaku umat Allah yang terikat perjanjian dengan Yahweh sejak zaman leluhur mereka.

c. Ikatan perjanjian dan tuntutan kesetiaan kepada Yahweh ini mesti terus-menerus menjadi landasan bagi iman Israel. Dengan demikian, segala unsur asing yang hendak merusak dan menghancurkan ikatan tersebut harus disingkirkan agar Yahweh tetap menjadi satu-satunya TUHAN dan ALLAH bagi Israel.

d. Kini konsepsi "Umat Pilihan Allah" juga dipakai oleh Gereja sebagai perwujudan identitas dan eksistensi dirinya. Namun di tengah tantangan pluralisme agama dan kenyataan multikulturalisme masa kini konsep "umat pilihan Allah" mendapat tekanan yang sangat kuat. Kendati bertujuan untuk menampilkan eksistensi dan identitasnya secara nyata tetapi reaksi-reaksi yang muncul lebih condong mengacu pada suatu sikap beragama yang ekslusif bahkan pejoratif dalam menilai hubungannya dengan agama-agama lain.

e. Akan tetapi, pada sisi yang lain, pluralisme agama juga menantang Gereja untuk mencari sosok dan identitasnya secara positif dengan membuka diri berdasarkan kasih dan kerelaan berkorban bagi sesama manusia tanpa terkecuali. Suatu identitas yang terbuka dalam perjumpaannya dengan berbagai kelompok dan tradisi agama di Indonesia sebagai respons atas kasih dan kesetiaan Allah yang universal.

f. Dengan demikian, Gereja, yang secara teologis mengaku sebagai umat pilihan Allah, mengemban tanggung jawab 
eksistensial atas kehidupan liyan (manusia dan alam semesta) sebagai wujud dan hakekat keterpanggilannya di dalam dunia milik Allah. Ini adalah tanggung jawab yang melampaui batas-batas kelembagaan, dengan lingkup kemanusiaan yang universal. Dengannya pula, tanggung jawab ini turut melibatkan seluruh umat beragama di Indonesia untuk bersama-sama menjawab dan mengatasi berbagai permasalahan kemanusiaan yang timbul sebagai salah satu konsekuensi logis pembangunan dan/atau transformasi sosial-budaya. Dengan lain perkataan, Gereja yang secara teologis mengaku sebagai umat pilihan Allah bersama-sama dengan agama-agama lain mesti memperkuat kepekaan untuk kritis dalam menilai arah pembangunan dan transformasi sosial-budaya agar tetap menjunjung tinggi harkat dan martabat manusia.

g. Dialog kehidupan antarumat beragama dinilai sebagai konstruksi sosiologis-teologis yang paling strategis untuk membangun relasi antarumat beragama di Indonesia. Dialog kehidupan merupakan perluasan konseptual dan praksis dari dialog konvensional antar lembaga agama yang pada kenyataannya hanya melibatkan para tokoh/ elite dari berbagai institusi keagamaan di Indonesia. Dialog kehidupan ini tidak lagi diwacanakan secara teoretikkonseptual dalam ruang-ruang seminar atau ruang-ruang kuliah tetapi diproyeksikan sebagai praksis keberagamaan dalam arena kehidupan keseharian masyarakat yang terdiri dari atas berbagai unsur identitas sosial-politik dan agama. Hanya melalui dialog kehidupan keseharian ini masyarakat belajar dan merumuskan sendiri apa yang menjadi dimensi determinan dalam mempertahankan komunikasi lintasagama dengan kesadaran akan peran setiap agama secara mutual untuk menopang aktivitas sehari-hari sebagai masyarakat kebanyakan. 


\section{Kepustakaan}

Alt, Albercht, Essays on Old Testament and Religion. Basil Blackwell, New York 1966.

Aziz, M. Iman dkk (ed.), Agama, Demokrasi dan Keadilan. Gramedia, Jakarta 1993.

Baker, David L., Satu Alkitab Dua Perjanjian. BPK Gunung Mulia, Jakarta 1993.

Banawiratma, J. B., SJ dan J. Muller, SJ, Berteologi Sosial Lintas Ilmu. Kanisius, Yogyakarta 1993.

Banawiratma, J. B., SJ (ed.), Kemiskinan dan Pembebasan. Kanisius, Yogyakarta 1987.

Barr, James, Fundamentalisme. BPK Gunung Mulia, Jakarta 1994.

Barth, C., Theologia PL 1. BPK Gunung Mulia, Jakarta 1990. , Theologia PL 2. BPK Gunung Mulia, Jakarta 1991.

Berkhof, H. dan I. H. Enklaar, Sejarah Gereja. BPK Gunung Mulia, Jakarta 1990.

Botterweck, G. Johannes and Helmer Ringgren, Theological Dictionary of the Old Testament. Vol. II.W. B. Eerdmans, Grand Rapids 1975.

Bright, John, A History of Israel. SCM Press, London 1960. 
Brownlee, Malcolm, Tugas Manusia dalam Dunia Milik Tuhan. BPK Gunung Mulia, Jakarta 1993.

, Pengambilan Keputusan Etis. BPK Gunung Mulia, Jakarta 1993.

Bruce, F.F., Israel and the Nations. Paternoster Press, United Kingdom 1963.

(ed.), Ensiklopedia Alkitab Masa Kini Jilid 1. YKBK/ OMG, Jakarta 1962.

Cairns, I. J., Tafsiran Alkitab: Kitab Ulangan 1-11. BPK Gunung Mulia, Jakarta 1994.

Charpentier, Etienne, Bagaimana Membaca Perjanjian Lama? BPK Gunung Mulia, Jakarta 1989.

Clements, R. E., God's Chosen People. SCM Press, London 1969.

Coward, Harold, Pluralisme: Tantangan bagi Agama-agama. Kanisius, Yogyakarta 1989.

Dainton, M. B., Gereja, Milik Siapa? YKBK, Jakarta 1994.

Darmawijaya, St., Pr., Warta Nabi Abad VIII.Kanisius, Yogyakarta 1990.

Davidson, Benjamin, The Analytical Hebrew and Chaldee Lexicon. Zondervan Publishing House, Amsterdam 1970.

De Jonge, Chr., Gereja Mencari Jawab. BPK Gunung Mulia, Jakarta1994.

De Vaux, Roland, Ancient Israel: It's Life and Institution. SCM Press, London1961.

Darmaputera,Eka (ed.), Konteks Berteologi di Indonesia. BPK GunungMulia, Jakarta 1991.

Pancasila: Identitas dan Modernitas. BPK GunungMulia, Jakarta 1991. 
Garang, J., Pluralisme dalam Kebudayaan Nasional: Sorotan Agama, Masyarakat dan Negara. Buletin Akademi Leimena, Jakarta 1992.

Gort, Jerald, etal (ed.), Dialogue and Syncretism. W. B. Eerdmans: Grand Rapids, 1982.

Gottwald, Norman K., The Tribes of Yahweh. Orbis Books, New York 1979.

Green, Jay (ed.), The Interlinear Hebrew/Greek English Vol.I. Associated Publishers and Authors, Indiana 1979.

Hinson, David F., Sejarah Israel Pada Zaman Alkitab. BPK Gunung Mulia, Jakarta 1991.

Huang, Joachim, "Adakah Keselamatan di Luar Kristus?". Jurnal Pelita Zaman Vol. 8 No. 1 - Mei 1993.

Johnson, D.P., Teori Sosiologi Klasik dan Modern Jilid 1. Gramedia, Jakarta 1986.

Küng, Hans, On Being A Christian. Collins, London 1977.

Knitter, Paul F., No Other Name? SCM Press, London 1985.

Lohfink, Gerhard, Jesus and Community. SPCK, London 1985.

Mardimin, Johannes (ed.), Jangan Tangisi Tradisi: Transformasi Budaya Menuju Masyarakat Indonesia Modern.Kanisius, Yogyakarta 1994.

Mayes A.D.H., Deuteronomy. W. B. Eerdmans \& Marshall, Morgan \& Scott, London 1979.

McConville, J.G., Law and Theology in Deuteronomy. JSOT Press, Shefflield 1984.

Naisbitt, John \& P. Aburdene, Megatrends 200o. Bina Rupa Aksara, Yogyakarta 1990.

Napel, Henk Ten, Kamus Teologi Inggris-Indonesia. BPK Gunung Mulia, Jakarta 1994. 
Nicholson, E.W., Deuteronomy and Tradition. Westminster Press, Philadelphia 1967.

Nottingham, Elizabeth, Agama dan Masyarakat: Suatu Pengantar Sosiologi Agama. CV Rajawali, Jakarta 1985.

Pattiasina, J.M. dan W. Sairin (eds.), Gerakan Oikoumene: Tegar Mekar di Bumi Pancasila. BPK Gunung Mulia, Jakarta 1993.

Pyne, David F., Deuteronomy. The Saint Andrew Press Edinburgh and the Westminsters Press Philadelphia 1985.

Rogerson, John (ed.), Studi PL Bagi Pemula. BPK Gunung Mulia, Jakarta 1993.

Richardson, Alan, An Introduction to the Theology of New Testament. SCM Press, London: 1969.

Sandmel, Samuel, The Hebrew Scripture. Oxford University Press, New York 1978.

Schmidt, Werner H., Introduction to the Old Testament. SCM Press, London 1984.

Sidjabat, W. B., Religious Tolerance and the Christian Faith. BPK Gunung Mulia, Jakarta 1982.

Simatupang, T. B., Iman Kristen dan Pancasila. BPK Gunung Mulia, Jakarta 1995 .

Soetarman dkk (eds.), Fundamentalisme, Agama-agama dan Teknologi. BPK Gunung Mulia, Jakarta 1992.

Soedjito, Transformasi Sosial menuju Masyarakat Industri. Tiara Wacana, Yogyakarta 1986.

Song, Choan-Seng, Allah Yang Turut Menderita. BPK Gunung Mulia, Jakarta 1993.

Snaith, Norman H., Distinctive Ideas of the Old Testament. Westminster Press, Philadelphia 1944. 
Suharyo, I., Pr., Mengenal Allah dalam Perjanjian Lama. Kanisius, Yogyakarta 1993.

Suleeman, F. dan I. Rakhmat, Masihkan Benih Tersimpan? BPK Gunung Mulia, Jakarta 1990.

Sumartana, Th., Mission at the Crossroad. BPK Gunung Mulia, Jakarta 1993.

etal (eds.), Dialog: Kritik dan Identitas Agama. DIAN/ INTERFIDEI I/1, Yogyakarta 1993.

etal (eds.), Spiritualitas Baru: Agama dan Aspirasi Rakyat. DIAN/INTERFIDEI II/1, Yogyakarta 1994.

et.al. (eds.), Terbit Sepucuk Taruk: Teologi Kehidupan. P3M-STTJ dan BALITBANG PGI, Jakarta 1993.

"Misi Kristiani: Kristenisasi atau Humanisasi?" BALITBANG PGI-Suara Pembaruan, Jakarta 24 Mei 1994.

Tanya, Victor I., Spiritualitas, Pluralitas dan Pembangunan di Indonesia. BPK Gunung Mulia, Jakarta 1994.

Van Leeuwen, Arend Th., Agama Kristen dalam Sejarah Dunia. BPK Gunung Mulia, Jakarta 1990.

Verkuyl, J., Etika Kristen: Bagian Umum. BPK Gunung Mulia, Jakarta 1991.

Von Rad, Gerhard, Deuteronomy: A Commentary. SCM Press, London 1966.

, Old Testament Theology Vol. I. SCM Press, London 1962.

Witkamp, Theo, "Menuju Suatu Identitas Yang Terbuka". Jurnal Teologi GEMA No. 47 UKDW Press, Yogyakarta 1994.

Wright, G. Ernest, The Challenge of Israel's Faith. The University of Chicago Press, Chicago 1943. 
Wright, Christopher, Hidup sebagai Umat Allah: Etika Perjanjian Lama. BPK Gunung Mulia, Jakarta 1993.

Yewangoe, A. A., Theologia Crucis di Asia. BPK Gunung Mulia, Jakarta 1993. 


\section{Tentang Penulis}

Steve Gerardo Christoffel Gaspersz adalah Pendeta Gereja Protestan Maluku (GPM) yang ditugaskan sebagai dosen tetap pada Fakultas Teologi dan Program Pascasarjana Universitas Kristen Indonesia Maluku (UKIM) di Ambon. Studi dasar teologi ditempuh pada Fakultas Teologi UKIM; Magister Sains (M.Si.) dari Program Pascasarjana Teologi "Injil dan Adat" (kemudian berubah: Agama dan Kebudayaan) UKIM dan Program Magister Sosiologi Agama (MSA) UKSW Salatiga; Master of Arts (M.A.) in Theology dari Faculty of Theology, Vrije Universiteit Amsterdam; Ph.D. in Inter-religious Studies dari Indonesian Consortium for Religious Studies (ICRS) - konsorsium tiga universitas di Yogyakarta (UGM/UKDW/UIN SunanKalijaga), dengan beasiswa penuh dari United Board for Higher Education. Tahun 2010 mengikuti shortcourse pada Calvin Theological Seminary, Grand Rapids, Michigan - Amerika Serikat. Mendapat kesempatan menjadi visiting scholar pada tahun 2013 melalui program Institute for Advanced Study of Asian Cultures and Theologies (IASACT) United Board for Higher Education di Chung Chi College, Chinese University of Hong Kong. Tahun 2015 menjadi visiting scholar pada South East Asia Program (SEAP), Cornell University, Ithaca, New York Amerika Serikat. Menikah dengan Pdt. Dr. Nancy N. Souisa, M.Si. dan dikaruniai dua putra-putri: Kainalu dan Kailani. Penulis buku Iman Tidak Pernah Amin: Menjadi Kristen dan Menjadi Indonesia (BPK Gunung Mulia Jakarta 2009) dan sejumlah artikel bab pada beberapa buku antologi. 
